\title{
46. BIOCHRONOLOGIC AND MAGNETOCHRONOLOGIC SYNTHESIS OF LEG 119 SEDIMENTS FROM THE KERGUELEN PLATEAU AND PRYDZ BAY, ANTARCTICA ${ }^{1}$
}

\author{
John A. Barron, ${ }^{2}$ Jack G. Baldauf, ${ }^{3}$ Enriqueta Barrera, ${ }^{4}$ Jean-Pierre Caulet, ${ }^{5}$ Brian T. Huber, ${ }^{6}$ Barbara H. Keating, ${ }^{7}$ \\ David Lazarus, ${ }^{8}$ Hideo Sakai, ${ }^{9}$ Hans R. Thierstein,${ }^{8}$ and Wuchang Wei ${ }^{10}$
}

\begin{abstract}
This paper summarizes the biostratigraphy and magnetostratigraphy of the 11 sites drilled on the Kerguelen Plateau and in Prydz Bay, Antarctica, during ODP Leg 119. Excellent magnetobiochronologic reference sections were obtained at deep-water Sites 745 and $746(0-10 \mathrm{Ma})$ and at intermediate depth Site $744(0-39 \mathrm{Ma})$ on the southern Kerguelen Plateau. Site 738, an intermediate depth companion site for Site 744 , contains a nearly complete lowermost Oligocene to Turonian carbonate section including a continuous sequence across the Cretaceous/Tertiary boundary. Northern Kerguelen Sites 736 and 737 (ca. $600 \mathrm{~m}$ water depth) constitute a composite middle Eocene to Quaternary reference section near the present-day Antarctic Polar Front.

Biostratigraphic control is limited in Prydz Bay Sites 739-743. Glacial sequences cored on the continental shelf at Sites 739 and 742 appear to form a composite record, possibly from the uppermost middle Eocene to the Quaternary; the entire upper Oligocene and most of the Miocene, however, are removed at an unconformity. Preglacial sediments at Site 741 contain Early Cretaceous pollen and spores, but the red beds cored at Site 740 are unfossiliferous. Poorly-fossiliferous glacial sediments of probable Quaternary age were sampled on the upper slope at Site 743 .

A magnetobiochronologic time scale is presented for the Late Cretaceous and Cenozoic of the Southern Ocean based on previous studies and the results of Leg 119 studies.
\end{abstract}

\section{INTRODUCTION}

Ocean Drilling Program (ODP) Leg 119 completed 22 holes at 11 sites in the Southern Ocean on the Kerguelen Plateau (Sites 736-738 and 744-746) and in Prydz Bay, east Antarctica (Sites 739-743) (Table 1 and Fig. 1). The sections cored on the Kerguelen Plateau form a latitudinal transect of mostly pelagic sediments extending from $49^{\circ} 24.12^{\prime} \mathrm{S}$ (Site 736 ) to $62^{\circ} 42.54^{\prime} \mathrm{S}$ (Site 738). Sediments recovered at the six Kerguelen Plateau sites make up three composite sections. Sites 736 and 737 lie near the present-day Antarctic Polar Front at relatively shallow water depths (639.5 and $574.5 \mathrm{~m}$, respectively), and drilling at these sites cored a composite section of upper middle Eocene to Quaternary biosiliceous and calcareous sediment containing variable amounts of terrigenous and volcanic debris (Barron, Larsen, et al., 1989). A Turonian to Quaternary composite section of mostly calcareous chalks and ooze, mixed diatomaceous-nannofossil ooze, and diatomaceous ooze was recovered at Sites 738 and 744, which lie at intermediate water depths (2263 and 2317 $\mathrm{m}$, respectively) on the southern part of the Kerguelen Plateau. The upper Miocene to Quaternary section cored at Sites 745 and 746 (4093 and $4070 \mathrm{~m}$, respective water depths) on the eastern flank of the Kerguelen Plateau constitutes a deep-water reference section for the last $10 \mathrm{~m}$.y.

\footnotetext{
${ }^{1}$ Barron, J., Larsen, B., et al., 1991. Proc. ODP, Sci. Results, 119: College Station, TX (Ocean Drilling Program).

2 U.S. Geological Survey, Menlo Park, CA 94025, U.S.A.

3 Ocean Drilling Program, 1000 Discovery Drive, College Station, TX $77845-$ 95470, U.S.A.

4 Department of Geological Sciences, The University of Michigan, Ann Arbor, MI 48103, U.S.A.

5 Laboratoire de Géologie, Muséum, 43 Rue Buffon, Paris 75005, France.

6 Department of Paleobiology, NHB-121, Smithsonian Institution, Washington, D.C. 20560, U.S.A.

${ }^{7}$ Hawaii Institute of Geophysics, University of Hawaii, Honolulu, HI 96822 , U.S.A.

${ }^{8}$ Geologisches Institut, ETH-Zentrum, CH-8092 Zurich, Switzerland.

9 Department of Earth Sciences, Toyama University, Toyama City 930, Japan. U.S.A.

10 Department of Geology, Florida State University, Tallahassee, FL 32306,
}

Table 1. Location and water depth of holes drilled during Leg 119.

\begin{tabular}{|c|c|c|}
\hline Hole & $\begin{array}{l}\text { Latitude/ } \\
\text { longitude }\end{array}$ & $\begin{array}{c}\text { Water } \\
\text { depth } \\
\text { (m) }\end{array}$ \\
\hline $736 \mathrm{~A}$ & $49.40^{\circ} \mathrm{S} / 71.66^{\prime} \mathrm{E}$ & 629.0 \\
\hline $736 \mathrm{~B}$ & $49.40^{\circ} \mathrm{S} / 71.66^{\prime} \mathrm{E}$ & 628.1 \\
\hline $736 \mathrm{C}$ & $49.40^{\circ} \mathrm{S} / 71.66^{\prime} \mathrm{E}$ & 629.0 \\
\hline $737 \mathrm{~A}$ & $50.23^{\circ} \mathrm{S} / 73.03^{\prime} \mathrm{E}$ & 564. \\
\hline 737B & $50.23^{\circ} \mathrm{S} / 73.03^{\prime} \mathrm{E}$ & 564.0 \\
\hline $738 \mathrm{~A}$ & $62.71^{\circ} \mathrm{S} / 82.78^{\prime} \mathrm{E}$ & 2252.7 \\
\hline $738 \mathrm{~B}$ & $62.71^{\circ} \mathrm{S} / 82.79^{\prime} \mathrm{E}$ & 2252.5 \\
\hline $738 \mathrm{C}$ & $62.71^{\circ} \mathrm{S} / 82.79^{\prime} \mathrm{E}$ & 2252.5 \\
\hline 739A & $67.28^{\circ} \mathrm{S} / 71.77^{\prime} \mathrm{E}$ & 412.4 \\
\hline $739 \mathrm{~B}$ & $67.28^{\circ} \mathrm{S} / 71.77^{\prime} \mathrm{E}$ & 412.4 \\
\hline $739 \mathrm{C}$ & $67.28^{\circ} \mathrm{S} / 71.77^{\prime} \mathrm{E}$ & 412.4 \\
\hline $740 \mathrm{~A}$ & $68.76^{\circ} \mathrm{S} / 76.68^{\prime} \mathrm{E}$ & 807.5 \\
\hline $740 \mathrm{~B}$ & $69.76^{\circ} \mathrm{S} / 76.68^{\prime} \mathrm{E}$ & 814.4 \\
\hline $741 \mathrm{~A}$ & $68.38^{\circ} \mathrm{S} / 76.38^{\prime} \mathrm{E}$ & 551. \\
\hline $742 \mathrm{~A}$ & $67.55^{\circ} \mathrm{S} / 75.41^{\prime} \mathrm{E}$ & 415.7 \\
\hline $743 \mathrm{~A}$ & $66.92^{\circ} \mathrm{S} / 74.69^{\prime} \mathrm{E}$ & 988.7 \\
\hline $744 \mathrm{~A}$ & $61.58^{\circ} \mathrm{S} / 80.59^{\prime} \mathrm{E}$ & 2307.2 \\
\hline 744B & $61.56^{\circ} \mathrm{S} / 80.59^{\prime} \mathrm{E}$ & 2306.5 \\
\hline $744 \mathrm{C}$ & $61.58^{\circ} \mathrm{S} / 80.59^{\prime} \mathrm{E}$ & 2308.0 \\
\hline $745 \mathrm{~A}$ & $59.59^{\circ} \mathrm{S} / 85.85^{\prime} \mathrm{E}$ & 4093.0 \\
\hline $745 B$ & $59.59^{\circ} \mathrm{S} / 85.85^{\prime} \mathrm{E}$ & 4082. \\
\hline $746 \mathrm{~A}$ & $59.57^{\circ} \mathrm{S} / 85.87^{\prime} \mathrm{E}$ & 4059.5 \\
\hline
\end{tabular}

The sections cored in Prydz Bay form a 150-km-long transect across the continental shelf (Sites 739-742) with an additional site (Site 743) on the upper slope in $999 \mathrm{~m}$ of water. Biostratigraphic control of these mostly glacial and nonmarine sediments is generally poor and will not be discussed in the same detail as that of the Kerguelen Plateau sites.

\section{MAGNETOBIOCHRONOLOGIC FRAMEWORK}

The establishment of a magnetobiochronologic framework for the Southern Ocean is an ongoing process, as Ocean Drilling Program (ODP) legs to antarctic and subantarctic waters collect more and more sediment sections with improved magnetostra- 


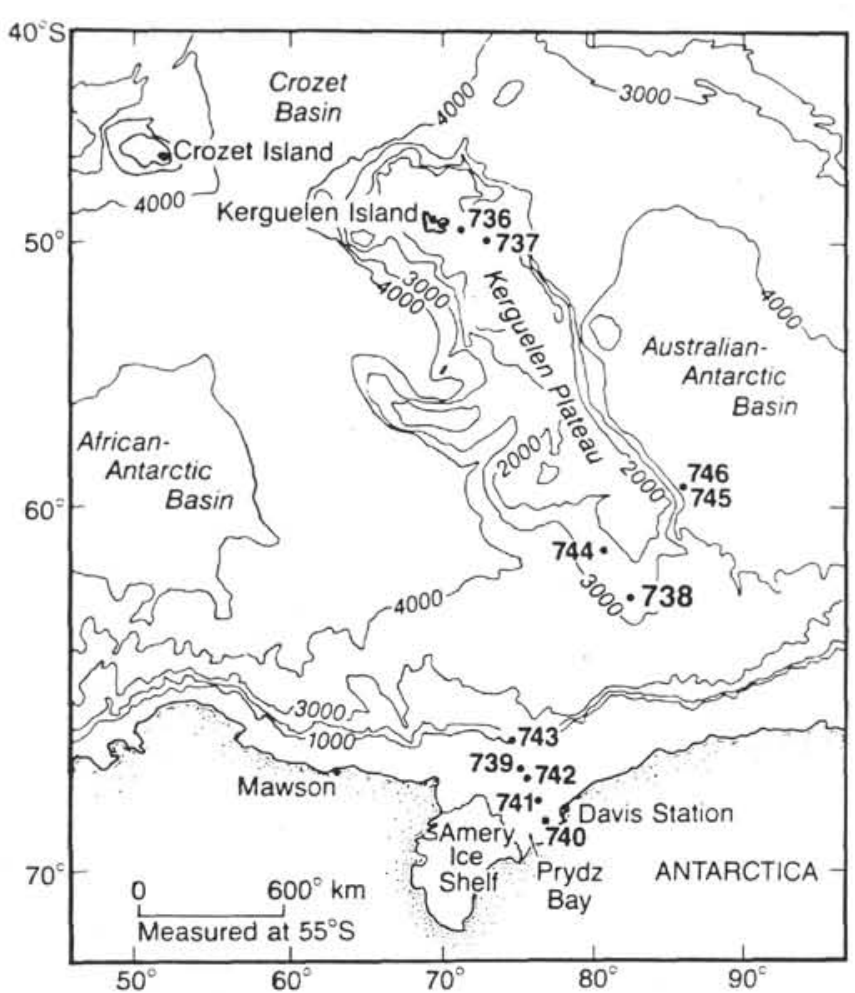

Figure 1. Location of Leg 119 sites on the Kerguelen Plateau and in Prydz Bay, Antarctica. Contours in meters.

tigraphy that can be integrated with previous results from the Deep Sea Drilling Project (DSDP). Magnetostratigraphy is essential for calibration of high-latitude microfossil datum levels for the Mesozoic and Cenozoic, most of which are either substantially diachronous from tropical datum levels or involve endemic antarctic taxa.

ODP Legs 113 and 114 have provided excellent reference sections that are well-constrained by magnetostratigraphy, which together with similar material sampled during ODP Legs 119 and 120 will allow the establishment and refinement of biochronologies for the Southern Ocean. The biostratigraphic syntheses of Antarctic ODP Leg 113 by Thomas et al. (1990) and Gersonde et al. (1990) proposed a biochronologic framework which can be tested and further refined by the studies of microfossils, magnetostratigraphy, and strontium isotopes of Leg 119 material. Similar biostratigraphic syntheses from Leg 114 were unfortunately not available at the time of writing of this compilation.

The planktonic microfossil biostratigraphy (planktonic foraminifers, calcareous nannofossils, radiolarians, and diatoms), magnetostratigraphy, and strontium isotope stratigraphy of the Leg 119 sections collected from the Kerguelen Plateau and Prydz Bay, Antarctica, are summarized in the following sections. The age models developed for each of the Kerguelen Plateau sites allow construction of age vs. depth plots and refinement of the existing magnetobiochronologic framework for the Upper Cretaceous and Cenozoic of the Southern Ocean.

Biostratigraphic and magnetostratigraphic studies of Leg 119 sediments utilize the geomagnetic polarity time scale of Berggren et al. (1985a, b, c) and Aubry et al. (1988). The epoch/ stage boundaries used during Leg 119 studies are as follows:

1. Pliocene/Pleistocene boundary

$1.6 \mathrm{Ma}$

2. early/late Pliocene boundary

3.4 Ma

3. Miocene/Pliocene boundary
4. middle/late Miocene boundary

5. early/middle Miocene boundary

$10.4 \mathrm{Ma}$

6. Oligocene/Miocene boundary

7. early/late Oligocene boundary

8. Eocene/Oligocene boundary

9. middle/late Eocene boundary

10. early/middle Eocene boundary

11. Paleocene/Eocene boundary

12. early/late Paleocene boundary

13. Cretaceous/Tertiary boundary

14. Campanian/Maestrichtian boundary

$16.5 \mathrm{Ma}$

$23.7 \mathrm{Ma}$

$30.0 \mathrm{Ma}$

$36.6 \mathrm{Ma}$

$40.0 \mathrm{Ma}$

$52.0 \mathrm{Ma}$

$57.8 \mathrm{Ma}$

$62.3 \mathrm{Ma}$

$66.4 \mathrm{Ma}$

$75.4 \mathrm{Ma}$

The pre-Maestrichtian section recovered at Site 738 will not be discussed in detail here, and the reader is referred to Wei and Thierstein (this volume) and Barron, Larsen, et al. (1989).

\section{Calcareous Nannofossils}

The biostratigraphic zonations used in Leg 119 studies (Wei and Thierstein, this volume) are those proposed by Okada and Bukry (1980) for the Cenozoic and Roth (1978) for the Cretaceous, complemented by the high-latitude Southern Ocean zonation proposed by Wei and Wise (1990). A new zonation has been proposed for the Danian (lower Paleocene) at Site 738 (Wei and Pospichal, this volume) (Table 2). All these zones are tied to the geomagnetic reversal time scale in Figure 2 based on studies by Berggren et al. (1985a, b, c), Aubry et al. (1988), and Wei and Wise (1990). For the late Mesozoic, the calibrations are based on interpolations of nannofossil events within paleomagnetic chrons using sediment thicknesses in the Bottaccione section near Gubbio, as given by Monechi and Thierstein (1985).

\section{Planktonic Foraminifers}

Many important marker species used in standard low- to middle-latitude, planktonic foraminifer zonal schemes are absent from the high southern latitudes, particularly within the Neogene. Stott and Kennett (1990) proposed a new biostratigraphic zonation for the Antarctic Paleogene, which is followed by Huber (this volume) with some modifications (Table 2). Whenever possible tropical planktonic foraminiferal zones have also been recognized. These include those of Caron (1985) for the Late Cretaceous, those of Berggren and Miller (1988) for the Paleogene, and those of Blow (1979) for the early Miocene. The Austral Province zonal scheme of Huber (1990) is used for the Maestrichtian. Correlation of these planktonic foraminiferal zones to the geomagnetic polarity time scale follows these studies with some modification as suggested by Thomas et al. (1990) and Huber (this volume) (Fig. 2).

\section{Radiolarians}

The Antarctic/Subantarctic radiolarian zonation, proposed by Chen (1975) and modified by Weaver (1983) and Caulet (1985, 1986), has been used by Caulet (this volume) to zone $\mathrm{Ne}-$ ogene sediments (Table 2). Lazarus (in press) has applied the ODP 113 radiolarian zonations of Lazarus (1990) and Abelmann (1990) to the Miocene sections of Sites 744-746, and he added three new zones, the Amphymenium challengerae, Acrosphaera labrata, and Siphonosphaera vesuvius zones, for the late Miocene (Table 2). Calibration of these zones to the geomagnetic polarity time scale (Fig. 2) follows previous studies (Caulet, this volume; Lazarus, 1990; Abelmann, 1990) with further refinement suggested by correlation of radiolarian stratigraphy with paleomagnetically-dated sequences collected at Sites 744-746 (Caulet, this volume; Lazarus, in press).

No local detailed biostratigraphic scales are proposed for the Paleogene and Cretaceous because (1) radiolarian zonations for the Oligocene, Eocene, Paleocene, and Cretaceous have not been established for high latitudes and (2) most Cretaceous to 
A

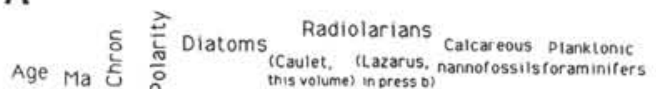

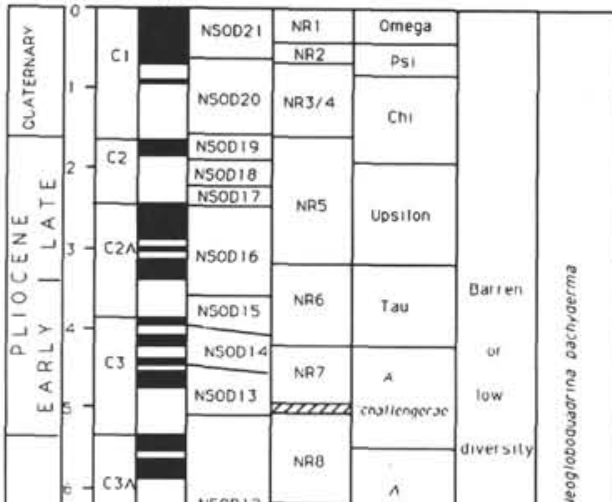

B

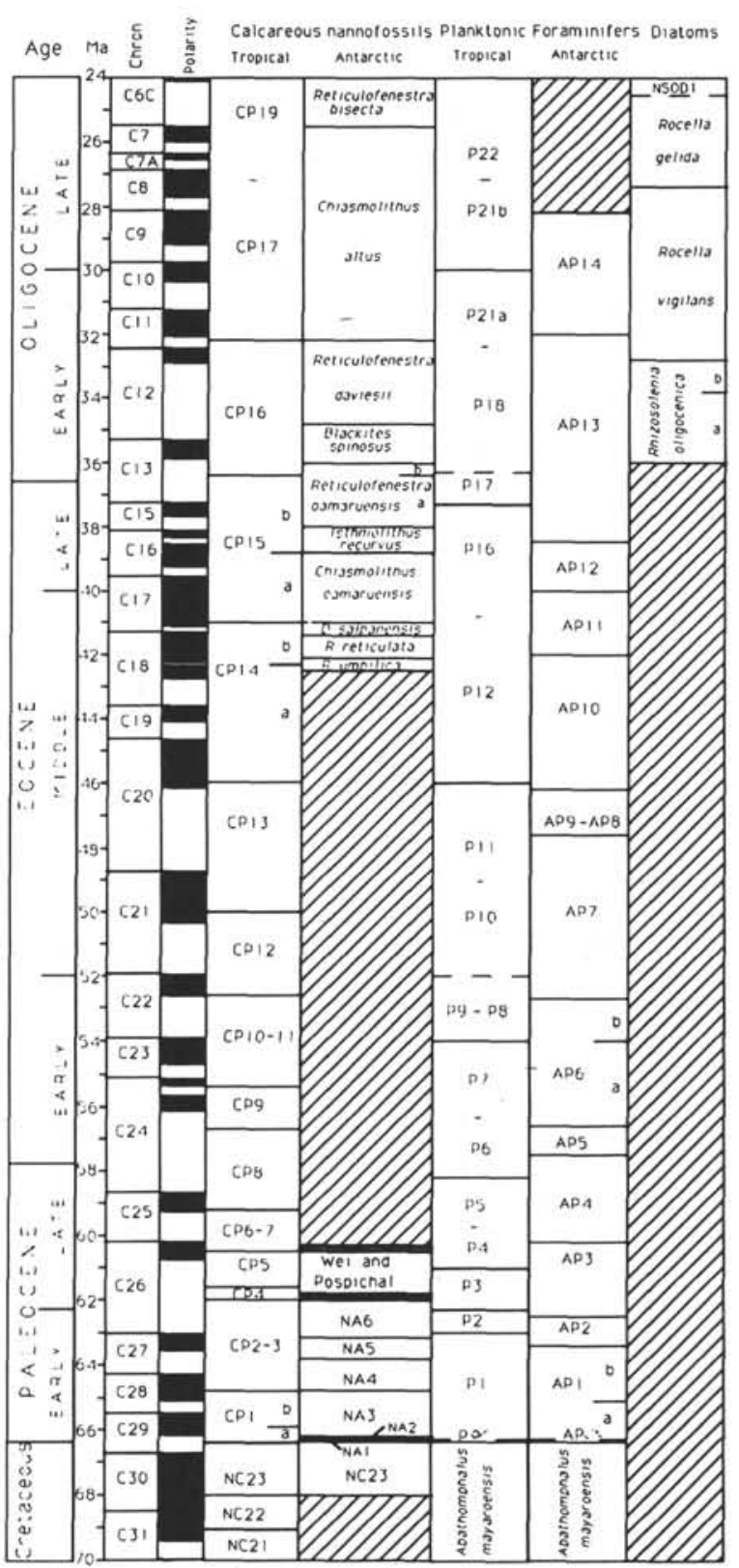

Figure 2. Magnetobiochronologic framework for the Late Cretaceous and Cenozoic adopted for Leg 119 studies. Geomagnetic polarity time scale after Berggren et al. (1985a, b, c) with magnetic polarity chrons of Tauxe et al. (1984). Microfossil zones employed: diatoms (Baldauf and Barron, this volume); radiolarians (Caulet, this volume; Lazarus, in press), calcareous nannofossils (Wei and Thierstein, this volume; and Wei and Pospichal, this volume for Paleocene); planktonic foraminifers (Huber, this volume [two reports]). (See text and Table 2 for details of zonations.) Diagonal lines shown for intervals of uncertainty or lacking study. 
Table 2. New biostratigraphic zones used in Leg 119 studies.

Calcareous nannofossils zones (Wei and Pospichal, this volume)

NA6 $=$ Chiasmolithus bidens Zone

top $=$ LO Hornibrookina teuriensis

base = FO Chiasmolithus bidens $63.2 \mathrm{Ma}$

NA5 $=$ Prinsius martinii Zone

base $=$ FO Prinsius martinii $63.8 \mathrm{Ma}$

NA4 = Chiasmolithus danicus Zone

base = FO Chiasmolithus danicus $64.8 \mathrm{Ma}$

NA3 = Cruciplacolithus tenuis Zone

base $=$ FO Cruciplacolithus tenuis $66.2 \mathrm{Ma}$

NA2 = Hornibrookina teuriensis Zone

base $=$ FO Hornibrookina $66.37 \mathrm{Ma}$

NA1 = Biantholithus sparsus Zone

base = FO Biantholithus sparsus $66.4 \mathrm{Ma}$

Planktonic foraminiferal zones (Huber, this volume)

AP3 = Acarinina esnaensis Interval Zone

top $=\mathrm{FO}$ Acarinina praepentacamerata $60.2 \mathrm{Ma}$

base = FO A. esnaensis about $62.4 \mathrm{Ma}$ (interpolated age)

AP1 = Globoconusa daubjergensis Partial Range Zone

top $=$ FO Planorotalites imitatus

base $=$ FO G. daubjergensis $66.35 \mathrm{Ma}$

$\mathrm{AP} 1 \mathrm{a}=$ Globoconusa daubjergensis Partial Range Subzone

top $=$ FO Subbotina inconstans $65.1 \mathrm{Ma}$

Radiolarian zones of Caulet (this volume)

NR1 = Antarctissa denticulata Zone

base: LO Stylatractus universus $0.425 \mathrm{Ma}$

NR2 = unnamed

base: LO Phormostichoartus pitomorphus $0.65 \mathrm{Ma}$

NR3/4 = NR 3 and NR4 Zones of Caulet (1985) (undifferentiated)

base: LCO Cycladophora pliocenica $1.6 \mathrm{Ma}$

NR5 = unnamed

base: LCO Prunopyle titan $3.2 \mathrm{Ma}$

NR6 = unnamed

base: Evolutionary transition from Helotholus praevema to Pseudocubus vema $4.2 \mathrm{Ma}$

NR7 = Desmospyris spongiosa Zone

base: FO Desmospyris spongiosa about 5.0 Ma

NR8 = Triceraspyris coronata Zone

base: LCO Stichocorys peregrina about $6.2-6.5 \mathrm{Ma}$

NR9 = Stichocorys peregrina Zone

base: FO Stichocorys peregrina about $9.3 \mathrm{Ma}$

$\mathrm{NR} 10=$ unnamed

base: $\mathrm{FCO}$ Cycladophora spongothorax $(\mathrm{FO}=11.3 \mathrm{Ma})$

$\mathrm{NR} 11$ = unnamed

base: FCO Actinomma golownini $(\mathrm{FO}=13.4 \mathrm{Ma})$

NR 12 = Calocyclas polyporos Zone

base: FCO Calcocyclas polyporos

NR 13 = Spongomelissa dilli Zone

base: FCO Spongomellissa dilli

NR 14 = Eucyrtidium punctatum Zone

base: $\mathrm{FCO}$ Euctrtidium punctatum $(\mathrm{FO}=17.3 \mathrm{Ma})$

NR $15=$ Cycladophora golli regiplieus Zone

base: $\mathrm{FCO}$ Cyclodophora golli regipileus (FO? = 19.4 Ma)

NR 16 = Cyrtocapsella tetrapera Zone

base: $\mathrm{FCO}$ Cyrtocapsella tetrapera $(\mathrm{FO} ?=22.1 \mathrm{Ma})$

Radiolarian zones of Lazarus (in press)

Lazarus (in press) utilizes the zones of Lazarus (1990) for the interval of 0-12.3 Ma (Omega Zone through Cycladophora spongothorax) and the zones of Abelmann (1990) for the interval of 12.3 to about $22 \mathrm{Ma}$ (Actinomma golownini to Cycladophora antiqua Zone) (see Gersonde et al., 1990).

New zones defined by Lazarus (in press)

Amphymenium challengerae Zone

FO $A$. challergerae to LO $A$. challengerae (= base of Tau Zone) $(6.0-5.5 \mathrm{Ma})$

Acrosphaera labrata Zone base: FO $A$. labrata $(7.0-6.0 \mathrm{Ma})$

Siphonosphaera vesuvius Zone

base: LO Cycladophora spongothorax (= top of Acrosphaera australis Zone) (8.3-7.0 Ma)

Diatom Zones of Baldauf and Barron (this volume)

NSOD 21 = Thalassiosira lentiginosa Partial-Range Zone

base: LO Actinocyclus ingens $0.62 \mathrm{Ma}$ 
Table 2 (continued).

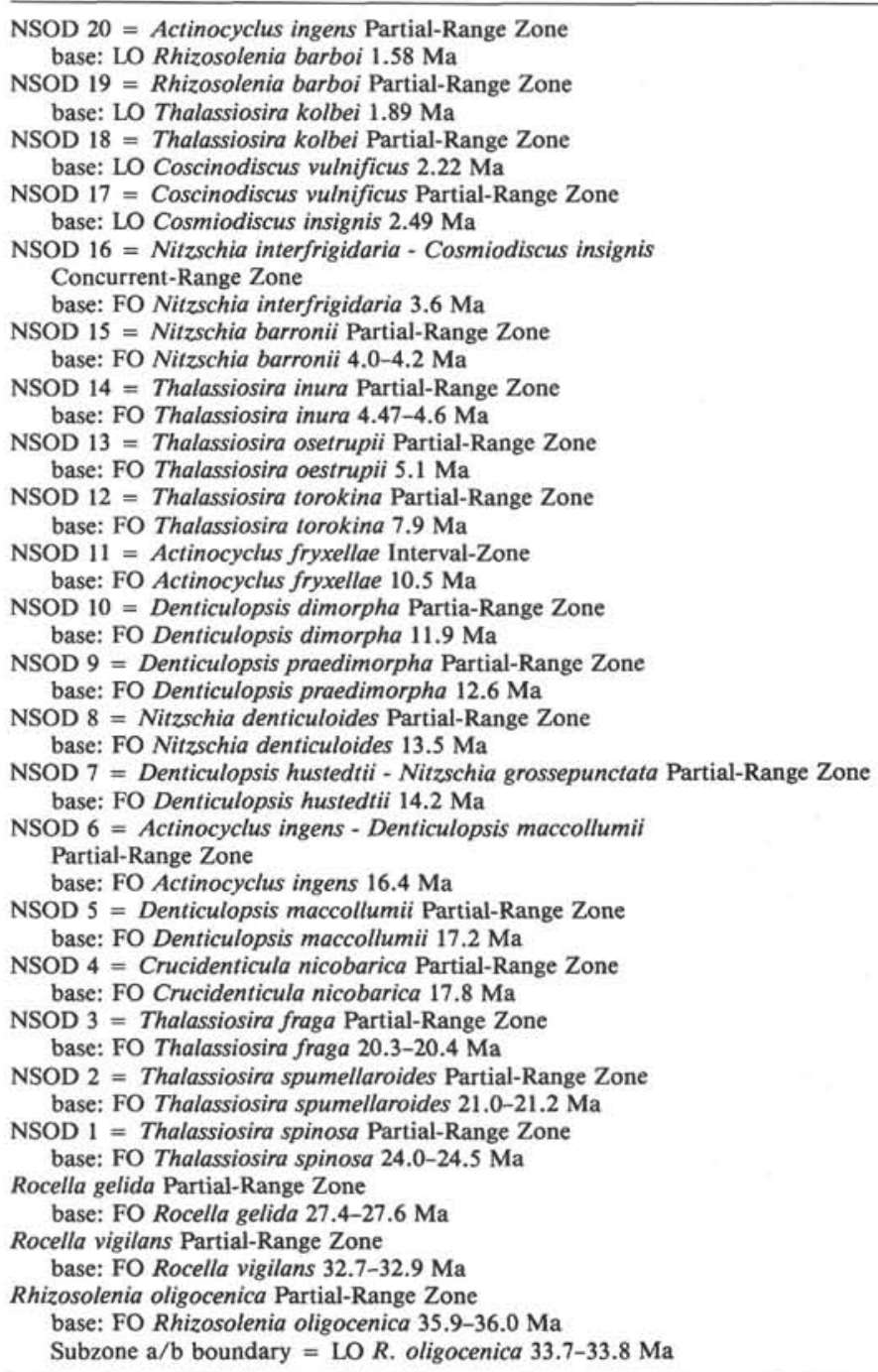

Oligocene species identified in DSDP Legs 28, 29, and 71 and collected by French researchers aboard the Marion Dufresne are endemic to the antarctic/subantarctic area. Two tropical zones, proposed by Sanfilippo and Riedel (1985), have been tentatively used for the Late Cretaceous of Site 738.

\section{Diatoms}

A Neogene Southern Ocean Diatom (NSOD) zonation has been proposed by Baldauf and Barron (this volume) based in part on zones defined by McCollum (1975), Ciesielski (1983), Barron (1985), and Gersonde and Burckle (1990) (Table 2). Three zones are also proposed for the Oligocene (Table 2). Previous studies and calibration of diatom biostratigraphy with paleomagnetic stratigraphy at Sites 744-746 have been utilized by Baldauf and Barron (this volume) to tie the Leg 119 diatom zones to the geomagnetic polarity time scale (Fig. 2).

\section{Other Microfossils}

Limited studies were also completed on Late Cretaceous dinoflagellates from Site 738 (Tocher, this volume), Quaternary silicoflagellates from Site 736 (Bukry, this volume), late Oligocene silicoflagellates from Site 744 (Bukry, this volume), and dinoflagellates from Prydz Bay Sites 739 and 742 (Truswell, this volume). Similarly, benthic foraminifers were studied from Sites
736, 738, and 744 by Schroeder-Adams (this volume), and spore and pollen assemblages from Prydz Bay Sites 739, 740, 741, and 742 were investigated by Truswell (this volume). The biostratigraphy of these groups at the various sites will be discussed briefly, but they will not be included on the downcore biochronologic figures compiled for each site because of either their sporadic nature (e.g., silicoflagellates) or their limited use for biochronology (e.g., benthic foraminifers).

\section{MAGNETOBIOCHRONOLGY OF LEG 119 SEDIMENTS}

\section{Kerguelen Plateau}

The biochronology of the various Kerguelen Plateau sections will be discussed in order of decreasing age control available from magnetobiochronologic studies; namely, the sites with the more complete, unambiguous magnetic polarity stratigraphy (Sites 745 and 746) will be treated first, followed by Site 744 , which contains a magnetic polarity record that is interrupted by numerous hiatuses.

\section{Site 745}

Site $745\left(59^{\circ} 35.71^{\prime} \mathrm{S}, 85^{\circ} 51.60^{\prime} \mathrm{E}\right)$ lies in $4093 \mathrm{~m}$ of water on a sediment ridge along the southeast slope of the Kerguelen Pla- 
teau. The ridge shows characteristics of a sediment drift on seismic lines (Barron, Larsen, et al., 1989), and drilling at Site 745 was aimed at the recovery of a deep-water Neogene section to document changes in abyssal circulation. A 215-m-thick section of uppermost Miocene through Quaternary silty diatom ooze and diatom clay was cored in two holes at the site (Fig. 3). Site 745 was below the carbonate compensation depth (CCD) during this whole interval, so calcareous microfossils are extremely rare in the sediments recovered, whereas high-diversity and well-preserved diatom and radiolarian occur in moderate to high abundance throughout the sequence.

Magnetic polarity stratigraphy identified a complete polarity sequence from the Brunhes Normal-Magnetic Polarity Chron to Subchron $3 \mathrm{AN}-2$ of Chron $3 \mathrm{~A}$ (Sakai and Keating, this volume). This polarity sequence is well-constrained by diatom and radiolarian datum levels (Table 3), and its interpretation is, for the most part, straightforward. Sakai and Keating (this volume), however, identified five normal polarity intervals within the Gilbert Reversed-Magnetic Polarity Chron between 132.8 and 180 mbsf instead of the expected four events. Published microfossil datum levels (Table 3 ) suggest that the upper two of these normal intervals coincide with the Cochiti $(\mathrm{C} 3 \mathrm{~N}-1)$ and Nunivak $(\mathrm{C} 3 \mathrm{~N}-2)$ events, the third and fourth events are equivalent to the Sidufjall (C3N-3), and the lowermost event between about 178 and 181 mbsf should be the Thvera $(\mathrm{C} 3 \mathrm{~N}-4)$ event. Use of the Berggren et al. $(1985 \mathrm{~b}, \mathrm{c})$ magnetic polarity time scale, however, results in irregularities in the age vs. depth plot for Site 745 (Fig. 4); namely, the lowermost reversed event of the Gilbert Reversed-Polarity Chron appears to be abnormally compressed.

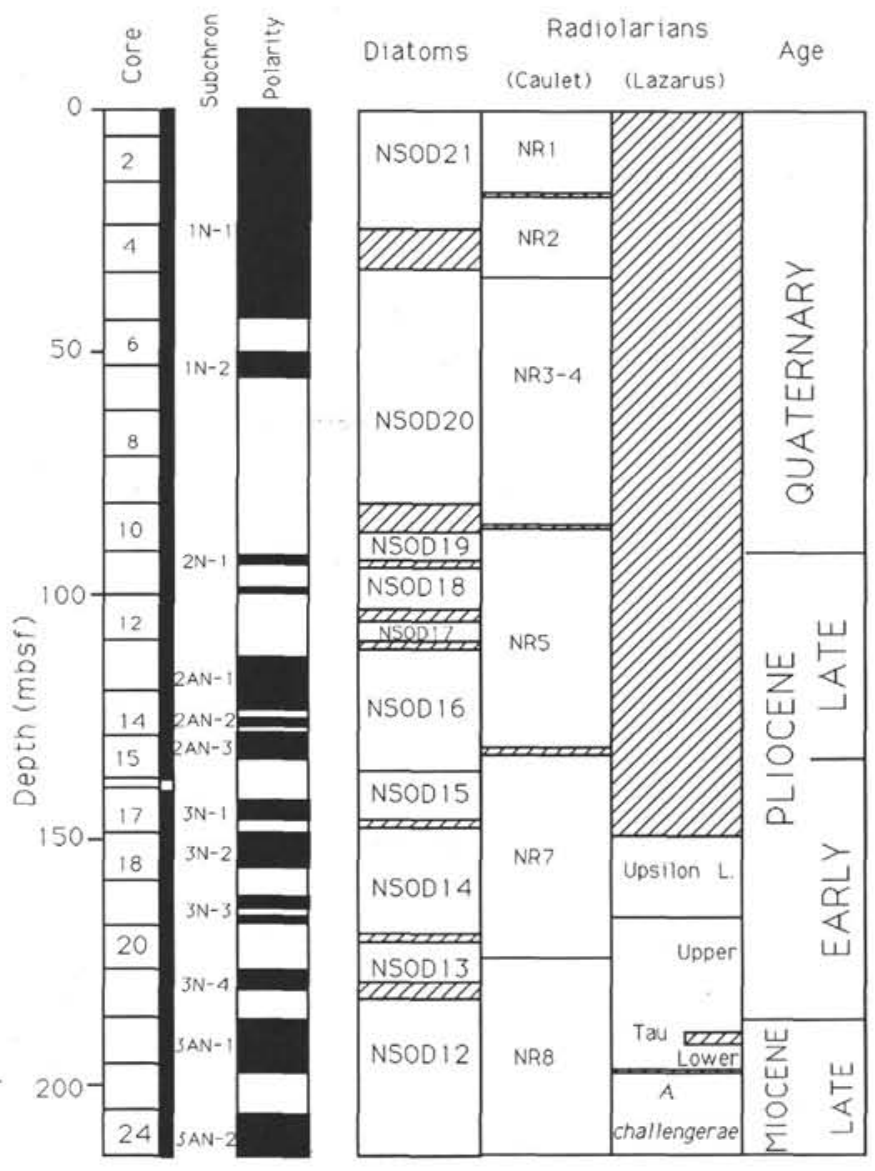

Figure 3. Magnetostratigraphy and biostratigraphy of Hole 745B. Diagonal lines shown for intervals of uncertainty or lacking study.
This compression may be an artifact of the Berggren et al. (1985 b, c) time scale. Sakai and Keating (this volume), point out that Mankinen and Cox (1988) assign a 4.85-5.00 Ma age to the Thvera Normal-Polarity Subchron, substantially older than the 4.32-4.47 Ma-age that they assign to the Sidufjall NormalPolarity Subchron (of the Gilbert). Berggren et al. (1985b, c), on the other hand, place these two normal polarity events closer in time (4.57-4.77 $\mathrm{Ma}$ and $4.40-4.47 \mathrm{Ma}$, respectively). The sequence of normal events in Hole 745B more closely resembles the equally-spaced chronological sequence of Gilbert events of the Mankinen and Cox (1988) time scale than the sequence in the Berggren et al. (1985c) scale.

Figure 4 shows an age vs. depth plot for the sediment section recovered in Hole $745 \mathrm{~B}$ constructed from the magnetostratigraphic interpretation shown in Table 3. Post-compaction sedimentation rates average about $55 \mathrm{~m} / \mathrm{m}$.y. for the Quaternary of Site 745 (Fig. 4). The relatively short section for the Olduvai Normal-Polarity Subchron (of the Matuyama Reversed-Polarity Chron) (1.66-1.88 Ma) (about 91.5-93.5 mbsf) suggests the possibility of a short hiatus or interval of reduced sedimentation rate, but microfossil studies in this interval are not detailed enough to support this conclusion. Between 1.9 and $4.10 \mathrm{Ma}$ (94 and 149 mbsf), post-compaction sedimentation rates average $26 \mathrm{~m} / \mathrm{m}$.y. They appear to increase briefly to $53 \mathrm{~m} / \mathrm{m}$.y. between 4.10 and $4.77 \mathrm{Ma}$ (149 and $181 \mathrm{mbsf}$ ) and then fall to about 10 $\mathrm{m} / \mathrm{m}$.y. between 4.77 and $5.35 \mathrm{Ma}$ (181 and $186.5 \mathrm{mbsf}$ ); however, as discussed in the previous section, these changes may be artifacts of the Berggren et al $(1985 \mathrm{~b}, \mathrm{c})$ time scale. Disregarding the age assignments of the Sidufjall and Thvera events, post-compaction sedimentation rates average about $30 \mathrm{~m} / \mathrm{m} . \mathrm{y}$. for the lower part of the Gilbert. Below, rates increase to about $40 \mathrm{~m} / \mathrm{m} . \mathrm{y}$. between $5.35 \mathrm{Ma}$ and $5.8 \mathrm{Ma}$ (186.5 and $215 \mathrm{mbsf}$ ), the base of Hole 745B.

Diatom and radiolarian events generally lie on the age vs. depth plot for Site 745 using ages from the literature (Fig. 4), with the exception of diatom events D4 (the first occurrence of Coscinodiscus elliptopora), D6 (the first occurrence of Nitzschia kerguelensis), D12 (the first occurrence of Rouxia heteropolara), and D13 (the first occurrence of Nitzschia barronii). All these diatoms are endemic to Antarctic waters, and it is possible that they evolved earlier closer to the Antarctic coast (compare Gersonde and Burckle, 1990).

\section{Site 746}

Site $746\left(59^{\circ} 32.82^{\prime} \mathrm{S}, 85^{\circ} 51.78^{\prime} \mathrm{E}\right.$; water depth $\left.4059.5 \mathrm{~m}\right)$ was offset about $5 \mathrm{~km}$ north of Site 745 and located over a seismically equivalent section in order that the drilling program began at Site 745 could be continued after a large iceberg had disrupted drilling operations at that site. Continuous coring at Site 746 began at $164.8 \mathrm{mbsf}$ and continued until $280.8 \mathrm{mbsf}$. The upper Miocene sequence of diatomaceous clay and silty clay recovered closely resembles the section recovered at Site 745 (Barron, Larsen, et al., 1989).

Diatoms are abundant and relatively common throughout the sequence cored at Site 746, whereas radiolarians decline in abundance and preservation below Core 119-746A-10H (227 mbsf). Diatom and radiolarian biostratigraphy for the continuously-cored 164.8-280.8 mbsf interval of Hole 746A along with the downhole magnetic polarity log of Sakai and Keating (this volume) are presented in Figure 5. Diatom datum levels (Table 4) provide constraints for the interpretation of the magnetic polarity stratigraphy, and the assignment of magnetic polarity subchrons is relatively straightforward.

A sequence from Subchron $3 \mathrm{AN}-2$ to Subchron $5 \mathrm{~N}-1$ has been interpreted for the continuously-cored section of Hole 746A (Sakai and Keating, this volume; Fig. 5). Thus, continuous coring in Hole 746A begins in Subchron 3AN-2 (164.8 to 
Table 3. Age model for Hole 745B showing stratigraphic interval of biostratigraphic datum levels and paleomagnetic subchron boundaries.

\begin{tabular}{|c|c|c|c|c|}
\hline & Datum & $\begin{array}{l}\text { Depth } \\
\text { (mbsf) }\end{array}$ & $\begin{array}{l}\text { Published } \\
\text { age (Ma) }\end{array}$ & Source ${ }^{a}$ \\
\hline R1 & LO Stylatractus universus & $16.5-18$ & 0.43 & 6 \\
\hline D1 & LO Actinocyclus ingens & $24.0-33.5$ & 0.62 & 1 \\
\hline R2 & LO Antarctissa cylindrica & $34.0-35.5$ & 0.55 & 6 \\
\hline PM & C1N-1 base & $42.36-42.6$ & 0.73 & \\
\hline D2 & LO Coscinodiscus elliptopora & $43.0-52.5$ & 0.65 & 1 \\
\hline PM & $\mathrm{C} 1 \mathrm{~N}-2$ top & $50.08-50.43$ & 0.91 & \\
\hline PM & $\mathrm{C} 1 \mathrm{~N}-2$ base & $54.31-54.97$ & 0.98 & \\
\hline R3 & LCO Cycladophora pliocenica & $84.5-86$ & 1.60 & 6 \\
\hline D3 & LO Rhizosolenia barboi & $81.0-90.5$ & 1.58 & 1 \\
\hline D4 & FO Coscinodiscus elliptopora & $81.0-90.5$ & 2.2 & 1 \\
\hline PM & $\mathrm{C} 2 \mathrm{~N}-1$ top & $91.3-91.8$ & 1.66 & \\
\hline D5 & LO Thalassiosira kolbei & $90.5-94.1$ & 1.89 & 1 \\
\hline PM & $\mathrm{C} 2 \mathrm{~N}-1$ base & $93.3-93.8$ & 1.88 & \\
\hline D6 & FO Nitzschia kerguelensis & $94.1-98.6$ & 2.7 & 2 \\
\hline D7 & LO Coscinodiscus vulnificus & $102.1-105.1$ & 2.22 & 3 \\
\hline R4 & LO Pseudocubus vema & $109.5-110$ & 2.4 & 6 \\
\hline D8 & LO Cosmiodiscus insignis & $108.1-111.6$ & 2.49 & 1 \\
\hline PM & C2AN-1 top & $112.3-112.8$ & 2.47 & \\
\hline R5 & FO Cycladophora davisiana & $114.5-116$ & 2.7 & 6 \\
\hline D9 & LO Nitzschia praeinterfrigidaria & $114.1-125.5$ & 2.8 & 1 \\
\hline D10 & FO Coscinodiscus vulnificus & $114.1-125.6$ & 3.1 & 1 \\
\hline PM & $\mathrm{C} 2 \mathrm{AN}-1$ base & $123.3-123.8$ & 2.92 & \\
\hline PM & C2AN-2 top & $125.3-125.8$ & 2.99 & \\
\hline PM & $\mathrm{C} 2 \mathrm{AN}-2$ base & $126.3-126.8$ & 3.08 & \\
\hline PM & $\mathrm{C} 2 \mathrm{AN}-3$ top & $128.3-128.8$ & 3.18 & \\
\hline R6 & LO Prunopyle titan & $130.5-132$ & 3.2 & 6 \\
\hline PM & $\mathrm{C} 2 \mathrm{AN}-3$ base & $132.8-133.3$ & 3.40 & \\
\hline D11 & FO Nitzschia interfrigidaria & $135.1-136.5$ & 3.6 & 4 \\
\hline D12 & FO Rouxia heteropolara & $139.0-141.1$ & 4.3 & 4 \\
\hline PM & $\mathrm{C} 3 \mathrm{~N}-1$ top & $142.41-143.05$ & 3.88 & \\
\hline D13 & FO Nitzschia barronii & $144.1-145.6$ & 4.2 & 4 \\
\hline PM & $\mathrm{C} 3 \mathrm{~N}-1$ base & $145.8-146.75$ & 3.97 & \\
\hline PM & $\mathrm{C} 3 \mathrm{~N}-2$ top & $148.93-149.93$ & 4.10 & \\
\hline R7 & FO Pseudocubus vema & $153.5-156.5$ & 4.20 & 6 \\
\hline PM & $\mathrm{C} 3 \mathrm{~N}-2$ base & $155.7-156.15$ & 4.24 & \\
\hline PM & $\mathrm{C} 3 \mathrm{~N}-3$ top & $160.53-161.11$ & 4.40 & \\
\hline PM & $\mathrm{C} 3 \mathrm{~N}-3$ base & $167.56-168.24$ & 4.47 & \\
\hline D14 & FO Thalassiosira inura & $168.1-172.6$ & 4.47 & 4 \\
\hline PM & $\mathrm{C} 3 \mathrm{~N}-4$ top & $177.05-178.84$ & 4.57 & \\
\hline D15 & FO Thalassiosira oestrupii & $179.1-183.6$ & 5.1 & 5 \\
\hline PM & C $3 \mathrm{~N}-4$ base & $180.34-181.15$ & 4.77 & \\
\hline PM & C3AN-1 top & $186.19-186.55$ & 5.35 & \\
\hline PM & C3AN-1 base & $196.35-197.1$ & 5.53 & \\
\hline PM & $\mathrm{C} 3 \mathrm{AN}-2$ top & $205.41-205.9$ & 5.68 & \\
\hline D16 & FO Thalassiosira miocenica & $204.1-207.6$ & 5.8 & 5 \\
\hline PM & C3AN-2 base & $>214.85$ & 5.89 & \\
\hline
\end{tabular}

a 1 = Ciesielski, 1983; 2 = McCollum, 1975; 3 = Weaver and Gombos, 1981; 4 = Gersonde and Burckle, 1990; 5 = Barron, in press; 6 = Lazarus, 1990.

about $169 \mathrm{mbsf}$ ) within an age-equivalent interval to that where coring was terminated in Hole 745B; namely, Subchron 3AN-2, which was identified between 205.5 and 214.85 mbsf in Hole 745B.

An age vs. depth plot for Hole 746A is constructed from the magnetostratigraphic interpretations (Table 4) in Figure 6. Postcompaction sedimentation rates average $27 \mathrm{~m} / \mathrm{m}$.y. between 168 and 205 mbsf (5.89 and 7.28 Ma). Between 205 and $229 \mathrm{mbsf}$ $(7.28$ and $7.9 \mathrm{Ma}$ ) rates rise to about $39 \mathrm{~m} / \mathrm{m}$.y. before falling to about $13 \mathrm{~m} / \mathrm{m}$.y between 229 and $242 \mathrm{mbsf}$ (7.9-8.9 Ma). Below $242 \mathrm{mbsf}$ post-compaction sedimentation rates are inferred to be at least $40 \mathrm{~m} / \mathrm{m}$.y. based on the absence of common Denticulopsis dimorpha (a diatom) at $272.4 \mathrm{mbsf}$, which implies an age younger than 9.9 Ma (Gersonde and Burckle, 1990).

Diatom events D1 to D11, between 6 and $8 \mathrm{Ma}$, are consistently offset to the right (younger) of the age vs. depth plot generated from the magnetostratigraphy (Fig. 6). Many of these events represent the first occurrences of low-latitude or temperate diatom taxa, so it is not surprising that their first occurrences at Site 746 at $59^{\circ} \mathrm{S}$ are somewhat delayed. An exception is event D13, the last occurrence of Asteromphalus kennettii, which appears to be older at Site 746 than at Leg 113 Site 689 on the Maud Rise in the Weddell Sea (Gersonde and Burckle, 1990).

\section{Site 744}

Site $744\left(61^{\circ} 34.6^{\prime} \mathrm{S}, 80^{\circ} 35.46^{\prime} \mathrm{E}\right)$ was drilled on the southern Kerguelen Plateau in $2307 \mathrm{~m}$ of water in order to recover a more complete Oligocene and Neogene section than the one recovered at Site 738, about $250 \mathrm{~km}$ to the southeast (Fig. 1). The 176.1m-thick section cored consists of a 24-m-thick uppermost Miocene to Quaternary diatomaceous ooze with a variable content of carbonate, overlying a 152-m-thick section of upper Eocene to uppermost Miocene nannofossil ooze (Barron, Larsen, et al., this volume). The nannofossil ooze contains a minor, but wellpreserved, biosiliceous component in the post-Eocene part of the section, so that most of the Oligocene and Miocene is zonable by both calcareous (planktonic foraminifers and nannofossils) and siliceous (radiolarians and diatoms) microfossils.

Figures 7 and 8 show the downcore magnetic polarity logs after Keating (this volume), along with diatom (Baldauf and Barron, this volume), radiolarian (Caulet, this volume; Laza- 


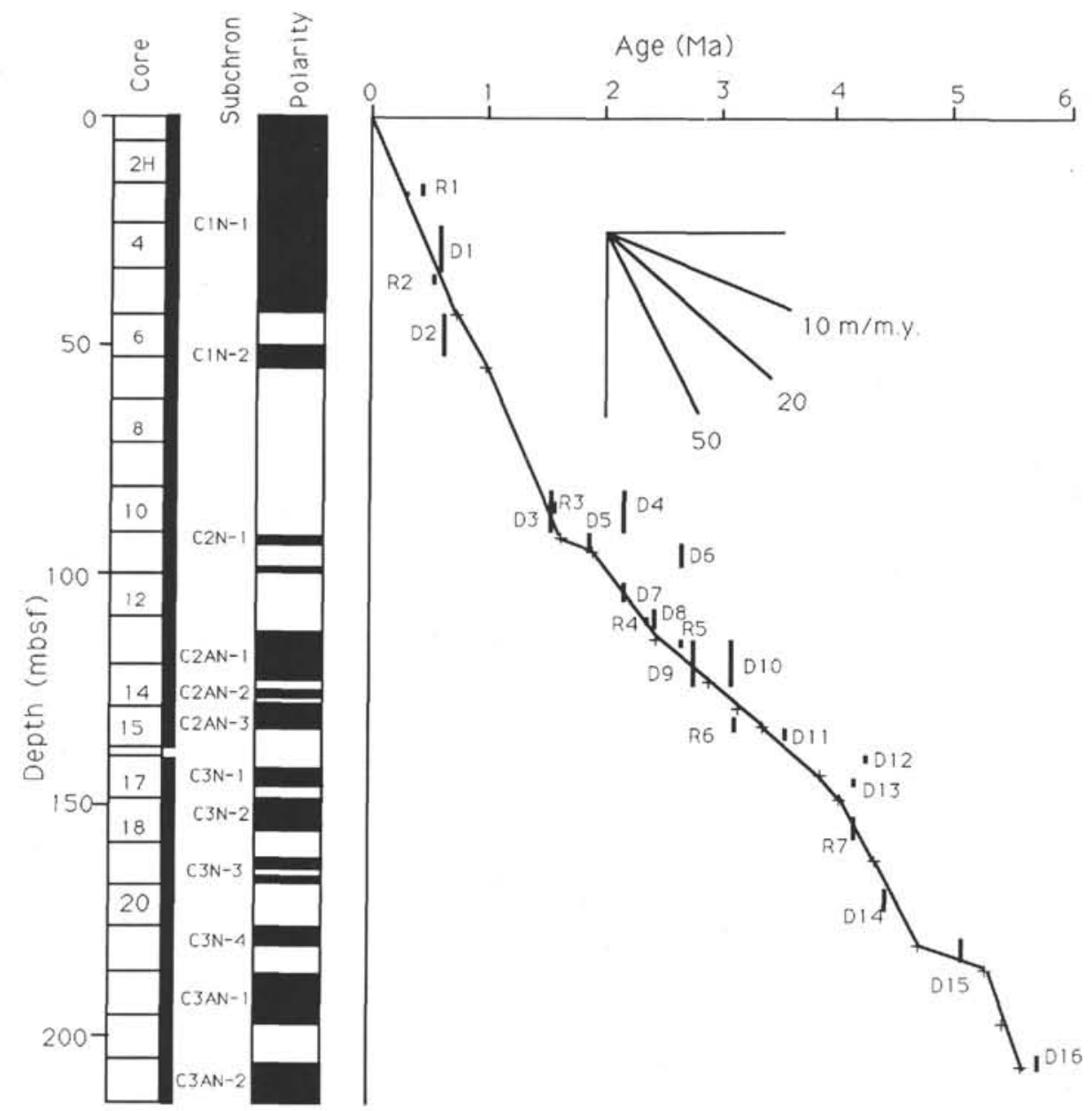

Figure 4. Age vs. depth plot for Hole 745B utilizing the magnetostratigraphic $(+)$ and biostratigraphic events of Table 2 .

rus, in press), calcareous nannofossil (Wei and Thierstein, this volume), and planktonic foraminiferal (Huber, this volume) zones for the Neogene and Paleogene, respectively, of Holes $744 \mathrm{~A}$ and 744B. The data for the interval 0-78.5 mbsf are given for Hole 744B rather than for Hole 744A, because recovery is virtually $100 \%$ for Hole $744 \mathrm{~B}$, but considerably less for Hole 744A (Fig. 7).

The assignment of magnetic polarity chrons and subchrons at Site 744 (Figs. 7 and 8) is constrained by microfossil datum levels, oxygen isotope events (Woodruff and Chambers, this volume), and strontium isotope studies (Barrera et al., this volume; W. Wei, S. W. Wise, K. Miller, and M. D. Feigenson, pers. comm., 1989), as shown in Table 5.

This age model (Table 5) is used to construct age vs. depth plots for the Neogene (Fig. 9) and Paleogene (Fig. 10) drawn on the interpreted boundaries of magnetic polarity events. A seemingly complete sequence from the Brunhes Normal-Polarity Chron (Chron 1) through the Gauss Normal-Polarity (Chron $2 \mathrm{~A})$ is present between the seafloor and about $20 \mathrm{mbsf}$, although sample spacing for paleomagnetic studies is not detailed enough to resolve the Jaramillo Normal-Polarity Subchron (of the Matuyama) or the Kaena and Mammoth Reversed-Polarity Subchrons (of the Gauss) (Keating, this volume). Post-compaction sedimentation rates average 5 to $6 \mathrm{~m} / \mathrm{m}$.y. in this interval.

Radiolarian biostratigraphy reveals that Zone NR8 is missing between Samples 119-744B-3H-CC (21.5 mbsf) and -744A-3HCC (23.2 mbsf) (Caulet, this volume). Coincidence of the first occurrences of the diatom Nitzschia barronii, Nitzschia praeinterfrigidaria, Thalassiosira inura, and Thalassiosira oestrupii (events D7 to D10 of Table 5) in this interval and interpretation of magnetostratigraphy (Table 5 and Figs. 7 and 9) imply that the period from about 5.6 to $4.2 \mathrm{Ma}$ is absent at a disconformity at about 22 mbsf. This hiatus incorporates widespread deep-sea hiatus NH7 (5.2-4.7 Ma) of Keller and Barron (1987) as well as younger parts of the early Pliocene.

Below this disconformity is a 2-m-thick uppermost Miocene section that appears to correlate with magnetic polarity Subchron C3AN-2 (Figs. 7 and 9) based on biostratigraphy (Table 5). This short section overlies a second disconformity at about 24 mbsf, which spans the interval between 8.9 and $6.0 \mathrm{Ma}$ according to diatom and radiolarian stratigraphy (Baldauf and Barron, this volume; Lazarus, in press). This second disconformity coincides with the erosional contact between lithologic Unit I, a diatom ooze with minor carbonate, and Unit II, a nannofossil ooze (Barron, Larsen, et al., 1989; Dorn, this volume). It also marks the boundary between a latest Miocene to Quaternary benthic foraminiferal assemblage dominated by Epistominella and a late early Miocene to late middle Miocene assemblage dominated by Bolivina thalmanni (Schroeder-Adams, this volume). The hiatus is equivalent to widespread deep-sea hiatuses NH5 (8.6-8.0 Ma) and NH6 (7.0-6.0 Ma) of Keller and Barron (1987).

Between about 24 and 53 mbsf post-compaction sedimentation rates increase to about $12 \mathrm{~m} / \mathrm{m}$.y. within an interval as- 


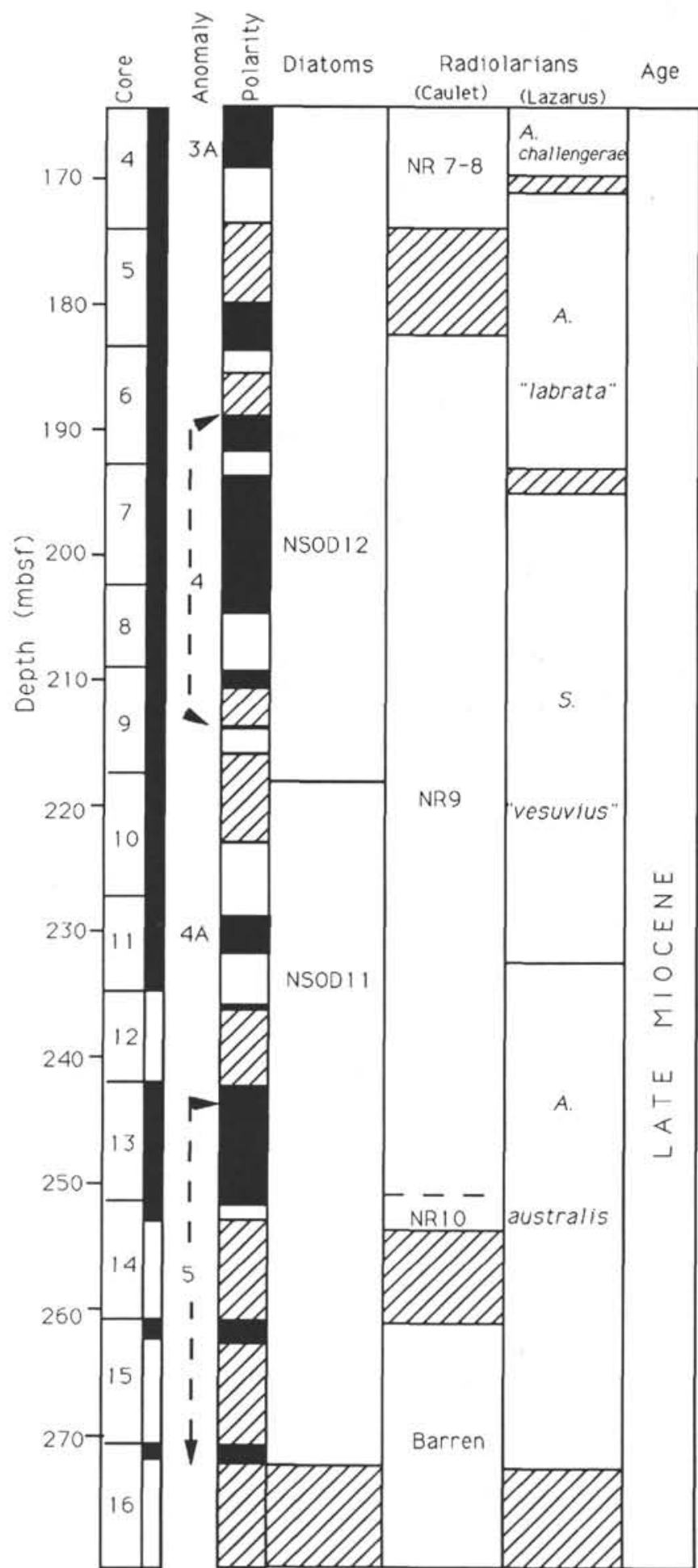

Figure 5. Magnetostratigraphy and biostratigraphy of Hole 746A. Diagonal lines shown for intervals of uncertainty or lacking study.

signed to 8.9-11.2 Ma (Chron 5). A third disconformity occurs at a lithologic color change at 53 mbsf (Barron, Larsen, et al., 1989) where the age model of Table 5 and Figure 9 implies that magnetic polarity Subchrons $\mathrm{C} 5 \mathrm{AN}-1$ and $\mathrm{C} 5 \mathrm{AN}-2$ are missing at a hiatus spanning the interval from about 11.2 to $12.2 \mathrm{Ma}$. Volume magnetic susceptibility increases nearly 10 -fold down section at 53 mbsf (Dorn, this volume) which suggests a change in sediment character, and oxygen, and carbon isotope studies (Woodruff and Chamber, this volume) reveal that section is missing.

A probable fourth hiatus lies a short distance below at about 54.5-55.2 mbsf, based on diatom and radiolarian stratigraphy, oxygen and carbon isotope studies (Woodruff and Chamber, this volume), and interpretation of the age model of Table 5 and Figure 9. This hiatus appears to span the interval from about 12.5 to $13.4 \mathrm{Ma}$, including at least Subchrons C5AN-5 and C5AN-6, and it approximates the boundary between a late middle Miocene to early late Miocene benthic foraminiferal assemblage dominated by Bolivina thalmanni and an early Oligocene to middle Miocene assemblage characterized by Nuttallides umbonifera (Schroeder-Adams, this volume).

Between about 55 and 66.9 mbsf (12.2 and about $17 \mathrm{Ma})$ sedimentation rates (post-compaction) are about $3-4 \mathrm{~m} / \mathrm{m} . \mathrm{y}$. (Fig. 9). Below, post-compaction sedimentation rates rise to about 7-8 m/m.y between 66.9 and $96 \mathrm{mbsf}$ (17-21 Ma) (Fig. 9). A disconformity at about 97 mbsf between Samples 119$744 \mathrm{~A}-11 \mathrm{H}-5,92-93 \mathrm{~cm}$, and 119-744A-11H-6, 63-65 cm, coincides with most of the lowermost Miocene (about 21.3-24 Ma) according to strontium isotope studies (Barrera et al., this volume), diatom biostratigraphy (Baldauf and Barron, this volume), and interpretations of magnetostratigraphy (Table 5 and Fig. 7). Whether this hiatus is related to the opening of the Drake Passage, which occurred in the earliest Miocene according to Barker and Burrell (1982), is unclear.

An approximately 2-m-thick uppermost Oligocene section corresponding to the interval from about 24.0 to $24.5 \mathrm{Ma}$ is inferred between 97 and 99 mbsf based on strontium isotope studies (Barrera et al., this volume; W. Wei, S. W. Wise Jr., K. G. Miller, and M. D. Feigenson, pers. comm., 1989) and the overlap in ranges of the nannofossil Reticulofenestra bisecta with the diatom Thalassiosira spinosa (Table 5 and Fig. 9). This section appears to be underlain by a disconformity that spans the interval from about 24.5 to $26.3 \mathrm{Ma}$ based on the interpretation of the magnetic polarity stratigraphy shown in Figure 10. This hiatus lies at or near the core break between Cores 119-744A$11 \mathrm{H}$ and $119-744 \mathrm{~A}-12 \mathrm{H}$, and its existence is hard to argue based on biostratigraphy alone.

Post-compaction sedimentation rates average $8-9 \mathrm{~m} / \mathrm{m}$.y. in the upper Oligocene of Site 744 between about 99 to about 118 mbsf (26.3-28.4 Ma). Silicoflagellates from this interval are assignable to the Distephanus speculum haliomma Subzone of the Naviculopsis biapiculata Zone by Bukry (this volume).

A fairly major hiatus is present in the lowermost part of Core $119-744 \mathrm{~A}-13 \mathrm{H}$ at about $118 \mathrm{mbsf}$ based on strontium isotope studies (Barrera et al., this volume) and oxygen isotope studies (Barrera and Huber, this volume). Caulet (this volume) reports the last occurrences of seven radiolarian taxa at this horizon, but diatoms (Baldauf and Barron, this volume) and calcareous nannofossils (Wei and Thierstein, this volume) show little change. Huber (this volume) records the last abundant occurrence of the planktonic foraminifer Chiloguembelina cubensis between 117.15 and 118.20 mbsf, and one isolated sparse occur-

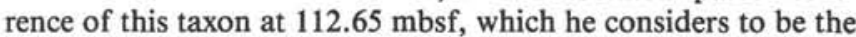
last occurrence (event F5, 30.0 Ma). If this isolated occurrence represents reworking, event F5 may better be placed at the last abundant occurrence of the taxon between 117.15 and 118.20 mbsf, the probable horizon for a middle Oligocene hiatus. Thus, the middle Oligocene interval between 32 and $28.5 \mathrm{Ma}$ is either very compressed or missing in part in this $118-116$ mbsf interval. Keller et al. (1987) identified widespread Paleogene deep-sea hiatuses PHaa (28.1-29.2 Ma) and PHb (30.3-31.4 $\mathrm{Ma})$ in this same time interval.

Below this middle Oligocene hiatus, post-compaction sedimentation rates average between 7 and $8 \mathrm{~m} / \mathrm{m}$.y. in the upper 
Table 4. Age model for Hole 746B showing stratigraphic interval of biostratigraphic datum levels and paleomagnetic subchron boundaries.

\begin{tabular}{|c|c|c|c|c|}
\hline & Datum & $\begin{array}{l}\text { Depth } \\
\text { (mbsf) }\end{array}$ & $\begin{array}{l}\text { Published } \\
\text { age (Ma) }\end{array}$ & Source ${ }^{a}$ \\
\hline D1 & FO Thalassiosira convexa aspinosa & $165.4-166.9$ & $* 6.11$ & \\
\hline D2 & FO Thalassiosira miocenica & $65.4-166.9$ & 5.8 & 1 \\
\hline PM & $\mathrm{C} 3 \mathrm{AN}-2$ base & $168.11-169.61$ & 5.89 & \\
\hline D3 & FO Thalassiosira praeconvexa & $169.9-171.4$ & $* 6.31$ & \\
\hline D4 & FO Thalassiosira cf. jacksonii & $171.4-172.9$ & 6.41 & \\
\hline D5 & FO Nitzschia miocenica & $172.9-174.3$ & *6.75 & 1 \\
\hline D6 & LO Thalassiosira burckliana & $176.4-177.9$ & $* 7.01$ & \\
\hline PM & C3AN-3 top & $179.85-180.88$ & 6.37 & \\
\hline PM & $\mathrm{C} 3 \mathrm{AN}-3$ base & $183.18-183.43$ & 6.50 & \\
\hline D7 & LO Actinocyclus ingens var. ovalis & $183.8-184.4$ & 7.22 & \\
\hline PM & $\mathrm{C} 4 \mathrm{~N}-1$ top & $188.58-189.66$ & 6.70 & \\
\hline PM & $\mathrm{C} 4 \mathrm{~N}-2$ base & $191.93-192.65$ & 6.78 & \\
\hline PM & $\mathrm{C} 4 \mathrm{~N}-2$ top & $193.25-193.69$ & 6.85 & \\
\hline D8 & FO Nitzschia marina-reinholdii & 203.4-204.9 & $* 7.41$ & \\
\hline PM & $\mathrm{C} 4 \mathrm{~N}-2$ base & $204.36-205.58$ & 7.28 & \\
\hline D9 & FO Actinocyclus ingens var. ovalis & 204.9-206.4 & 7.92 & \\
\hline D10 & FO Nitzschia marina-cylindrica & $206.4-208.0$ & $* 7.55$ & 1 \\
\hline PM & $\mathrm{C} 4 \mathrm{~N}-3$ top & ca. 209.3 & 7.35 & \\
\hline PM & $\mathrm{C} 4 \mathrm{~N}-3$ base & ca. 213.8 & 7.41 & \\
\hline D11 & FO Cosmiodiscus intersectus & $219.9-221.4$ & 7.9 & 2 \\
\hline PM & C4AN-1 top & $228.6-229.1$ & 7.90 & \\
\hline PM & C4AN-1 base & $231.1-231.6$ & 8.21 & \\
\hline D12 & FO Thalassiosira burckliana & $234.8-235.4$ & $* 8.2$ & 1 \\
\hline PM & C4AN-2 top & $236.1-236.5$ & 8.41 & \\
\hline D13 & LO Asteromphalus kennettii & $234.8-242.2$ & 7.1 & 2 \\
\hline PM & $\mathrm{C} 5 \mathrm{~N}-1$ top & $<242.4$ & 8.92 & \\
\hline D14 & FO Asteromphalus kennettii & $252.4-262.0$ & 9.6 & 2 \\
\hline D15 & LCO Denticulopsis dimorpha & $>272.4$ & 9.9 & 2 \\
\hline
\end{tabular}

${ }^{\text {a }} 1$ = Barron, in press; 2 = Gersonde and Burckle, 1990.

* = tropical datum.

Eocene and lower Oligocene interval at the bottom of Hole 744A (about 32-39.4 Ma; 118-176 mbsf) (Fig. 10). The Eocene/ Oligocene boundary at about 153 mbsf is marked a gradual transition from a late Eocene benthic foraminiferal assemblage characterized by Bulimina semicostata to an early Oligocene to middle Miocene assemblage characterized by $N$. umbonifera (Schroeder-Adams, this volume).

\section{Site 738}

A 486-m-thick lower Turonian through Quaternary sediment section overlying $38 \mathrm{~m}$ of volcaniclastic rocks and altered basalt was cored at Site $738\left(62^{\circ} 42.54^{\prime} \mathrm{S}, 82^{\circ} 47.25^{\prime} \mathrm{E}\right.$; water depth $2252.5 \mathrm{~m}$ ), about $250 \mathrm{~km}$ southeast of Site 744 on the southern tip of the Kerguelen Plateau (Fig. 1). The Neogene consists of 16.8-m-thick uppermost Miocene to Quaternary diatom ooze which overlies $0.9 \mathrm{~m}$ of upper Miocene nannofossil ooze containing a minor biosiliceous component. The bulk of the section is dominantly carbonate (nannofossil ooze, chalk, and limestone) and ranges in age from early Turonian to early Oligocene (Figs. 11 and 12). In general, calcareous microfossils (foraminifers and calcareous nannofossils) are abundant and well preserved throughout the Site 738 sediment section, whereas diatoms and radiolarians are mostly restricted to the thin lower Oligocene to Quaternary section.

Magnetostratigraphic interpretations are presently limited to the Upper Cretaceous to lower Paleocene of Hole 738C (Sakai and Keating, this volume), so that the age model for interpretation of the magnetobiochronology of Site 738 (Table 6) is based mostly on microfossil datum levels. These datum levels and the limited magnetostratigraphic data are utilized in Figures 13 and 14 to construct age vs. depth plots for the middle Eocene to Oligocene and the Maestrichtian to lower Eocene intervals, respectively. An age vs. depth plot is not constructed for the thin Neogene section, because biostratigraphic studies in this interval are not sufficiently detailed. The plot was not extended below the
Maestrichtian, because recovery in this interval is relatively poor.

Radiolarian stratigraphy suggests that much of the upper Pliocene to lower Pleistocene is missing at a hiatus between Samples 119-738B-1H-CC and 119-738B-2H-CC (4.05-13.5 mbsf) (Caulet, this volume); other biostratigraphic studies, however, are not detailed enough to confirm the presence of such a hiatus (Barron, Larsen, et al., 1989; J. Baldauf and J. A. Barron, unpubl. data).

Diatom stratigraphy argues for the presence of a hiatus spanning the interval from $6.0 \mathrm{Ma}$ to at least $8.4 \mathrm{Ma}$ at $16.75 \mathrm{mbsf}$ (in Section 119-738B-3H-3), at the sharp contact between lithologic unit I (a diatom ooze) and unit II (a nannofossil ooze with a minor biosiliceous component) (Barron, Larsen, et al., 1989). A seemingly time-equivalent hiatus covering the interval from 6.0 to $8.9 \mathrm{Ma}$ was encountered at Site 744 .

A major disconformity separates upper Miocene sediments in Sample 119-738B-3H-3, 130-132 cm (17.8 mbsf) (radiolarian Zone NR10), from lowermost Oligocene sediments in Sample 119-738B-3H-4, 53-55 cm (18.53 mbsf) (Caulet, this volume). Diatoms in Sample 119-737B-3H-3, 110-112 cm (17.6 mbsf), are assigned to Zone NSOD 10 and are younger than $9.9 \mathrm{Ma}$ (absence of common Denticulopsis dimorpha). Calcareous nannofossils in Sample 119-738B-3H-4, 66-68 cm (18.66 mbsf), belong to the Blackites spinosus Zone (about 35-36 Ma), so the hiatus spans at least the interval from 35 to $9.9 \mathrm{Ma}$.

Post-compaction sedimentation rates average about 5-6 m/ m.y. for the upper Eocene to lowermost Oligocene interval cored between 18.6 and 40 mbsf (35-38.8 Ma). Below, rates increase to about $19 \mathrm{~m} / \mathrm{m}$.y. for the lower part of the upper Eocene and most of the middle Eocene, between 40 and 205 mbsf (38.8-49.8 Ma) (Fig. 13). A possible short hiatus (41.0-41.4 $\mathrm{Ma}$ ) is indicated at about $71 \mathrm{mbsf}$ where calcareous nannofossil Subzone CP14b in missing (Fig.11) (Wei and Thierstein, this volume). Four benthic foraminifers (Alabamina dissonata, Ano- 
BIOCHRONOLOGIC AND MAGNETOCHRONOLOGIC SYNTHESIS OF LEG 119 SEDIMENTS

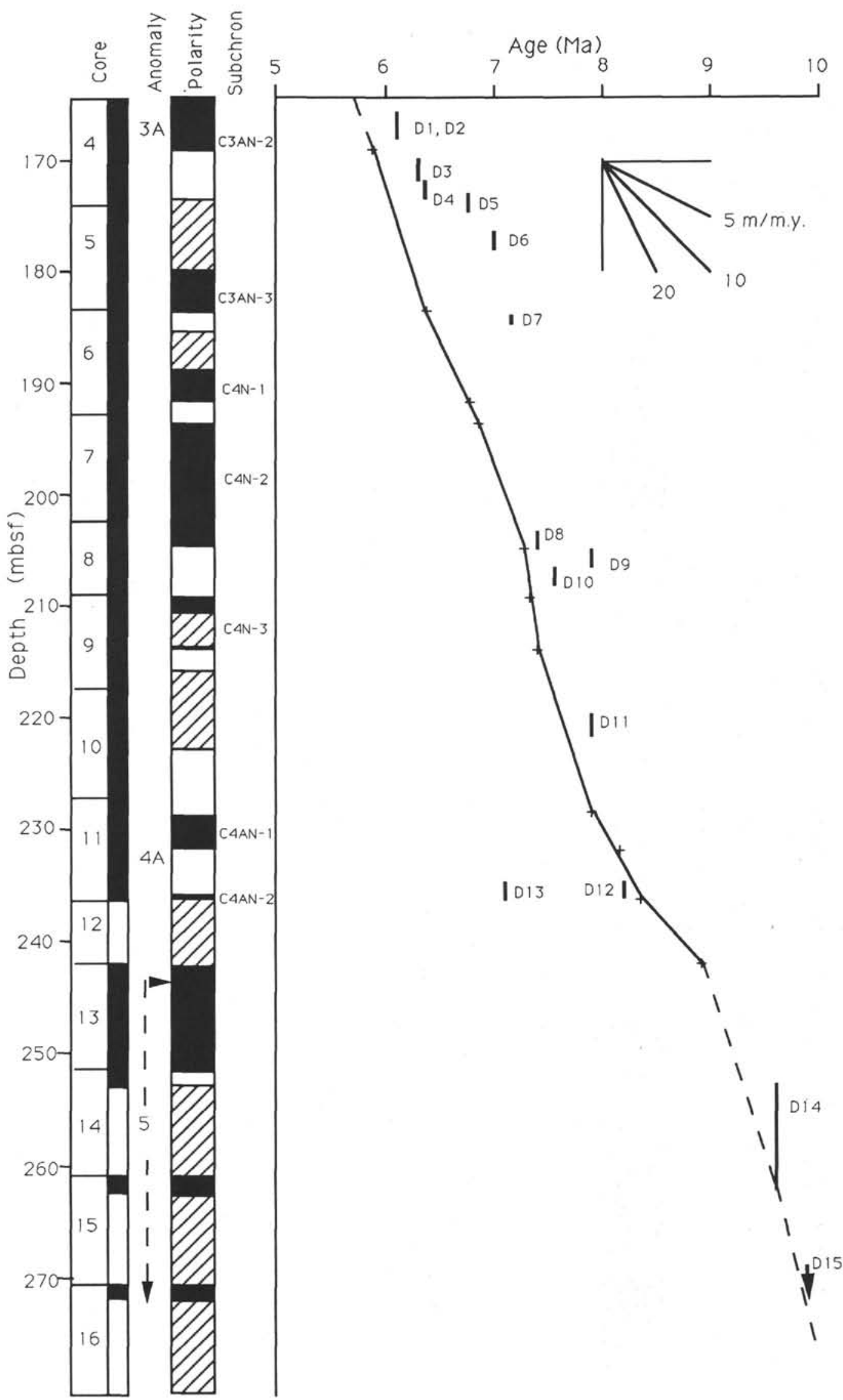

Figure 6. Age vs. depth plot for Hole 746A utilizing the magnetostratigraphic (+) and biostratigraphic events of Table 3. 


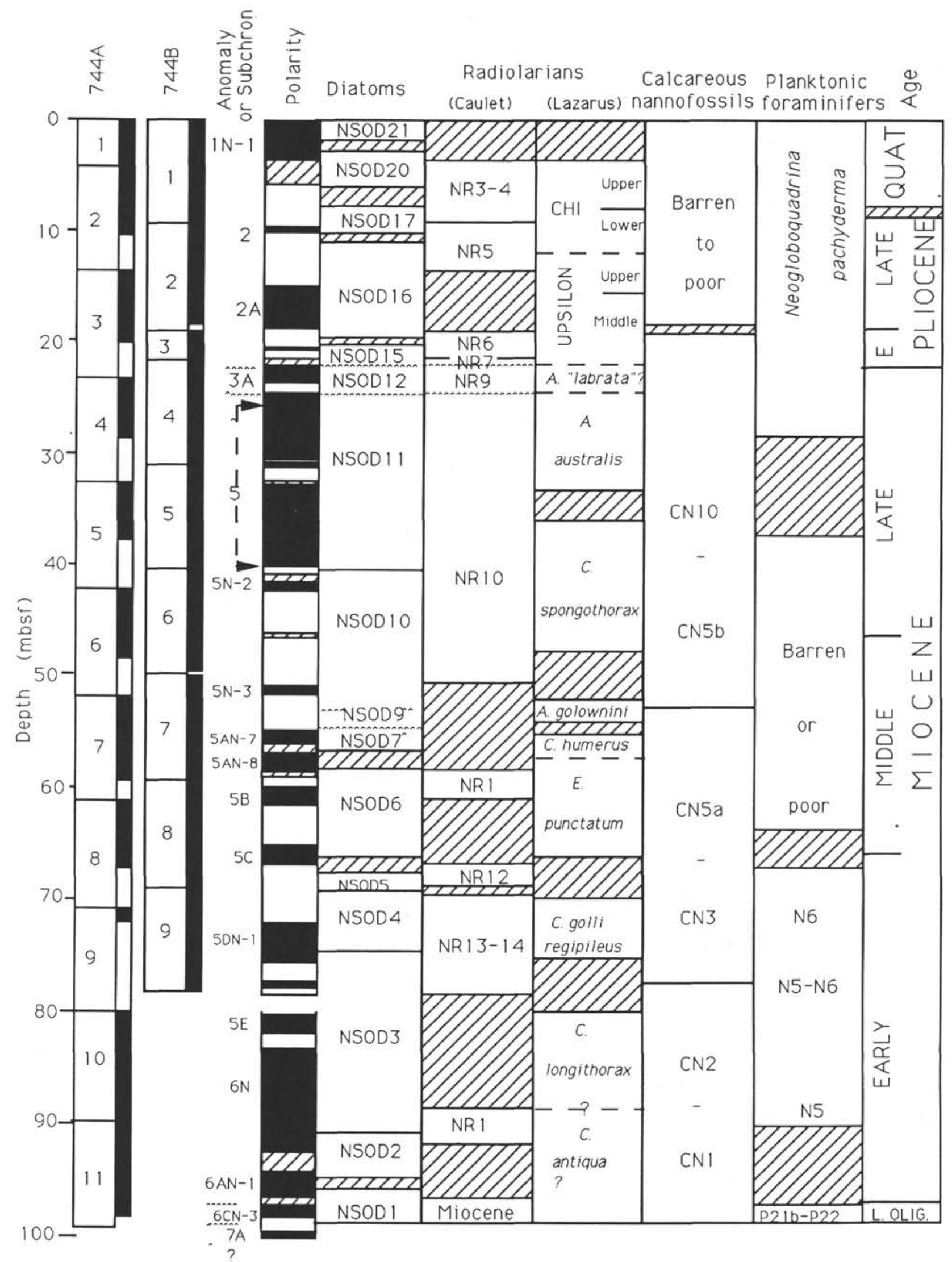

Figure 7. Magnetostratigraphy and biostratigraphy of the upper $100 \mathrm{~m}$ of section cored at Site 744. Diagonal lines shown for intervals of uncertainty or lacking study. 


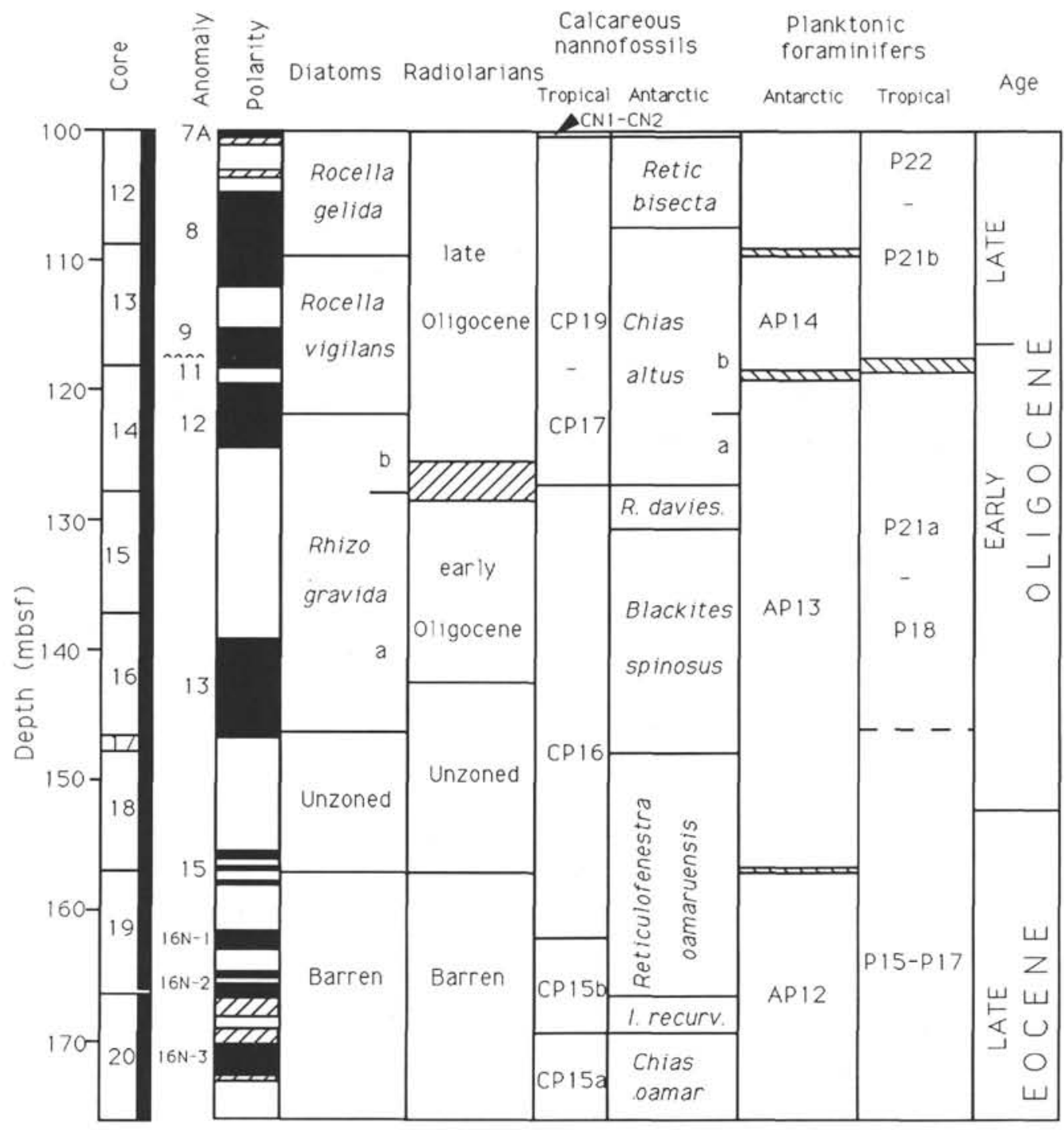

Figure 8. Magnetostratigraphy and biostratigraphy of the lower part of the section cored at Hole 744A. Diagonal lines shown for intervals of uncertainty or lacking study.

malina spissiformia, Bolivina huneri, and Bulimina basistriata var. nuda) have their last occurrences at about 71 mbsf (Schroeder-Adams, this volume), providing further support for such a hiatus.

Post-compaction sedimentation rates average about $10 \mathrm{~m} /$ m.y. for the lowermost middle Eocene to upper Paleocene interval cored between about 205 and 330 mbsf (49.8-62.0 Ma) (Fig. 14). Between 330 and 361 mbsf (62-63.6 Ma) post-compaction sedimentation rate apparently rise to about $23 \mathrm{~m} / \mathrm{m} . \mathrm{y}$. before falling to about $6 \mathrm{~m} / \mathrm{m}$.y. for the lowermost Paleocene (330-377 mbsf). The uppermost Maestrichtian section between 377 and 410 mbsf (66.4-68 Ma) is characterized by post-compaction sedimentation rates averaging about $26 \mathrm{~m} / \mathrm{m}$.y. Detailed magnetobiochronology of the excellent Cretaceous/Tertiary boundary sequence recovered in this interval is summarized by Thierstein et al. (this volume) along with stable isotope and iridium studies.

Tocher's (this volume) documentation of latest Maestrichtian dinoflagellates between 380.46 and 399.74 mbsf adds support to the planktonic foraminiferal and calcareous nannofossil correlations of Figure 12. The age vs. depth curve (Fig. 14) suggests that only the upper Maestrichtian is present above a disconfor- mity at about 410 mbsf that removes the interval from about 68.0 to at least $70.5 \mathrm{Ma}$. Below this hiatus lower Maestrichtian to lower Turonian sediments were encountered between 410 and 480 mbsf, according to calcareous nannofossil (Wei and Thierstein, this volume) and radiolarian (Barron, Larsen, et al., 1989) studies (Fig. 12). Sporadic dinoflagellate assemblages from 430.95 mbsf (Campanian or older) and 477.9 mbsf (Turonian to Coniacian) are supportive of these age assignments.

\section{Site 736}

Site 736, the northernmost site of the Kerguelen Plateau latitudinal transect, lies beneath the modern Antarctic Convergence in $629 \mathrm{~m}$ of water; the convergence, however, may migrate seasonally over as much as $4^{\circ}$ of latitude according to Gordon (1971). A 371-m-thick continuous section of upper Pliocene and Quaternary diatomaceous ooze with a varying component of volcanic, ice-rafted, and other terrigenous material was cored in three holes (Barron, Larsen, et al., 1989). The sequence is dominated by diatoms and, to a lesser degree, radiolarians. Consequently, these groups provide the biostratigraphy for the site (Fig. 15). Interpretation of Southern Ocean diatom zones is rather straightforward (Baldauf and Barron, this volume), but 
Table 5. Age model for Site 744 showing stratigraphic interval of biostratigraphic datum levels, strontium isotope ages, oxygen isotope events $(\mathrm{OX})$, and paleomagnetic subchron boundaries.

\begin{tabular}{|c|c|c|c|c|}
\hline & Datum & $\begin{array}{l}\text { Depth } \\
\text { (mbsf) }\end{array}$ & $\begin{array}{l}\text { Published } \\
\text { age (Ma) }\end{array}$ & Source $^{a}$ \\
\hline \multicolumn{5}{|c|}{ Hole 744B } \\
\hline D1 & LO Actinocyclus ingens & $0.8-9.5$ & 0.62 & 1 \\
\hline PM & $\mathrm{C} 1 \mathrm{~N}-1$ base & $3.80-6.30$ & 0.73 & \\
\hline R1 & LO Cycladophora pliocena & $7.73-9.23$ & 1.73 & 12 \\
\hline PM & $\mathrm{C} 2 \mathrm{~N}$ top & $9.30-9.80$ & 1.66 & \\
\hline PM & $\mathrm{C} 2 \mathrm{~N}-1$ base & $9.80-10.3$ & 1.88 & \\
\hline D2 & LO Thalassiosira kolbei & $9.5-13.0$ & 1.89 & 1 \\
\hline D3 & LO Coscinodiscus vulnificus & $9.5-13.0$ & 2.22 & 2 \\
\hline D4 & LO Cosmiodiscus insignis & $9.5-13.0$ & 2.49 & 1 \\
\hline D5 & FO Coscinodiscus vulnificus & $13.0-19.0$ & 3.1 & 1 \\
\hline PM & $\mathrm{C} 2 \mathrm{AN}-1$ top & $14.8-15.3$ & 2.47 & \\
\hline PM & $\mathrm{C} 2 \mathrm{AN}-3$ base & $18.3-20.8$ & 3.4 & \\
\hline D6 & FO Nitzschia interfrigidaria & $20.83-21.50$ & 3.6 & 3 \\
\hline PM & $\mathrm{C} 3 \mathrm{~N}-1$ top & 20.4 & 3.88 & \\
\hline PM & $\mathrm{C} 3 \mathrm{~N}-1$ base & 20.6 & 3.97 & \\
\hline D7 & FO Nitzschia barronii & $21.50-22.20$ & 4.2 & 3 \\
\hline D8 & FO Nitzschia praeinterfrigidaria & $21.50-22.20$ & 4.5 & 5 \\
\hline D9 & FO Thalassiosira inura & $21.50-22.20$ & 4.6 & 5 \\
\hline D10 & FO Thalassiosira oestrupii & $21.50-22.20$ & 5.1 & 4 \\
\hline D11 & LO Thalassiosira miocenica & $21.50-22.20$ & 5.1 & 4 \\
\hline D12 & LO Thalassiosira praeconvexa & $22.20-23.24$ & 5.8 & 4 \\
\hline PM & C3AN-2 base & $23.3-23.8$ & 5.89 & \\
\hline D13 & FO Thalassiosira miocenica & $23.37-23.90$ & 5.9 & 5 \\
\hline D14 & LO Asteromphalus kennettii & $23.90-24.77$ & $8.6-8.9$ & 5 \\
\hline PM & $\mathrm{C} 5 \mathrm{~N}-1$ top & $24.3-24.8$ & 8.92 & \\
\hline D15 & FO Asteromphalus kennettii & $29.60-31.00$ & 9.6 & 3 \\
\hline R2 & FO Acrosphaera australis & $33.23-36.23$ & 9.7 & 13 \\
\hline R3 & LO Actinoma golownini & $37.6-42.73$ & 10.2 & \\
\hline D16 & LCO Denticulopsis dimorpha & $36.10-37.60$ & 9.9 & 3 \\
\hline PM & $\mathrm{C} 5 \mathrm{~N}-1$ base & $39.8-40.3$ & 10.42 & \\
\hline PM & $\mathrm{C} 5 \mathrm{~N}-2$ top & $40.3-41.92$ & 10.54 & \\
\hline D17 & FO Actinocyclus fryxellae & $40.50-41.10$ & 10.0 & 5 \\
\hline PM & $\mathrm{C} 5 \mathrm{~N}-2$ base & $41.92-42.58$ & 10.59 & \\
\hline R4 & FO Cycladophora spongothorax & $47.23-52.65$ & 12.3 & 13 \\
\hline D18 & LO Denticulopsis praedimorpha & $48.60-50.00$ & 10.4 & 3 \\
\hline D19 & LO Nitzschia denticuloides & $50.00-50.70$ & 10.9 & 3 \\
\hline PM & $\mathrm{C} 5 \mathrm{~N}-3$ top & $50.42-51.39$ & 11.03 & \\
\hline PM & $\mathrm{C} 5 \mathrm{~N}-3$ base & $51.39-52.05$ & 11.09 & \\
\hline ox & G & 52.0 & 12.0 & 18 \\
\hline D20 & FO Denticulopsis dimorpha & $52.20-53.70$ & 11.9 & 3 \\
\hline R5 & FO Actinoma golownini & $52.65-55.23$ & 13.4 & 13 \\
\hline R6 & FO Dendrospyris megalocephalis & $52.65-55.23$ & 12.45 & 14 \\
\hline D21 & LO Actinocyclus ingens var. nodus & $52.65-55.23$ & 12.3 & 3 \\
\hline ox & F & $52.70-53.23$ & 13.4 & 18 \\
\hline D22 & FO Denticulopsis praedimorpha & $53.70-55.20$ & 12.6 & 3 \\
\hline D23 & FO Nitzschia denticuloides & $53.70-55.20$ & 13.5 & 3 \\
\hline ox & $\mathrm{E}$ & $54.73-55.24$ & 14.3 & 18 \\
\hline PM & C5AN-7 top & $54.91-55.38$ & 13.69 & \\
\hline R7 & FO Cycladophora humerus & $55.23-56.73$ & 14.2 & 14 \\
\hline D24 & FCO Denticulopsis hustedtii & $56.7-58.2$ & 14.0 & 3 \\
\hline PM & CSAN-8 base & $58.14-59.22$ & 14.66 & \\
\hline SR & 0.708762 & 59.71 & 15.9 & 16 \\
\hline PM & C5BN-1 top & $59.75-60.38$ & 14.87 & \\
\hline ox & D & 60.1 & 14.9 & 18 \\
\hline SR & 0.708768 & 60.11 & 15.9 & 16 \\
\hline PM & $\mathrm{C} 5 \mathrm{BN}-2$ base & $60.91-61.81$ & 15.27 & \\
\hline D25 & FO $A$. ingens var. nodus & $63.1-64.6$ & 14.9 & 3 \\
\hline SR & 0.708748 & 63.11 & 16.1 & 16 \\
\hline ox & C & 63.55 & 15.3 & 18 \\
\hline D26 & FO Actinocyclus ingens & $64.6-66.1$ & 15.2 & 3 \\
\hline PM & $\mathrm{C} 5 \mathrm{CN}-1$ top & $64.84-65.37$ & 16.22 & \\
\hline ox & B & 65.8 & 15.7 & 18 \\
\hline SR & 0.708690 & 66.11 & 17 & 16 \\
\hline D27 & FO Nitzschia grossepunctata & $66.1-67.6$ & 15.3 & 3 \\
\hline D28 & LO Nitzschia maleinterpretaria & $66.1-67.6$ & 15.6 & \\
\hline R8 & FO Eucyridium punctatum & $66.23-71.3$ & $17.2 ?$ & 14 \\
\hline PM & $\mathrm{C} 5 \mathrm{CN}-3$ base & $66.85-66.95$ & 16.98 & \\
\hline ox & A & 68.74 & 16.6 & 18 \\
\hline D29 & FO Denticulopsis lauta & $69.0-69.58$ & 16 & 4 \\
\hline D30 & FO Denticulopsis maccollumii & $69.0-69.58$ & 16.7 & 5 \\
\hline SR & 0.708661 & 69.59 & 17.6 & 16 \\
\hline R9 & FO Cycladophora golli regipileus & $71.3-80.73$ & $17.2-18.4$ & 14 \\
\hline PM & C5DN-1 top & $71.6-72.4$ & 17.57 & \\
\hline SR & 0.708635 & 74.09 & 18.03 & 16 \\
\hline
\end{tabular}


Table 5 (continued).

\begin{tabular}{|c|c|c|c|c|}
\hline & Datum & $\begin{array}{l}\text { Depth } \\
\text { (mbsf) }\end{array}$ & $\begin{array}{l}\text { Published } \\
\text { age (Ma) }\end{array}$ & Source $^{a}$ \\
\hline \multicolumn{5}{|c|}{ Hole 744B (Cont.) } \\
\hline D31 & FO Crucidenticula nicobarica & $74.08-75.58$ & 17.8 & 4 \\
\hline PM & C5DN-1 base & $75.25-75.76$ & 17.9 & \\
\hline SR & 0.708629 & 77.09 & 18.1 & 16 \\
\hline PM & C5DN-2 top & 77.1 & 18.12 & \\
\hline PM & C5DN-2 base & 77.5 & 18.14 & \\
\hline \multicolumn{5}{|c|}{ Hole $744 \mathrm{~A}$} \\
\hline F1 & LO Globorotalia zealandica & $61.20-62.15$ & 17.6 & 8 \\
\hline F2 & LO Catapsydrax dissimilis & $66.65-70.70$ & 17.6 & 8 \\
\hline F3 & FO Globorotalia praescitula & $80.20-81.15$ & 17.7 & 8 \\
\hline SR & 0.708518 & 81.13 & 18.7 & 16 \\
\hline PM & C5EN base & $81.0-82.4$ & 19.0 & 9 \\
\hline PM & $\mathrm{C} 6 \mathrm{~N}$ top & $83.11-83.26$ & 19.3 & 5 \\
\hline $\mathrm{R} 10$ & FO Cyrtocapsella longithorax & $88.25-89.41$ & $9.1-19.4$ & 14 \\
\hline D32 & FO Thalassiosira fraga & $90.33-91.83$ & 19.9 & 4 \\
\hline SR & 0.708435 & 89.13 & 20.4 & 16 \\
\hline SR & 0.708389 & 92.13 & 21.3 & 16 \\
\hline PM & $\mathrm{C} 6 \mathrm{~N}$ base & $92.48-93.11$ & 20.4 & 5 \\
\hline PM & C6AN-1 top & $94.40-94.86$ & 20.8 & 8 \\
\hline D33 & FO Thalassiosira spumellaroides & $94.83-96.33$ & 22.2 & 4 \\
\hline SR & 0.708391 & 95.13 & 21.3 & 16 \\
\hline D34 & LO Thalassiosira primalabiata & $96.33-97.83$ & 21.7 & 4 \\
\hline PM & C6AN-1 base & $96.46-96.90$ & 21.1 & 6 \\
\hline N1 & LO Reticulofenestra bisecta & $98.4-101.12$ & 24.0 & 10 \\
\hline PM & $\mathrm{C} 6 \mathrm{CN}-3$ & 97.76 & $24.04-24.2$ & \\
\hline SR & 0.708242 & 98.13 & $24.3(24.6)$ & 16 \\
\hline SR & 0.708260 & 99.2 & 24.05 & 17 \\
\hline D35 & FO Thalassiosira spinosa & $99.2-99.8$ & 23.6 & 4 \\
\hline PM & C7AN top & $98.17-99.62$ & 26.3 & 8 \\
\hline PM & C7AN base & $99.98-100.49$ & 26.5 & 6 \\
\hline SR & 0.708163 & 101.67 & $25.9(26.8)$ & 16 \\
\hline PM & $\mathrm{C} 8 \mathrm{~N}-1$ top & $104.5-105.07$ & 26.8 & 6 \\
\hline SR & 0.708156 & 104.67 & $26.0(27.0)$ & 16 \\
\hline SR & 0.708121 & 106.17 & $26.7(28.0)$ & 16 \\
\hline N2 & LO Chiasmolithus altus & $106.12-107.62$ & 25.5 & 10 \\
\hline SR & 0.708145 & 108.7 & 27.36 & 17 \\
\hline F4 & LO Globgerina labiacrassata & $108.7-109.65$ & 28.2 & 9 \\
\hline D36 & FO Rocella gelida & $109.3-110.8$ & 26.2 & 6 \\
\hline PM & $\mathrm{C} 8 \mathrm{~N}-2$ base & $111.56-112.07$ & 27.74 & \\
\hline PM & $\mathrm{C} 9 \mathrm{~N}-1$ top & $115.01-115.58$ & 28.15 & \\
\hline SR & 0.708082 & 115.67 & $28.0(29.0)$ & 16 \\
\hline F5 & LO Chiloguembelina cubensis & $117.15-118.20$ & 30.1 & 8,15 \\
\hline SR & 0.708013 & 118.2 & $30.4(31.1)$ & 16 \\
\hline SR & 0.708014 & 118.2 & 31.13 & 17 \\
\hline PM & $\mathrm{C} 11 \mathrm{~N}$ base & $118.29-118.45$ & 32.06 & \\
\hline F6 & LO Subbotina angiporoides & $118.20-119.1$ & 32.0 & 8,15 \\
\hline PM & $\mathrm{C} 12 \mathrm{~N}$ top & $118.79-119.93$ & 32.46 & \\
\hline D37 & FO Rocella vigilans & $120.3-123.3$ & 32.0 & 7 \\
\hline SR & 0.707960 & 120.67 & $32.2(32.7)$ & 16 \\
\hline D38 & FO Synedra jouseana & $123.3-124.8$ & 33.0 & 7 \\
\hline PM & $\mathrm{C} 12 \mathrm{~N}$ base & $124.30-125.47$ & 32.9 & \\
\hline SR & 0.707911 & 125.17 & $33.9(34.0)$ & 16 \\
\hline N3 & LO Reticulofenestra umbilica & $126.45-127.70$ & 32.2 & 10 \\
\hline SR & 0.707938 & 127.7 & 33.31 & 17 \\
\hline D39 & LO Rhizosolenia oligocenica & $127.7-128.3$ & 33.0 & 7 \\
\hline SR & 0.707916 & 128.67 & $33.8(33.9)$ & 16 \\
\hline SR & 0.707898 & 136.0 & 34.46 & 17 \\
\hline N4 & LO Isthmolithus recurvus & $129.95-131.45$ & 34.8 & 10 \\
\hline SR & 0.707873 & 134.67 & $35.3(35.2)$ & 16 \\
\hline PM & $\mathrm{C} 13 \mathrm{~N}-1$ top & $139.0-139.5$ & 35.29 & \\
\hline SR & 0.707838 & 145.67 & $36.5(36.2)$ & 16 \\
\hline D40 & FO Rhizosolenia oligocenica & $146.7-147.53$ & 35.5 & 7 \\
\hline PM & $\mathrm{C} 13 \mathrm{~N}-2$ base & $146.5-146.77$ & 35.87 & \\
\hline N5 & LO Reticulofenestra oamaruensis & $147.6-148.3$ & 36.0 & 10 \\
\hline SR & 0.707778 & 148.57 & $38.6(37.9)$ & 16 \\
\hline SR & 0.707776 & 150.0 & 37.97 & 17 \\
\hline PM & C15N-1 top & $155.4-155.9$ & 37.24 & \\
\hline F7 & LO Globigerinatheka index & $157.1-158.0$ & 37.1 & 8,15 \\
\hline PM & $\mathrm{C} 15 \mathrm{~N}-2$ base & $157.9-158.3$ & 37.68 & \\
\hline N6 & LO Discoaster saipanensis & $160.86-162.35$ & 36.4 & 11 \\
\hline PM & $\mathrm{C} 16 \mathrm{~N}-1$ top & $161.3-161.9$ & 38.1 & \\
\hline PM & $\mathrm{C} 16 \mathrm{~N}-1$ base & $162.4-163.4$ & 38.34 & \\
\hline PM & $\mathrm{C} 16 \mathrm{~N}-2$ top & $164.3-164.9$ & 38.5 & \\
\hline N7 & FO Reticulofenestra oamaruensis & $166.6-167.35$ & 38.0 & 10 \\
\hline
\end{tabular}


Table 5 (continued).

\begin{tabular}{clccc}
\hline \multicolumn{1}{c}{ Datum } & $\begin{array}{c}\text { Depth } \\
\text { (mbsf) }\end{array}$ & $\begin{array}{c}\text { Published } \\
\text { age (Ma) }\end{array}$ & Source $^{\mathrm{a}}$ \\
\hline Hole 744A (Cont.) & & & \\
SR & 0.707729 & 166.6 & 39.32 & 17 \\
PM & C6N-2 base & $166.68-168.9$ & 38.79 & 10 \\
N8 & FO Isthmolithus recurvus & $168.85-170.35$ & 38.8 & 10 \\
PM & C16N-3 top & $170.0-170.4 ?$ & 38.83 & \\
PM & C16N-3 base & $172.3-173.4$ & 39.24 & \\
\hline
\end{tabular}

a 1 = Ciesielski, 1983; 2 = Weaver and Gombos, 1981; 3 = Gersonde and Burckle, 1990; 4 $=$ Barron, in press; $5=$ Baldauf and Barron, this volume; $6=$ Fenner in Ciesielski, Kristoffersen, et al., 1989; 7 = Harwood et al., 1989; 8 = Berggren et al., 1985a; 9 = Huber, this volume; $10=$ Wei and Wise, $1990 ; 11=$ Wei and Wise, $1989 ; 12=$ Caulet, this volume; 13 = Lazarus, in press; 14 = Abelmann, $1990 ; 15$ = Stott et al., $1990 ; 16$ = Barrera et al., this volume; $17=$ Wei, Wise, Miller, and Feigenson, pers. comm., 1989; $18=$ Woodruff and Chambers, this volume.

Events: R, radiolarian; D, diatom; F, planktonic foraminifer; N, calcareous nannofossil; SR, strontium (ages according to Miller et al., 1988 in parentheses); OX = oxygen isotope events; PM, paleomagnetic. $\mathrm{FO}=$ first occurrence; $\mathrm{FCO}=$ first common occurrence; $L O=$ last occurrence.

the radiolarian stratigraphic interpretation is hampered by the absence and/or sporadic occurrence of deep-water marker species at this relatively shallow-water site (Caulet, this volume). Benthic foraminifers are rare to common throughout the recovered interval (Schroeder-Adams, this volume), and planktonic foraminiferal assemblages are dominated by sinistrally-coiled specimens of Neogloboquadrina pachyderma (Barron, Larsen, et al., 1989). Planktonic foraminifers decrease in abundance below Core 119-736-25X (195 mbsf) and are absent below Core 119-736C-8R (255 mbsf). Calcareous nannofossils are either very rare or absent in sediments recovered from Site 736 , and those nannofossils observed are of limited biostratigraphic value (Wei and Thierstein, this volume).

Diatom and radiolarian datum levels (Table 7) are used in Figure 16 to construct an age vs. depth model for the sediment sequence cored at Site 736. Ages used for these datum levels are from calibration with paleomagnetic stratigraphy elsewhere in the Southern Ocean as well as from the excellent uppermost Miocene to Quaternary paleomagnetic reference section studied at Site 745 (Baldauf and Barron, this volume; Caulet, this volume).

Sediments appear to have accumulated at post-compacted rate of about $95 \mathrm{~m} / \mathrm{m}$.y. during the last $2.5 \mathrm{~m} . \mathrm{y}$. (0-220 mbsf) at Site 736 according to the generalized age vs. depth plot in Figure 16. Certain diatom datum levels (i.e., the last occurrences of Actinocyclus ingens, Rhizosolenia barboi, and Thalassiosira kolbei) appear to have occurred later at Site 736 than elsewhere in the Southern Ocean according to this age model. However, the last common occurrence of $A$. ingens (50.08-53.07 mbsf) and the last consistent occurrence of $R$. barboi (127.9-148.47 mbsf), according to Baldauf and Barron (this volume), fall on the plot of Figure 16 and may better approximate the NSOD 21/NSOD 20 and NSOD 18/NSOD 19 boundaries, respectively, at Site 736, near the northern limit of Antarctic surface waters. The last occurrence of $T$. kolbei appears to be as much as 300,000 yr younger at Site 736 than elsewhere in the Southern Ocean.

Below 220 mbsf the post-compaction sedimentation rate at Site 736 appears to increase dramatically to as much as $250 \mathrm{~m} /$ m.y. according to Figure 16. Seismic stratigraphy at Site 736 suggests that this inflection point may actually be at a depth of about 260 mbsf (Barron, Larsen, et al., 1989), where a lower seismic unit forming mounds and sheet drapes is overlain by an upper seismic unit characterized by a nearly parallel band of reflections. The upper seismic unit coincides with lithologic unit I, a diatom ooze with minor volcanic debris, whereas the lower seismic unit is lithologic unit II, a diatom ooze with minor nannofossil ooze (Barron, Larsen, et al., 1989).

The Antarctic diatoms Cosmiodiscus insignis and Thalassiosira kolbei are present at the base of Hole $736 \mathrm{C}$, implying an age younger than $2.8 \mathrm{Ma}$ according to the correlation of these datum levels with paleomagnetic stratigraphy at Site 745 (Baldauf and Barron, this volume).

\section{Site 737}

Site 737, which lies about $100 \mathrm{~km}$ southeast of Site 736, was drilled in order to continue the collection of a Neogene reference section near the present-day Antarctic Polar Front and to date a regional seismic reflector that was thought to be associated with the rifting of Broken Ridge from the northern Kerguelen Plateau. Seismic studies suggested that the thick uppermost Neogene section sampled at Site 736 was considerably thinner at Site 737 and that better preserved Miocene and early Pliocene microfossil assemblages could be obtained nearer the seafloor at Site 737 (Barron, Larsen, et al., 1989).

A 715.5-m-thick middle Eocene to upper Pliocene section was cored in three holes at Site 737 (Figs. 17 and 18). Below a 1.5-m-thick mixed surficial Quaternary glauconitic sand and diatom ooze (lithologic unit I; Barron, Larsen, et al., 1989) lies an upper Pliocene diatom ooze (lithologic unit II; Barron, Larsen, et al., 1989) assignable to diatom Zone NSOD 16 in Core 119-737A-1H. Diatoms indicate that the surficial hiatus spans the interval from 2.8 Ma to the latest Quaternary (perhaps $<0.2$ Ma) (Baldauf and Barron, this volume), indicating that the younger Pliocene section of Hole 737A is approximately coeval with the oldest Pliocene section at the base of Hole $736 \mathrm{C}$.

The section cored at Site 737 can conveniently be divided into a siliceous Miocene and Pliocene unit above $312.8 \mathrm{mbsf}$ (Fig. 17), and an underlying calcareous Eocene and Oligocene section (Fig. 18). Diatoms and radiolarians (Baldauf and Barron, this volume; Caulet, this volume) form the basis for zoning the Neogene, whereas the Paleogene is zoned from calcareous nannofossils and planktonic foraminifers. Magnetostratigraphy (Sakai and Keating, this volume) records a series of normal polarity events between 11 and about 236 mbsf in Hole 737A, that is assignable to magnetic polarity Subchron $2 \mathrm{AN}-3$ through Chron 4 according to the age model for the Neogene of Site 737 presented in Table 8 and Figure 19.

Post-compaction sedimentation rates average about $60 \mathrm{~m} /$ m.y. between 1.5 and $235 \mathrm{mbsf}(2.8$ and about $6.7 \mathrm{Ma})$ at Site 


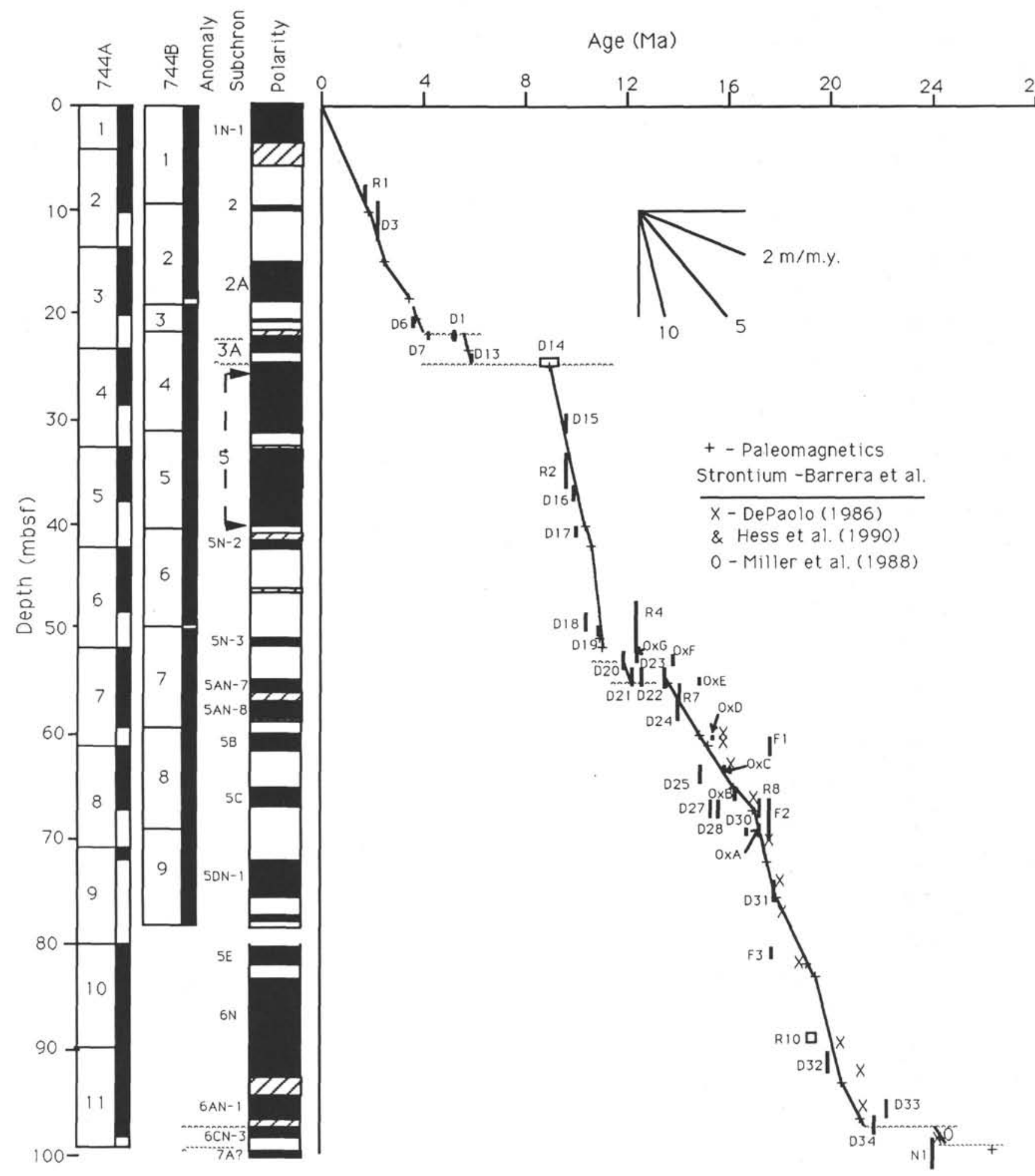

Figure 9. Age vs. depth plot of the Neogene section cored at Site 744 utilizing magnetostratigraphic (+), strontium isotope (X,O), and biostratigraphic events from Table 5. Wavy lines represent hiatuses. Box shown for datums with age range.

737 (Fig. 19). Between 235 and 311 mbsf (6.7 to about $14.0 \mathrm{Ma}$ ) rates appear to have been about $16 \mathrm{~m} / \mathrm{m}$.y., or four times slower than above 235 mbsf (younger than 6.7 Ma). This change in accumulation rates corresponds closely with the upsection replacement of diatom nannofossil ooze of lithologic unit II by diatom ooze of lithologic unit I at 240 mbsf (Barron, Larsen, et al., this volume), indicating an intensification of biosiliceous productiv- ity at about $6.7 \mathrm{Ma}$, probably due to the northward movement of the Polar Frontal Zone across Site 737 in the latest Miocene. Between about 311 and 321 mbsf (14-15 Ma) post-compaction accumulation rates may have fallen to about $6 \mathrm{~m} / \mathrm{m}$.y. (Fig. 7); but poor recovery in the interval and the possibility of one or more hiatuses (Baldauf and Barron, this volume) severely limit interpretations. 


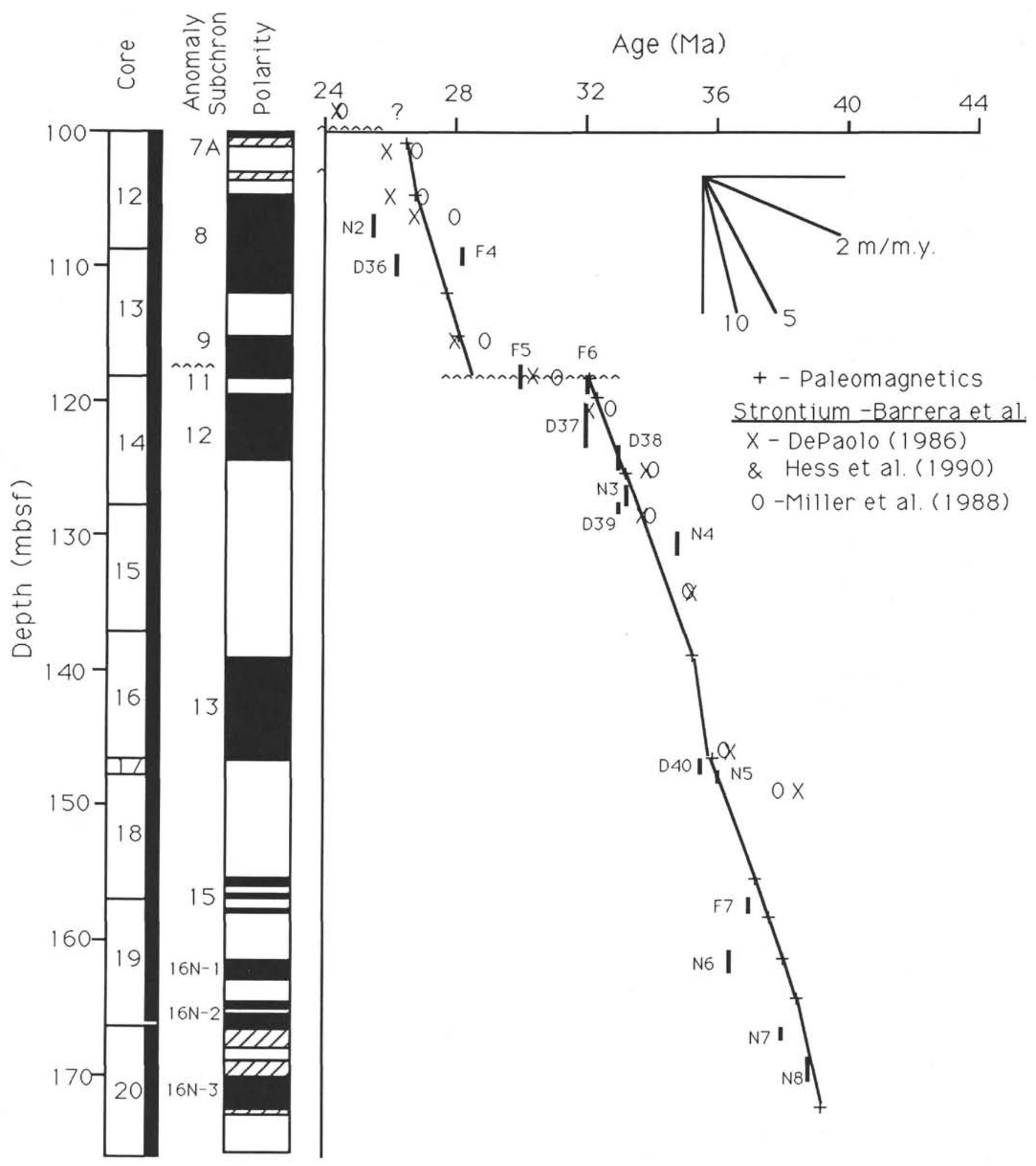

Figure 10. Age vs. depth plot of the Paleogene section cored at Site 744 utilizing magnetostratigraphic (+), strontium isotope (X,O), and biostratigraphic events from Table 5. Wavy lines represent hiatuses. 

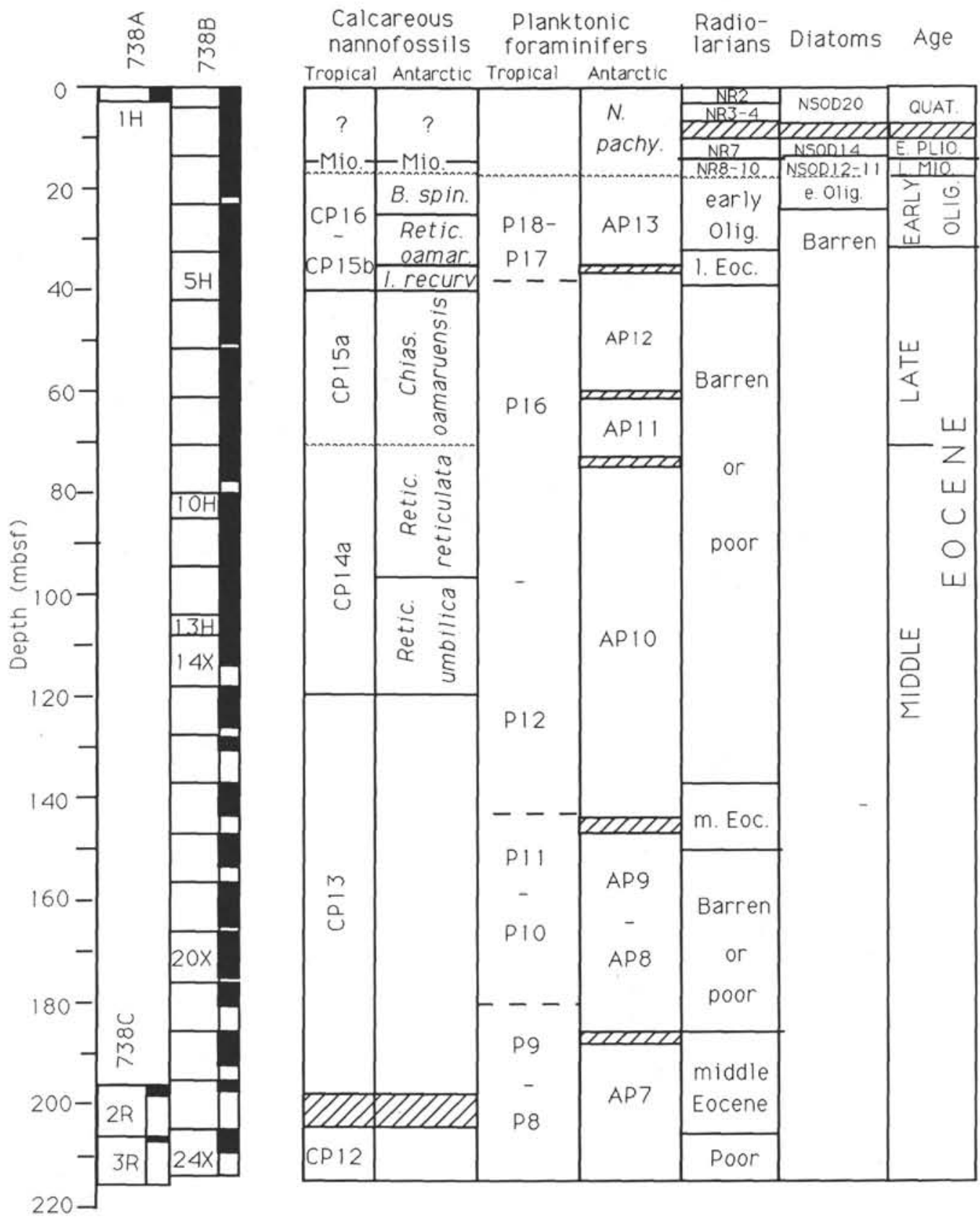

Figure 11. Biostratigraphy of the upper $220 \mathrm{~m}$ of section cored at Site 738. Diagonal lines shown for intervals of uncertainty or lacking study. Wavy lines represent hiatuses.

Radiolarian stratigraphy suggests the possibility of a hiatus or compressed interval between Samples 119-737A-7H-CC and $119-737 \mathrm{~A}-8 \mathrm{H}-\mathrm{CC}(62.0-71.5 \mathrm{mbsf})$, where radiolarian Zone NR7 was not recognized (Fig. 17). Based on radiolarian ages in Hole $745 \mathrm{~B}$, this hiatus would span the interval from about 4.2 to 4.56 $\mathrm{Ma}$ (Caulet, this volume). A hiatus is not plotted at this interval on Figure 19; however, the relatively short (about $1 \mathrm{~m}$ ) interval identified as magnetic polarity Subchron $3 \mathrm{~N}-2(4.10-4.24 \mathrm{Ma})$ and the coincidence of the diatom NSOD 14/15 zonal boundary (event D6 of Table 8 and Fig. 19) with this interval suggest the possibility of a brief hiatus.

A hiatus at about 263 mbsf between Cores 119-737B-5R and 119-737B-6R separates a greenish gray diatom nannofossil ooze from an underlying white to light olive gray diatom nannofossil ooze (Barron, Larsen, et al., 1989). Smear slide studies indicate a downcore change from sediment with varying amounts of diatoms and nannofossils to an almost pure nannofossil ooze $(90 \%$ nannofossils). Diatom stratigraphy suggests that this hiatus spans the interval from at least 8.2 to $9.9 \mathrm{Ma}$ (Baldauf and Barron, this volume) and radiolarian stratigraphy suggests that the upper part of the Cycladophora sponogothorax Zone is missing (Lazarus, in press) (Table 8 and Fig. 19).

A probable hiatus is present between Samples 119-737B-8H$2,57-59 \mathrm{~cm}$, and 119-737B-8H-3, $10 \mathrm{~cm}$ (284.57-285.6 mbsf), based on the extreme compression of the diatom NSOD 9 Zone (11.9-12.6 Ma) in this interval (Fig. 17). A hiatus spanning the interval from about 11.0 to $12.5 \mathrm{Ma}$ is inferred on Figure 19; however, only $3.72 \mathrm{~m}$ was recovered (out of $9.5 \mathrm{~m}$ cored) in Core 


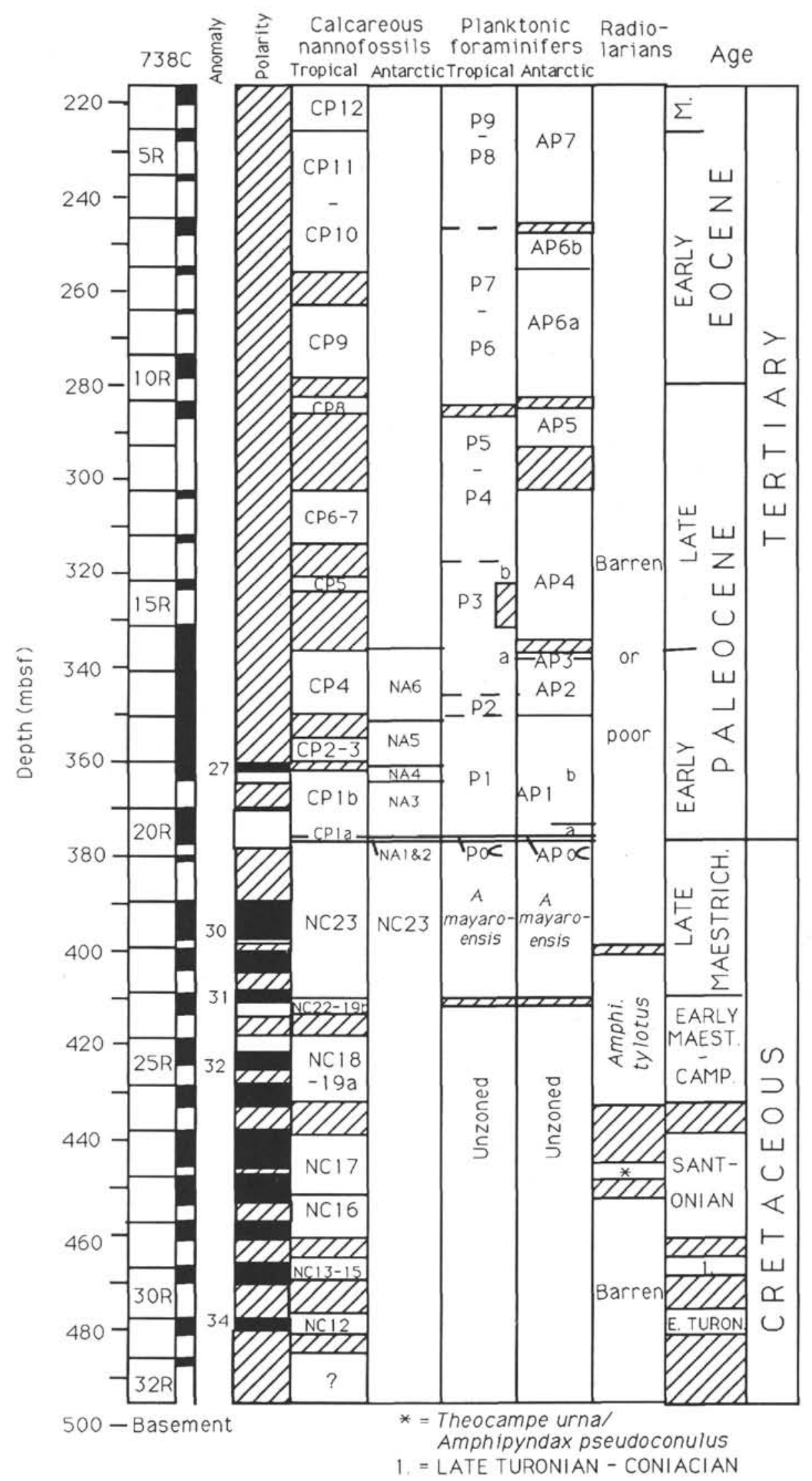

Figure 12. Magnetostratigraphy and biostratigraphy of the lower part of the section cored at Site 738. Diagonal lines shown for intervals of uncertainty or lacking study. 
Table 6. Age model for Site 738 showing stratigraphic interval of biostratigraphic datum levels and paleomagnetic subchron boundaries.

\begin{tabular}{|c|c|c|c|c|}
\hline & Datum & $\begin{array}{l}\text { Depth } \\
\text { (mbsf) }\end{array}$ & $\begin{array}{l}\text { Published } \\
\text { age (Ma) }\end{array}$ & Source ${ }^{a}$ \\
\hline \multicolumn{5}{|c|}{ Hole 738B } \\
\hline D1 & FO Thalassiosira inura & $16.10-16.48$ & 4.8 & 1 \\
\hline D2 & FO Thalassiosira convexa & $16.70-16.93$ & 5.9 & 1 \\
\hline D3 & FO Asteromphalus kennettii & $17.60-19.10$ & 9.6 & 2 \\
\hline N1 & LO Reticulofenestra oamaruensis & $23.66-25.16$ & 36.0 & 7 \\
\hline F1 & LO Globigerinatheka index & $34.90-36.40$ & 37.1 & 4,11 \\
\hline N2 & FO Reticulofenestra oamaruensis & $34.66-36.16$ & 38.0 & 7 \\
\hline N3 & FO Isthmolithus recurvus & $39.26-40.66$ & 38.8 & 7 \\
\hline N4 & FO Chiasmolithus oamaruensis & $69.7-71.16$ & 41.0 & 7 \\
\hline N5 & LO Chiasmolithus solitus & $69.7-71.16$ & 41.4 & 7 \\
\hline N6 & FO Reticulofenestra reticulata & $96.66-98.16$ & 42.1 & 7 \\
\hline N7 & FO Reticulofenestra umbilica & $118.46-119.96$ & 44.6 & 7 \\
\hline F2 & LO Acarinina bullbrooki & $130.89-137.20$ & 43.0 & 4 \\
\hline F3 & FO Globigerinatheka index & $142.62-143.50$ & 45.0 & 4 \\
\hline F3* & Globigerinatheka index & $142.62-143.50$ & 46.2 & 5 \\
\hline F4 & FO Aarinina bullbrooki & $185.40-187.80$ & 47.5 & 5 \\
\hline N8 & FO Nannotetrina fulgens & $196.8-205.26$ & 49.8 & 8 \\
\hline \multicolumn{5}{|c|}{ Hole $738 \mathrm{C}$} \\
\hline N9 & FO Discoaster sublodoensis & $226.26-227.79$ & 52.6 & 4 \\
\hline F5 & FO Acarinina pentacamerata & $255.30-264.10$ & 54.0 & 5 \\
\hline N10 & FO Discoaster lodoensis & $255.79-264.76$ & 55.4 & 4 \\
\hline F6 & FO Acarinina wilcoxensis & $283.40-284.55$ & 56.6 & 5 \\
\hline N11 & FO Discoaster diastypus & $278.9-284.30$ & 56.7 & 9 \\
\hline F7 & FO Planorotalites australiformis & $293.0-302.83$ & 57.5 & 5 \\
\hline N12 & FO Discoaster multiradiatus & $288.2-302.8$ & 59.2 & 8 \\
\hline F9 & LO Subbotina pseudobulloides & $312.3-321.9$ & 61.7 & 4 \\
\hline F10 & FO Igorina pusilla & $321.9-331.6$ & 62.0 & 4 \\
\hline N13 & FO Discoaster mohleri & $312.44-322.0$ & 60.5 & 8 \\
\hline F11 & FO Acarinina praepentacamerata & $333.84-337.0$ & 60.2 & 5 \\
\hline N14 & FO Heliolithus kleinpellii & $322.07-338.30$ & 61.6 & 8 \\
\hline F12 & FO Acarinina mckannai & $337.0-338.50$ & 62.4 & 5 \\
\hline F13 & LO Globoconusa daubjergensis & $350.90-351.59$ & 64.0 & 4 \\
\hline F14 & FO "Planorotalites" imitatus & $350.45-350.9$ & 63.4 & 5 \\
\hline N15 & FO Chiasmolithus bidens & $351.25-351.75$ & 63.2 & 8 \\
\hline N16 & FO Prinsius martinii & $359.5-360.85$ & 63.8 & 10 \\
\hline PM & base $\mathrm{C} 27 \mathrm{~N}$ & $360.87-361.16$ & 63.5 & 4 \\
\hline N17 & FO Chiasmolithus danicus & $364.35-364.85$ & 64.8 & 4 \\
\hline F15 & FO Planorotalites compressus & $372.88-374.10$ & 64.5 & 4 \\
\hline F16 & FO "Morozovella" inconstans & $372.88-374.10$ & 65.1 & 5 \\
\hline N18 & FO Cruciplacolithus tenuis & $376.22-376.55$ & 66.2 & 10 \\
\hline F17 & FO Subbotina pseudobulloides & $376.54-376.64$ & 66.1 & 4 \\
\hline F18 & FO Globoconusa daubjergensis & $376.76-376.85$ & 66.35 & 4 \\
\hline F19 & FO Eoglobigerina fringa & $377.16-377.17$ & 66.35 & 4 \\
\hline F20 & LO Abathomphalus mayaroensis & $377.41-379.92$ & 66.4 & 4 \\
\hline N19 & FO Nephrolithus frequens & $409.14-411.04$ & 68.0 & 10 \\
\hline F21 & FO Abathomphalus mayaroensis & $409.66-411.11$ & 70.5 & 6 \\
\hline PM & base $\mathrm{C} 31 \mathrm{~N}$ & $411.61-412.71$ & 69.4 & \\
\hline PM & top $\mathrm{C} 32 \mathrm{~N}$ & $420.87-421.91$ & 71.37 & \\
\hline $\mathrm{N} 20$ & FO Broinsonia parca & $470.32-477.07$ & 81.9 & 10 \\
\hline
\end{tabular}

a 1 = Baldauf and Barron, this volume; 2 = Gersonde and Burckle, 1990; 3 = Lazarus, 1990; 4 = Berggren et al., 1985a; 5 = Thomas et al., 1990; $6=$ Huber, 1990; $7=$ Wei and Wise, 1990; $8=$ Wei and Wise, 1989; $9=$ Monechi et al., 1985; $10=$ Monechi and Thierstein, 1985; 11 = Stott et al., 1990.

Events: D, diatom; F, planktonic foraminifer; $\mathrm{N}$, calcareous nannofossil; PM, paleomagnetic. $\mathrm{FO}=$ first occurrence; $\mathrm{LO}=$ last occurrence.

119-737B-8H, so it is possible that either a somewhat briefer hiatus is present or that accumulation rates declined markedly during the interval. It is interesting to note that an age-equivalent hiatus was encountered at Site 744.

A major hiatus between Samples 119-737B-11R-1, $103 \mathrm{~cm}$, and 119-737B-11R-2, 80-81 cm (about $312.8 \mathrm{mbsf}$ ), separates lower middle Miocene diatomaceous sediments of lithologic Unit IV from middle Eocene to uppermost Oligocene calcareous claystone of lithologic Unit V (Barron, Larsen, et al., 1989). Diatoms above the hiatus are assigned to Zones NSOD 6-7 and are younger than $15 \mathrm{Ma}$ (Baldauf and Barron, this volume), whereas the last occurrence of the calcareous nannofossil Chias- molithus altus (dated at $25.5 \mathrm{Ma}$ ) coincides with the disconformity (Wei and Thierstein, this volume), suggesting that the entire lower Miocene is missing and the period not represented is over 10.5 m.y. This hiatus occurs at a major acoustic discordance that is recognizable throughout the northern Kerguelen Plateau (Barron, Larsen, et al., 1989; Fröhlich and Wicquart, 1989), and it probably represents a period of subaerial exposure and erosion (Fröhlich and Wicquart, 1989).

The last occurrence of the calcareous nannofossil $C$. altus (event N1) at 320 mbsf provides a minimum age of $25.5 \mathrm{Ma}$ for the upper Oligocene sediments immediately below the hiatus. An isolated occurrence of the diatom Bogorovia veniamini in 


\section{J. A. BARRON ET AL.}

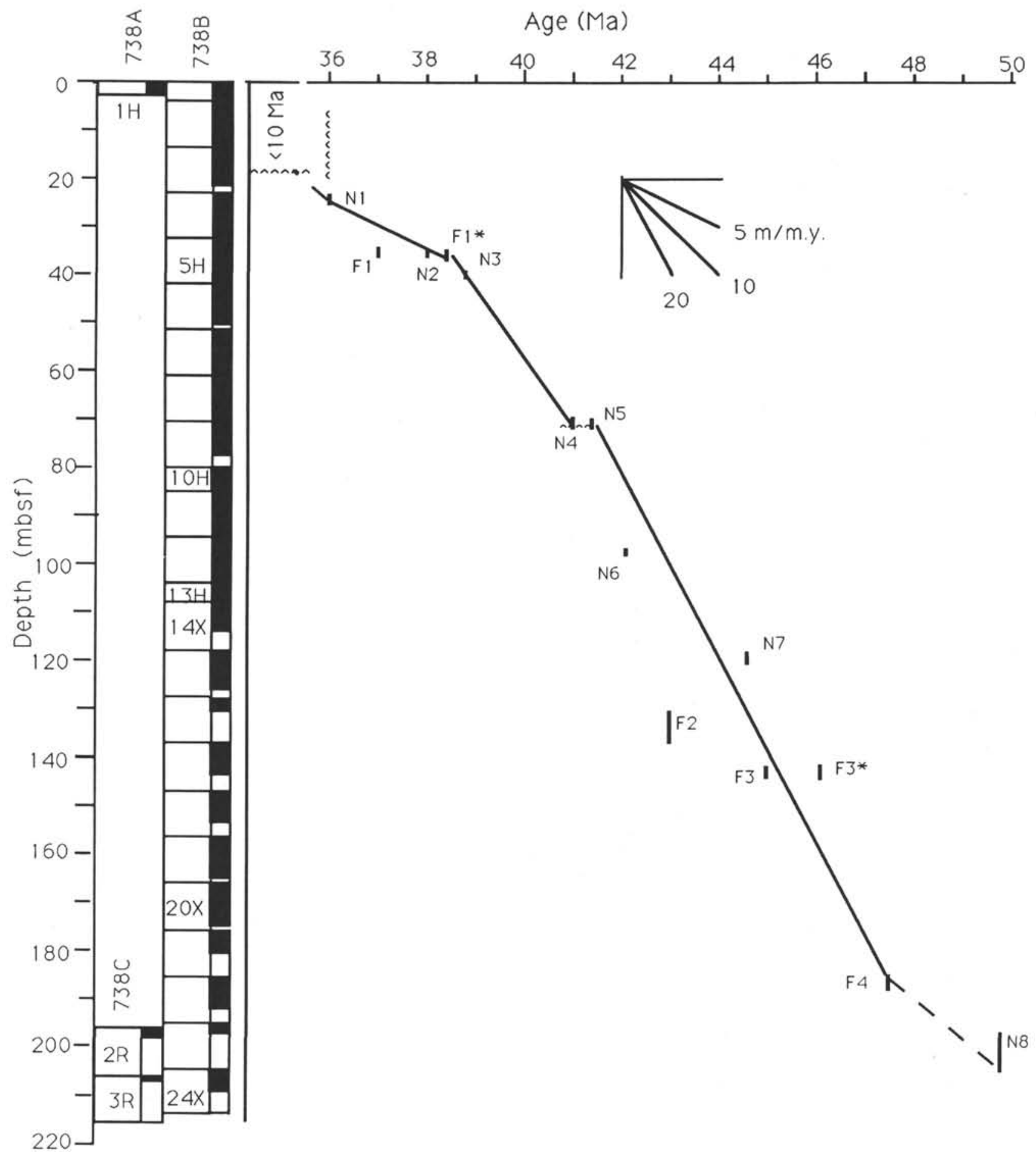

Figure 13. Age vs. depth plot for the middle Eocene to lower Oligocene section cored at Site 738 above $220 \mathrm{~m}$ utilizing the biostratigraphic events of Table 6. Wavy line represents hiatus.

Sample 119-737B-12R-CC (330 mbsf) implies an age younger than $27.7 \mathrm{Ma}$ based on the age of the first occurrence of $B$. veniamini at Site 744 (Baldauf and Barron, this volume) (Table 8).

Biostratigraphic resolution of the calcareous middle Eocene to upper Oligocene section of Hole 737B is rather poor between 320 and 543 mbsf, where individual tropical nannofossil zones cannot be recognized (Wei and Thierstein, this volume) (Fig. 18). The age vs. depth plot for the Paleogene of Site 737 (Fig. 20) suggests that post-compaction sedimentation rates average at least $22 \mathrm{~m} / \mathrm{m} . \mathrm{y}$ between 312.8 and $420 \mathrm{mbsf}$ (about 27-32.2 Ma). Much higher post-compaction sedimentation rates approaching $100 \mathrm{~m} / \mathrm{m}$.y are inferred for the interval between 420 and 550 mbsf (about 32.2-33.4 Ma); however, biostratigraphic resolution is poor in this interval. Between 550 and about 650 mbsf rates of about $20 \mathrm{~m} / \mathrm{m}$.y. are again suggested (Fig. 20) if one assumes that the first occurrence of the calcareous nannofossil Isthmolithus recurvus (event N6) is isochronous with the 38.3 Ma age recorded elsewhere in the Southern Ocean. A dis- 


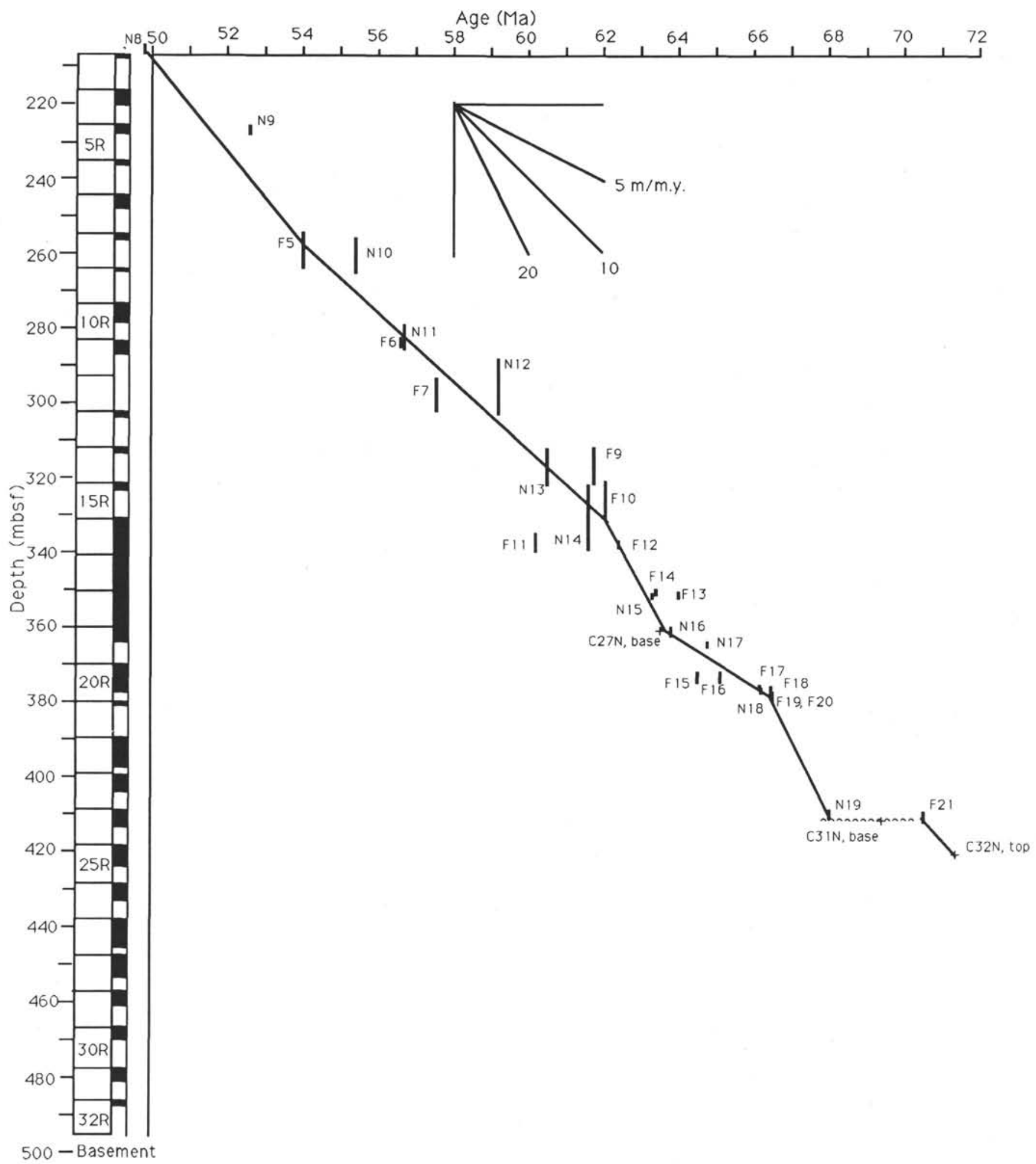

Figure 14. Age vs. depth plot of the upper Maestrichtian to lower middle Eocene section cored at Site 738 utilizing the magnetostratigraphic $(+)$ and biostratigraphic events of Table 6 . Wavy line represents hiatus.

conformity is placed at about 655 mbsf where calcareous nannofossil Subzone CP15a (38.3-41.0 Ma) is extremely compressed (Fig. 18); however, Wei and Thierstein (this volume) remark that Chiasmolithus oamaruensis, the first occurrence of which marks the base of Subzone CP15a, may appear earlier at higher lati- tudes than it does at lower latitudes. The continuation of the 20 $\mathrm{m} / \mathrm{m}$.y. post-compaction sedimentation rate between calcareous nannofossil events N7 (41.0 Ma) and N9 (42.1 Ma) (Fig. 20) supports the inferred hiatus at about $655 \mathrm{mbsf}$, but a lithologic unit contact between calcareous claystone (unit V) and clayey 

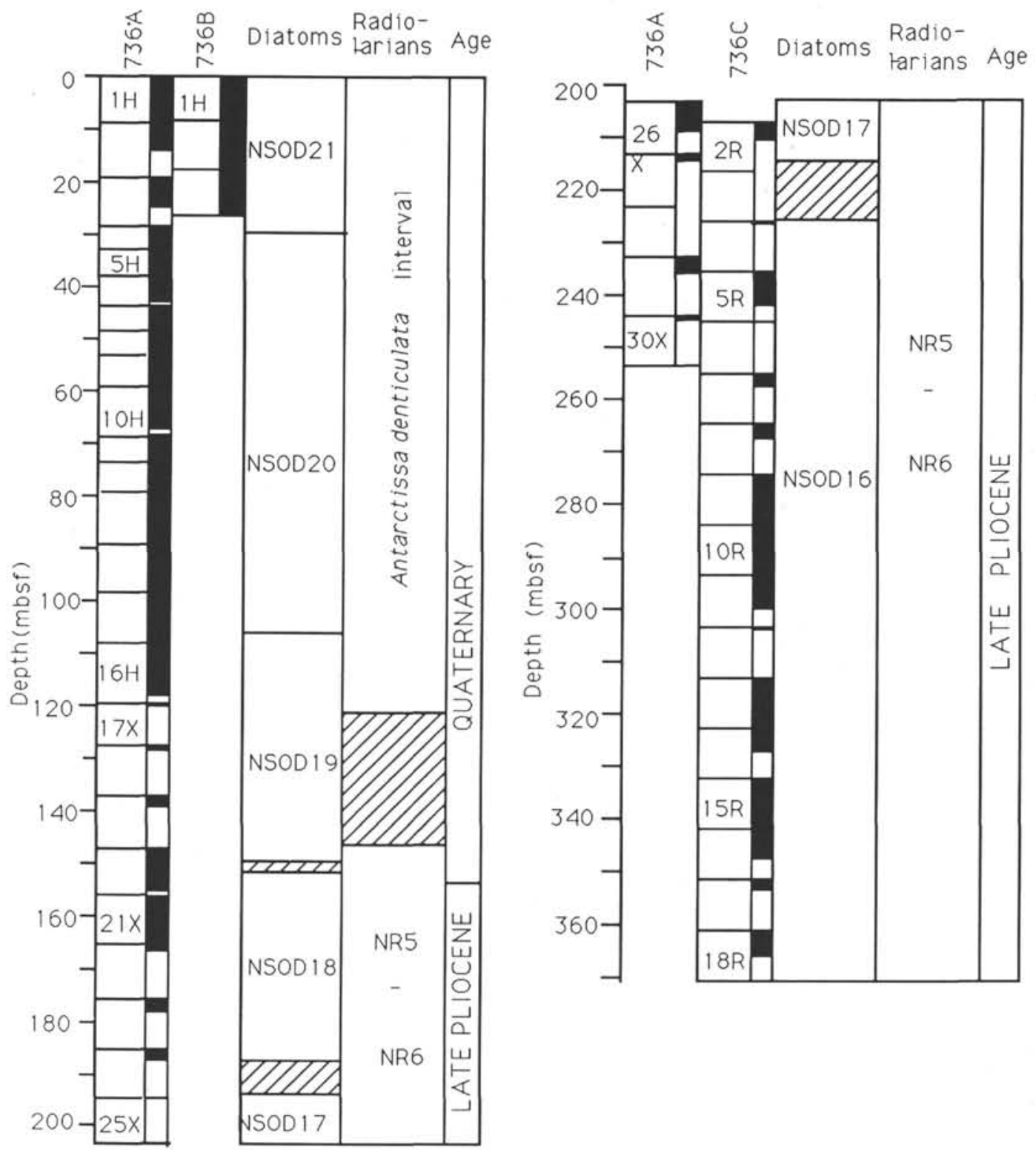

Figure 15. Biostratigraphy of the section cored at Site 736. Diagonal lines shown for intervals of uncertainty or lacking study.

limestone (unit VI) lies slightly below at about 670 mbsf (Barron, Larsen, et al., 1989) and is a more likely place for a disconformity, especially because geotechnical properties also change at that horizon (Barron, Larsen, et al., 1989).

\section{Prydz Bay}

For the most part biostratigraphic control of the five Prydz Bay sites is rather poor (Barron, Larsen, et al., 1989). Nonmarine sediments at inner Prydz Bay Sites 740 and 741 are overlain by a prograding glacial sequence at Sites 742,739 , and 743 (Barron, Larsen, et al., 1989; Hambrey et al., this volume).

\section{Site 740}

A 169-m-thick red bed section of possible Permian or Triassic age was cored at Site 740 located $30 \mathrm{~km}$ off the Antarctic coast (Turner, this volume; Keating, this volume). Site 740 was drilled in order to date the oldest sedimentary sequence overlying basement in Prydz Bay; however, the recovered sediments have failed to yield datable fossil material (Truswell, this volume). This red bed section is overlain by about $33 \mathrm{~m}$ of drilling breccia composed of clasts of gneiss and crystalline igneous rocks, which are probably derived from a Pliocene to Quaternary glacial diamictite. Capping this section is $23 \mathrm{~m}$ of interbedded siliceous ooze and silty clay which is dated by Domack et al. (this volume) as Holocene by ${ }^{14} \mathrm{C}$ using an accelerator massspectrometer.

\section{Site 741}

Site 741 was drilled seaward of Site 740 in order to characterize and date the upper part of a more than $2.5-\mathrm{km}$-thick sequence of sediments that rests on basement in the inner part of Prydz Bay. A 100-m-thick sequence of Lower Cretaceous coalbearing sediments, which is buried beneath about $24 \mathrm{~m}$ of glacial debris, was cored in one hole at the site (Turner and Padley, this volume). Spores recovered from this nonmarine sequence are indicative of a middle to late Albian age (Truswell, this vol- 
Table 7. Age model for Site $\mathbf{7 3 6}$ showing stratigraphic interval of biostratigraphic datum levels.

\begin{tabular}{clccc}
\hline \multicolumn{1}{c}{ Datum } & $\begin{array}{c}\text { Depth } \\
\text { (mbsf) }\end{array}$ & $\begin{array}{c}\text { Published } \\
\text { age (Ma) }\end{array}$ & Source $^{\text {a }}$ \\
\hline Hole 736A & & & & \\
D1 & LO Actinocyclus ingens & $28.57-31.57$ & 0.62 & 1 \\
R1 & LO Antarctissa cylindrica & $48.0-48.5$ & 0.55 & 4 \\
D2 & LO Coscinodiscus elliptopora & $53.07-56.58$ & 0.65 & 1 \\
R2 & FO Mitrocalpis araneafera & $73.5-79.5$ & 0.70 & 5 \\
D3 & LO Rhizosolenia barboi & $105.07-108.0$ & 1.58 & 1 \\
D4 & LO Thalassiosira kolbei & $148.47-152.97$ & 1.89 & 1 \\
R3 & LO Cycladophora pliocena & $127.1-147.0$ & 1.6 & 4 \\
R4 & FO Lithelius nautiloides & $162.4-163.9$ & 1.85 & 5 \\
R5 & FCO Triceraspyris antarctica & $163.9-175.0$ & 1.85 & 5 \\
R6 & FCO Saccospyris antarctica & $175.0-184.6$ & 1.85 & 5 \\
D6 & LO Coscinodiscus vulnificus & $186.79-203.9$ & 2.22 & 2 \\
D7 & LO Cosmiodiscus insignis & $214.76-233.47$ & 2.49 & 1 \\
R7 & LCO Desmospyris spongiosa & $223.2-233.4$ & 2.40 & 4 \\
R8 & LCO Pseudocubus vema & $223.2-233.4$ & 2.40 & 4 \\
Hole 736C & $\quad$ & & & \\
D8 & FO Coscinodiscus vulnificus & $290.57-295.77$ & $2.7-3.0$ & 3 \\
D9 & FO Cosmiodiscus insignis & $>364.87$ & 2.80 & 3 \\
D10 & FO Thalassiosira kolbei & $>364.87$ & 2.80 & 3 \\
\hline
\end{tabular}

a 1 = Ciesielski, 1983; 2 = Gombos and Ciesielski, 1981; 3 = Baldauf and Barron, this volume; 4 = Lazarus, $1990 ; 5=$ Caulet, this volume.

ume). A very minor component of early Tertiary palynomorphs may indicate recycling of these sediments, but Truswell (this volume) argues that these younger forms represent downhole contaminants based on the rather narrow time interval (Coptospora paradoxa Zone) that is represented by the Early Cretaceous spores.

\section{Site 739}

Site 739 is located about $30 \mathrm{~km}$ landward from the shelf edge in Prydz Bay where seismic stratigraphy indicates a transition from generally flat-lying reflectors that characterize the middle parts of the Prydz Bay continental shelf to prograding reflectors that are typical of the outer part of the shelf (Cooper et al., this volume). Drilling at the site was aimed at dating this transition in reflector character with the hope that it represented the transition from preglacial to glacial sediments (Barron, Larsen, et al., 1989). A 486.8-m-thick section of glacial diamictite was cored at Site 739 without reaching preglacial sediments. The biostratigraphy of this sequence will be summarized before that of the more landward Site 742 (Fig. 1) because it forms much of the basis for interpretation of the poorly fossiliferous record at Site 742.

Poor sediment recovery, large intervals barren of microfossils, and sporadic occurrences of reworked specimens hamper the interpretation of the microfossil studies at Site 739. Diatoms provide the most control and are suggestive of a late Quaternary age for Core 119-739C-1R, an early Pliocene (NSOD14-15) age for Cores 119-739C-13R and 119-739C-14R, a late Miocene age for Cores $119-739 \mathrm{C}-18 \mathrm{R}$ through $119-739 \mathrm{C}-24 \mathrm{R}$, and an early Oligocene age for Cores 119-739C-25R through 119-739C-39R (Fig. 21) (Baldauf and Barron, this volume). The early Oligocene diatom assemblages closely resemble assemblage zone B of Harwood (1989) recovered from the CIROS-1 drill hole in the western McMurdo Sound area of west Antarctica (Baldauf and Barron, this volume; D. M. Harwood, pers. comm., 1989), which is assigned an age of $34.5-36.0 \mathrm{Ma}$ by Harwood et al. (1989). Calcareous nannofossil stratigraphy supports the diatom age assignments, although assemblages are very sporadic, show very low diversity and may be reworked (Wei and Thierstein, this volume). The presence of Isthmolithus recurvus in Samples
119-739C-28R-1, 30-32 cm, and 119-739C-30R-1, 108-110 cm, is suggestive of a late Eocene to early Oligocene age of 38.8$34.8 \mathrm{Ma}$ (Wei and Thierstein, this volume). Dinoflagellate assemblages recovered from Cores 119-739C-41R, 119-739C-47R, and 119-739C-51R (331, 386, and 426 mbsf, respectively) belong to a provincial Antarctic flora of Eocene to early Oligocene age according to Truswell (this volume), but they occur together with reworked Permian pollen and Cretaceous spores.

Strontium isotope studies, however, on molluscan shells from the interval from 183.2 to $282.63 \mathrm{mbsf}$, an interval assigned to the early Oligocene based on diatoms and the late Eocene to early Oligocene based on calcareous nannofossils, yield late Oligocene to earliest Miocene ages ranging from 29.95 to $23.4 \mathrm{Ma}$ (Macdougall et al., this volume) (Fig. 21). These strontium isotope studies are discounted in favor of the diatom and calcareous nannofossil biostratigraphy for the following reasons:

1. An upsection trend toward younger ages that typifies the five lower strontium isotope samples is countered by relatively random ages in the upper five sample measurements.

2 . Even if the upper five measurements are discarded, the resulting post-compaction sedimentation rate of $7.5 \mathrm{~m} / \mathrm{m}$.y. (Macdougall et at., this volume) is much too low for glaciomarine sediments deposited on the continental shelf in front of an ice sheet (Harwood et al., 1989; Hambrey et al., this volume).

3. Although X-ray-diffraction studies were completed on some of the molluscan shells, scanning electron microscope studies are also needed to ensure that recrystalization of the original aragonite of the molluscan shell did not reset strontium values.

4. Prydz Bay glacial sediments contain high amounts of igneous and metamorphic debris (Hambrey et al., this volume; Jenkins and Alibert, this volume) that could cause anomalous strontium values in the pore waters. Studies of the Site 739 pore waters by Macdougall et al. (this volume) do show anomalously high values of strontium.

\section{Site 742}

The biostratigraphy and magnetostratigraphy of the 316-mthick section cored at Site 742 is presented in Figure 22. Site 742 


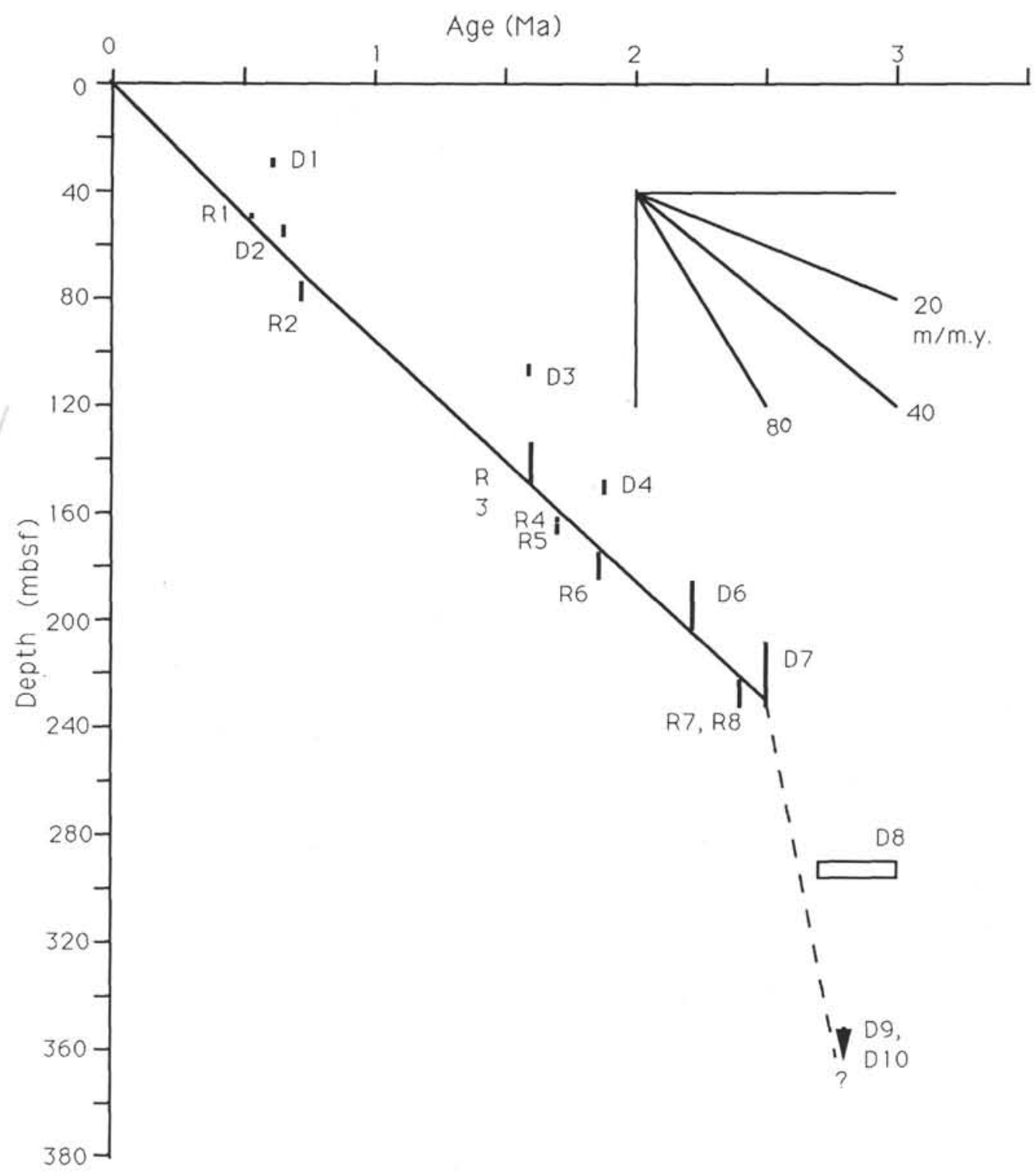

Figure 16. Age vs. depth plot of the section cored at Site 736 utilizing the biostratigraphic events of Table 7.

was cored in a hope that the base of the thick glacial sequence sampled at Site 739 could be reached. Consequently, Site 742 was chosen landward from Site 739 where seismic stratigraphy could trace reflectors at the bottom of Hole $739 \mathrm{C}$ closer to the seafloor and where the top of an underlying acoustic unit lies relatively close (about $300 \mathrm{~m}$ ) to the seafloor (Barron, Larsen et al., 1989; Cooper et al., this volume). Unfortunately, safety considerations limited coring at Site 739 to a maximum depth of $316 \mathrm{~m}$. Nevertheless, over $130 \mathrm{~m}$ of section underlying the section sampled at the base of Hole 739C (Cooper et al., this volume) was cored in the lower part of Hole 742A (172.5-316 mbsf) (Fig. 22).

In general, microfossil recovery was very poor from Hole 742A. A 56-cm-thick diatomite recovered between 127.7 and 128.3 mbsf contains late Pliocene diatoms that are correlative with Zone NSOD18 (2.22-1.89 Ma). This constrains the age of the overlying section to the latest Pliocene to Quaternary.

Logging unit 2 of Barron, Larsen, et al. (1989), between 138.8 and 172.8 , is barren of microfossils, but logging and seismic stratigraphy suggests that it is equivalent to logging unit 2 of Site 739, which contains late Miocene and early Pliocene dia- toms. These intervals in Holes $739 \mathrm{C}$ and $742 \mathrm{~A}$ are unique in terms of organic geochemistry in that they contain mature hydrocarbons (MacDonald et al., this volume; Kvenvolden et al., this volume), further arguing for correlation. Thus, a tentative age of late Miocene to early Pliocene is inferred for the interval between 138.8 and 172.8 mbsf in Hole 742A.

Microfossil control in the glacial diamictites of lithologic unit V (Barron, Larsen, et al., 1989) from 172.8 to 304.3 mbsf of Hole $742 \mathrm{~A}$ is limited to poorly-preserved Eocene to early Oligocene diatoms in Core 119-742A-20R, a middle Eocene to Oligocene calcareous nannofossil assemblage characterized by $R e$ ticulofenestra daviesii in Core 119-742A-27R (Wei and Thierstein, this volume), and provincial Eocene to early Oligocene dinoflagellates in Cores 119-742A-20R, 119-742A-22R, and 119742A-33R (Truswell, this volume; Tocher in Barron, Larsen, et al., 1989). Reworked Permian pollen and long-ranging Cretaceous to Tertiary spores and pollen are also present in the dinoflagellate samples (Truswell, this volume).

Lithologic unit VI (304.3-136.0 mbsf), which consists of interbedded siltstones and claystones as well as minor diamictites, also contains the provincial Eocene to early Oligocene dinofla- 
BIOCHRONOLOGIC AND MAGNETOCHRONOLOGIC SYNTHESIS OF LEG 119 SEDIMENTS

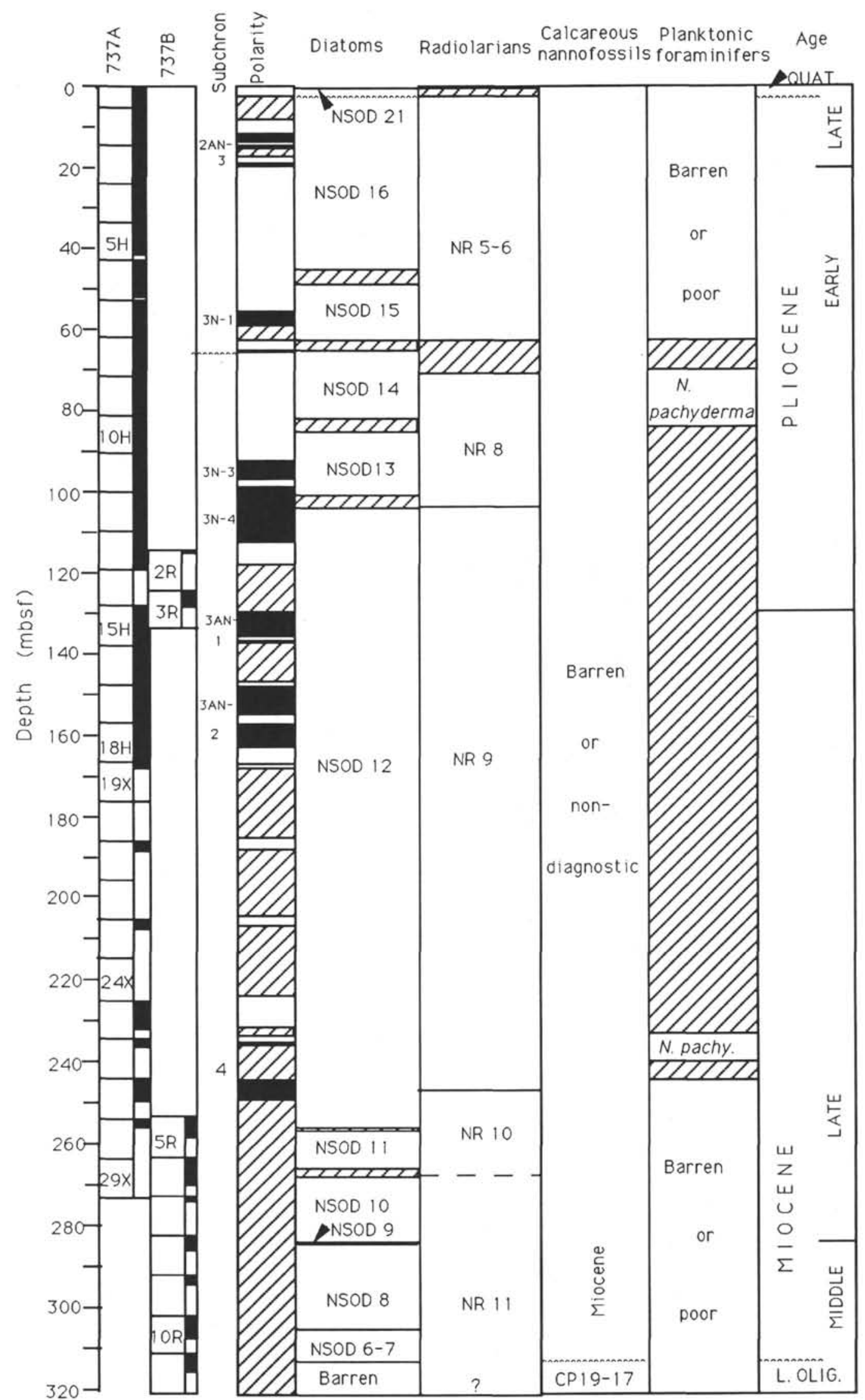

Figure 17. Magnetostratigraphy and biostratigraphy of the Neogene section of Site 737. Diagonal lines shown for intervals of uncertainty or lacking study. Wavy lines represent hiatuses. 


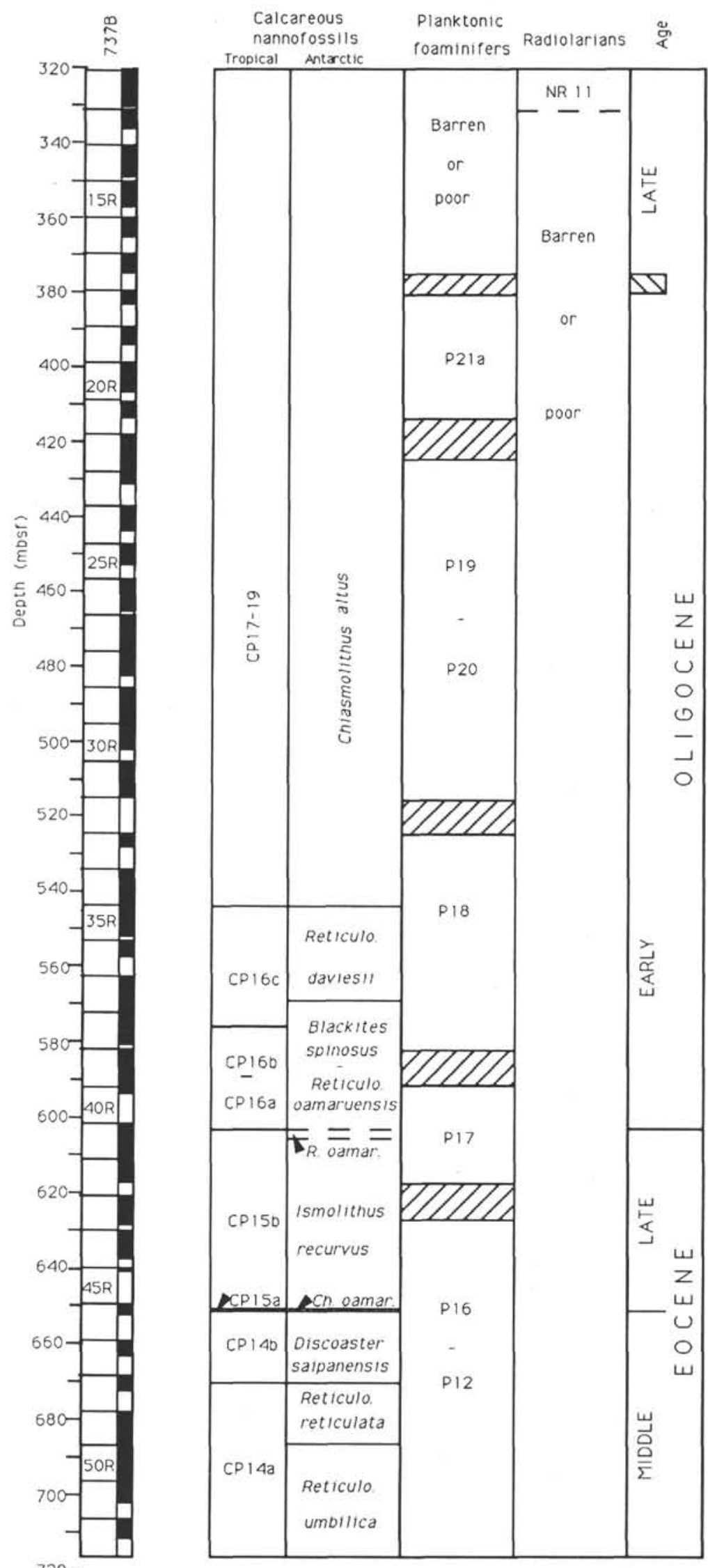

Figure 18. Biostratigraphy of the Paleogene section of Site 737. Diagonal lines shown for intervals of uncertainty or lacking study. 
Table 8. Age model for Site 737 showing stratigraphic interval of biostratigraphic datum levels and paleomagnetic subchron boundaries.

\begin{tabular}{|c|c|c|c|c|}
\hline & Datum & $\begin{array}{l}\text { Depth } \\
\text { (mbsf) }\end{array}$ & $\begin{array}{l}\text { Published } \\
\text { age (Ma) }\end{array}$ & Source ${ }^{a}$ \\
\hline \multicolumn{5}{|c|}{ Hole $737 \mathrm{~A}$} \\
\hline D1 & FO Nitzschia kerguelensis & $2.07-4.9$ & $1.9-2.0$ & 1 \\
\hline D2 & LO Thalassiosira torokina & $2.07-4.9$ & 2.1 & 1 \\
\hline PM & C2AN-2 top? & $11.08-11.75$ & 2.99 & \\
\hline D3 & FO Thalassiosira kolbei & $11.57-14.50$ & 2.8 & 1 \\
\hline PM & C2AN-2 base? & $13.75-14.07$ & 3.08 & \\
\hline D4 & FO Nitzschia weaveri & $16.57-21.07$ & 3.0 & 1 \\
\hline PM & C2AN-3 top & $18.93-19.16$ & 3.18 & \\
\hline PM & C2AN-3 base? & $19.81-20.1 ?$ & 3.4 & \\
\hline D5 & FO Nitzschia interfrigidaria & $43.57-49.57$ & 3.6 & 2 \\
\hline PM & $\mathrm{C} 3 \mathrm{~N}-1$ top & $55.2-55.62$ & 3.86 & \\
\hline PM & $\mathrm{C} 3 \mathrm{~N}-1$ base & $59.64-63.0$ & 3.97 & \\
\hline D6 & FO Nitzschia barronii & $62.0-65.57$ & 4.0 & 1 \\
\hline PM & $\mathrm{C} 3 \mathrm{~N}-2$ top & $64.78-65.38$ & 4.1 & \\
\hline PM & $\mathrm{C} 3 \mathrm{~N}-2$ base & $65.38-66.38$ & 4.24 & \\
\hline D7 & FO Nitzschia praeinterfrigidaria & $78.07-81.0$ & $4.4-4.5$ & 1 \\
\hline D8 & FO Thalassiosira inura & $81.0-86.07$ & 4.47 & 2 \\
\hline PM & $\mathrm{C} 3 \mathrm{~N}-3$ top & $91.89-92.54$ & 4.4 & \\
\hline PM & $\mathrm{C} 3 \mathrm{~N}-3$ base & $97.3-98.5$ & 4.47 & \\
\hline PM & $\mathrm{C} 3 \mathrm{~N}-4$ top & $98.5-99.3$ & 4.57 & \\
\hline R2 & FCO Prunopyle titan & $100.0-100.4$ & $4.6-4.67$ & 4 \\
\hline D9 & FO Thalassiosira oestrupii & $100.0-102.07$ & 5.1 & 3 \\
\hline R3 & LO Stichocorys peregrina & $101.9-103.4$ & 4.8 & \\
\hline PM & $\mathrm{C} 3 \mathrm{~N}-4$ base & $106.5-107.12$ & 4.77 & \\
\hline DI0 & LO Thalassiosira miocenica & $111.57-119.0$ & 5.1 & 3 \\
\hline D11 & FO Thalassiosira praeoestrupii & $119.0-135.07$ & 5.4 & 3 \\
\hline PM & C3AN-1 top & $118.05-129.77$ & 5.35 & \\
\hline D12 & LO Thalassiosira praeconvexa & $154.07-157.0$ & 5.8 & 3 \\
\hline PM & $\mathrm{C} 3 \mathrm{AN}-2$ base & $166.86-167.55$ & 5.89 & \\
\hline D13 & FO Thalassiosira miocenica & $167.07-176.2$ & 5.8 & 3 \\
\hline PM & $\mathrm{C} 4 \mathrm{~N}-1$ top & $234.58-235.58$ & 6.7 & \\
\hline D14 & LCO Denticulopsis hustedtii & $234.97-244.10$ & 6.3 & 1 \\
\hline D15 & FO Nitzschia marina & $247.67-253.8$ & 7.4 & \\
\hline D16 & FO Cosmiodiscus intersectus & $247.67-253.8$ & 7.9 & 2 \\
\hline \multicolumn{5}{|c|}{ Hole 737B } \\
\hline D17 & FO Thalassiosira torokina & $255.2-258.2$ & $7.9-8.2$ & 1 \\
\hline D18 & FO Thalassiosira burckliana & $258.5-263.77$ & 8.2 & 3 \\
\hline D19 & LCO Denticulopsis dimorpha & $258.5-263.77$ & 9.9 & 2 \\
\hline R4 & LCO Actinomma golownini & $263.2-263.5$ & 10.3 & 5 \\
\hline D20 & FO Actinocyclus fryxellae & $265.27-268.27$ & 10.0 & 1 \\
\hline R5 & FO Lychnocanium grande & $266.7-268.2$ & $7.9-8.2$ & 4 \\
\hline R6 & FCO Cycladophora sponothorax & $268.2-272.9$ & 12.3 & 5 \\
\hline D21 & LO Denticulopsis praedimorpha & $273.52-282.5$ & 10.4 & 2 \\
\hline D22 & LO Nitzschia denticuloides & $273.52-282.5$ & 10.9 & 2 \\
\hline D23 & FO Denticulopsis praedimorpha & $282.8-283.6$ & 12.6 & 2 \\
\hline D24 & LO Nitzschia grossepunctata & $294.26-301.8$ & 13.5 & 2 \\
\hline D25 & LO Actinocyclus ingens var. nodus & $302.37-305.37$ & 12.3 & 2 \\
\hline D26 & FO Nitzschia denticuloides & $305.37-311.50$ & 13.5 & 2 \\
\hline D27 & FCO Denticulopsis hustedtii & $305.37-311.50$ & 14.0 & 2 \\
\hline D28 & FO Denticulopsis hustedtii & $305.37-311.50$ & 14.2 & 2 \\
\hline D29 & FO Denticulopsis hyalina & $312.53-313.8$ & 15.0 & 3 \\
\hline N1 & LO Chiasmolithus altus & $312.0-313.8$ & 25.5 & 6 \\
\hline D30 & FO Bogorovia veniamini & $>330.8$ & 27.7 & 1 \\
\hline F1 & LO Chiloguembelina cubensis & $369.4-379.1$ & 30.1 & 8,9 \\
\hline F2 & LO Subbotina angiporoides & $417.7-427.4$ & 32.0 & 8,9 \\
\hline N2 & LO Reticulofenestra umbilica & $543.30-552.9$ & 33.2 & 6 \\
\hline N3 & LO Isthmolithus recurvus & $567.45-568.95$ & 34.8 & 6 \\
\hline N4 & LO Discoaster saipanensis & $602.01-603.62$ & 36.4 & 7 \\
\hline N5 & FO Reticulofenestra oamaruensis & $605.42-605.99$ & 38.0 & 6 \\
\hline N6 & FO Isthmolithus recurvus & $649.30-650.20$ & 38.3 & 6 \\
\hline N7 & FO Chiasmolithus oamaruensis & $651.01-658.60$ & 41.0 & 6 \\
\hline N8 & LO Chiasmolithus solitus & $671.36-677.60$ & 41.4 & 6 \\
\hline N9 & FO Reticulofenestra reticulata & $686.5-687.01$ & 42.1 & 6 \\
\hline
\end{tabular}

${ }^{a} 1$ = Baldauf and Barron, this volume; 2 = Gersonde and Burckle, 1990; 3 = Barron, in press; $4=$ Caulet, this volume; $5=$ Lazarus, 1990; $6=$ Wei and Wise, 1990; $7=$ Wei and Wise, 1989; 8 = Berggren et al., 1985a; Stott et al., 1990. 


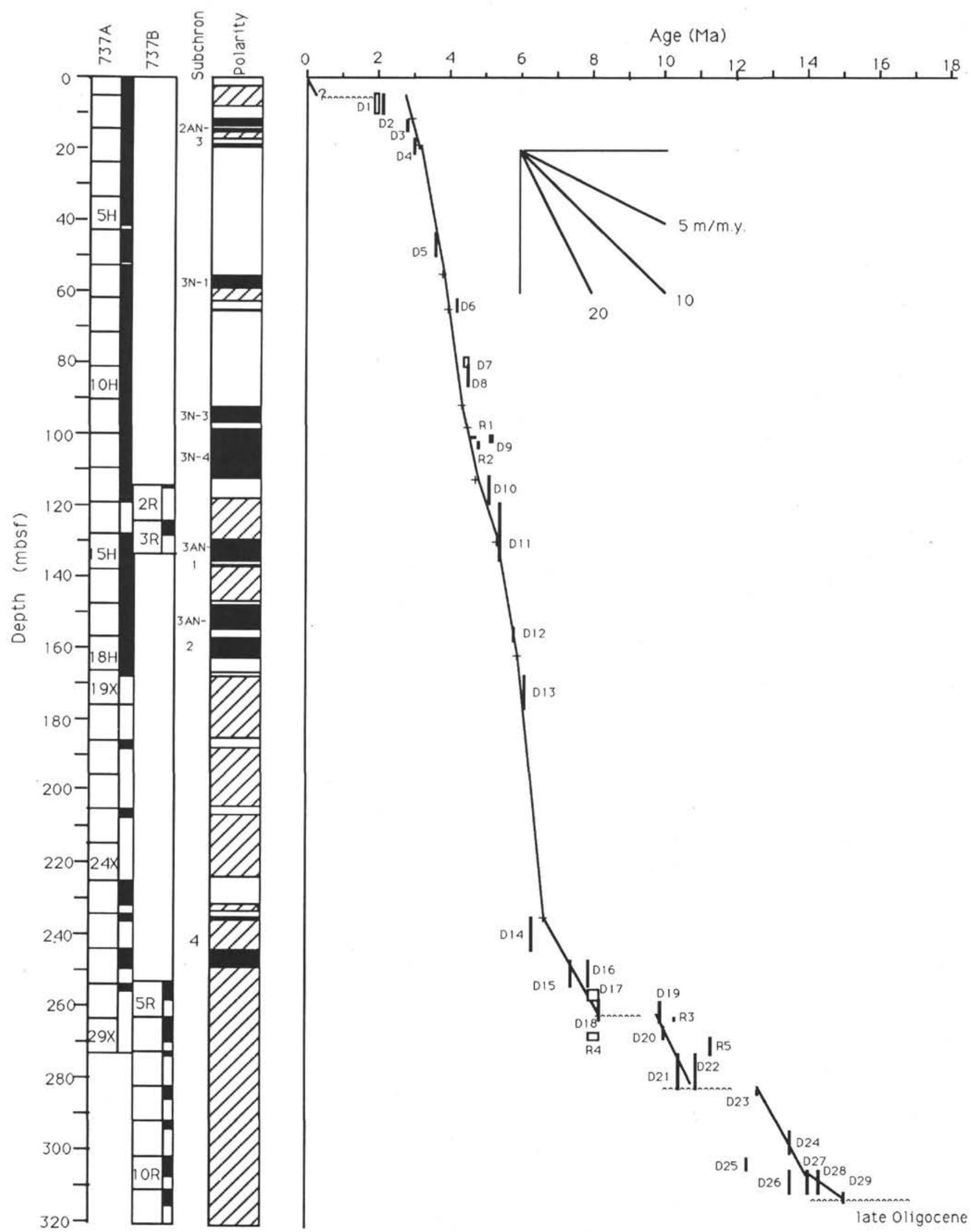

Figure 19. Age vs. depth plot of the Neogene of Site 737 utilizing the magnetostratigraphic $(+)$ and biostratigraphic events of Table 8 . Wavy lines represent hiatuses. 


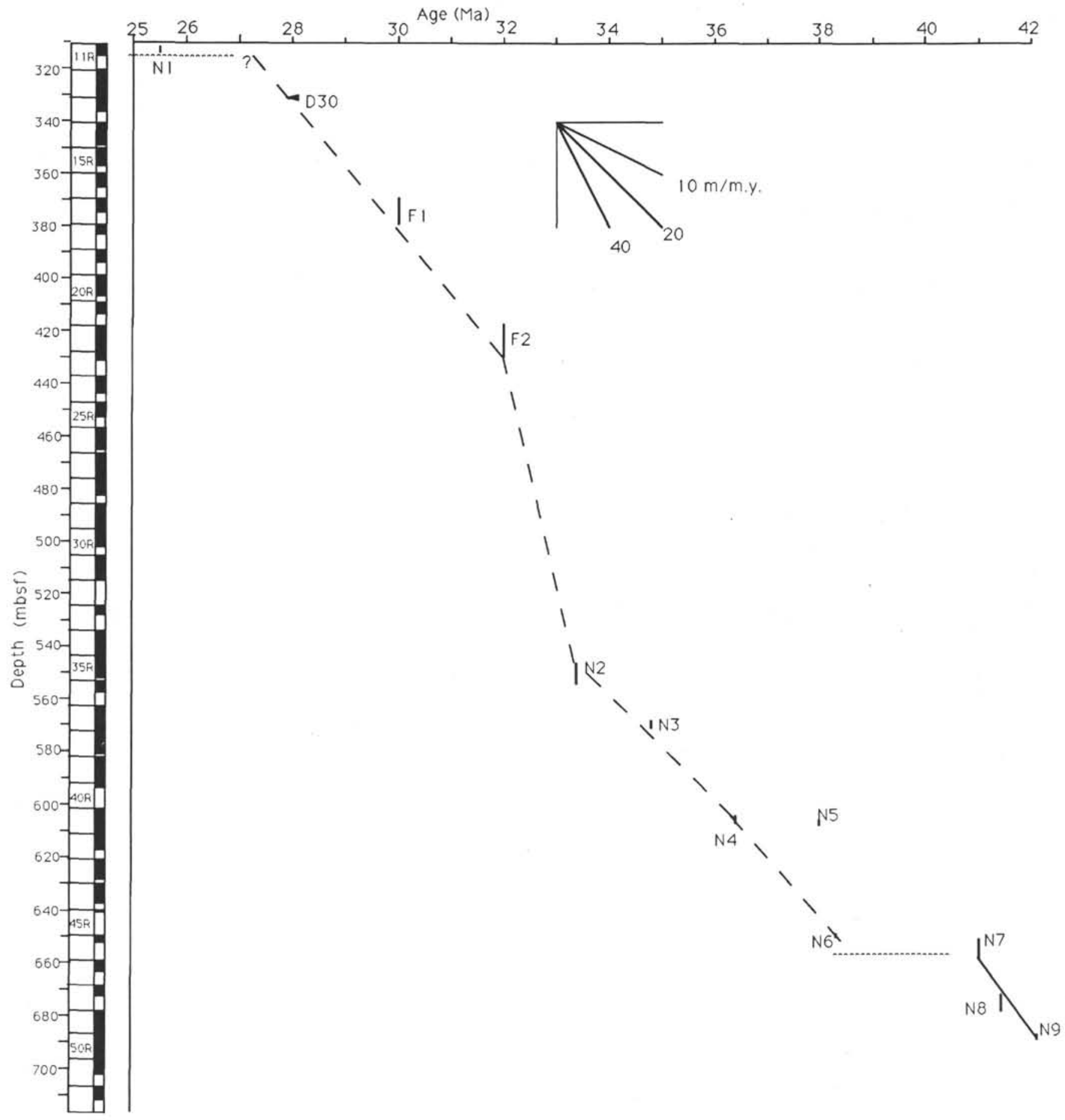

Figure 20. Age vs. depth plot of the Paleogene section of Site 737 utilizing the biostratigraphic events of Table 7. Wavy line represents a hiatus.

gellate assemblage, but Sample 742A-34R-6, $116 \mathrm{~cm}$ (315 mbsf), from lithologic subunit VIC bears only Late Cretaceous spores and pollen (Tocher in Barron, Larsen, et al., 1989; Truswell, this volume) (Fig. 22). Although Truswell (this volume) assigns this basal sample to the Late Cretaceous, the sediments are obviously deformed (folded) and appear to have been emplaced either as a mass flow or as material rafted at the base of a moving glacier (Barron, Larsen, et al., 1989, p. 413).

The 172.7-312.68 mbsf interval of Hole 742A yields a seemingly excellent magnetic polarity record consisting of a mostly normal polarity sequence interrupted by eight short reversals (Sakai and Keating, this volume) (Fig. 22). Shipboard cryogenic measurements were duplicated by shorebased study of discrete samples employing alternating field demagnetization. Assuming that the diatoms, calcareous nannofossils, and dinoflagellates of this interval are not reworked, one must look for this distinctive magnetic polarity signature within the Eocene and early Oligocene. The sequence lies below the lower Oligocene sediments recovered between 173 and 318 mbsf in Hole $739 \mathrm{C}$ (Fig. 21), according to seismic stratigraphy (Cooper et al., this 
Hole $739 \mathrm{C}$

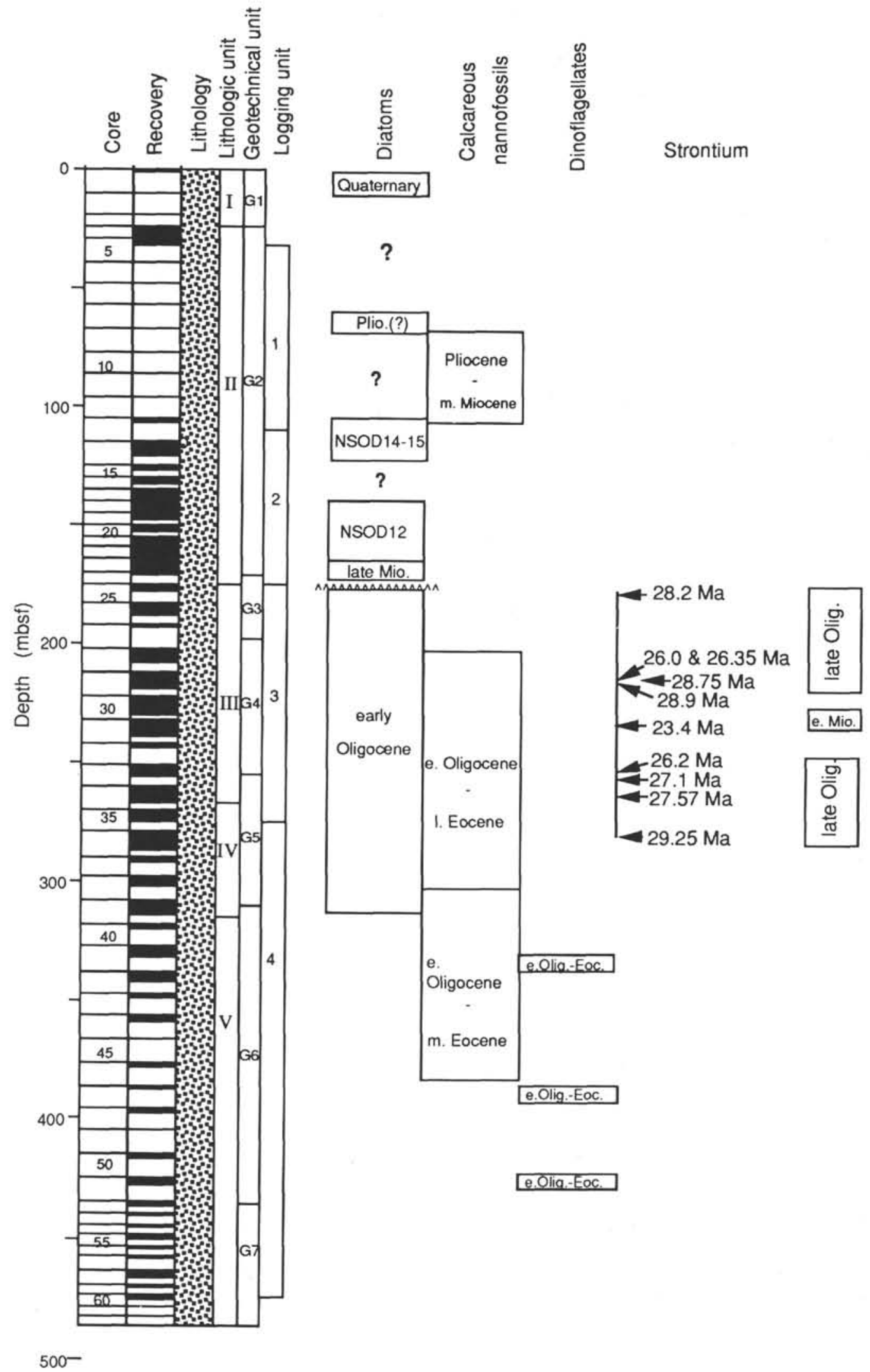

Figure 21. Biostratigraphy and strontium isotope stratigraphy (Macdougall et al., this volume) of Site 739 showing lithologic, geotechnical, and logging units of Barron, Larsen, et al. (1989). Wavy line represents hiatus. 


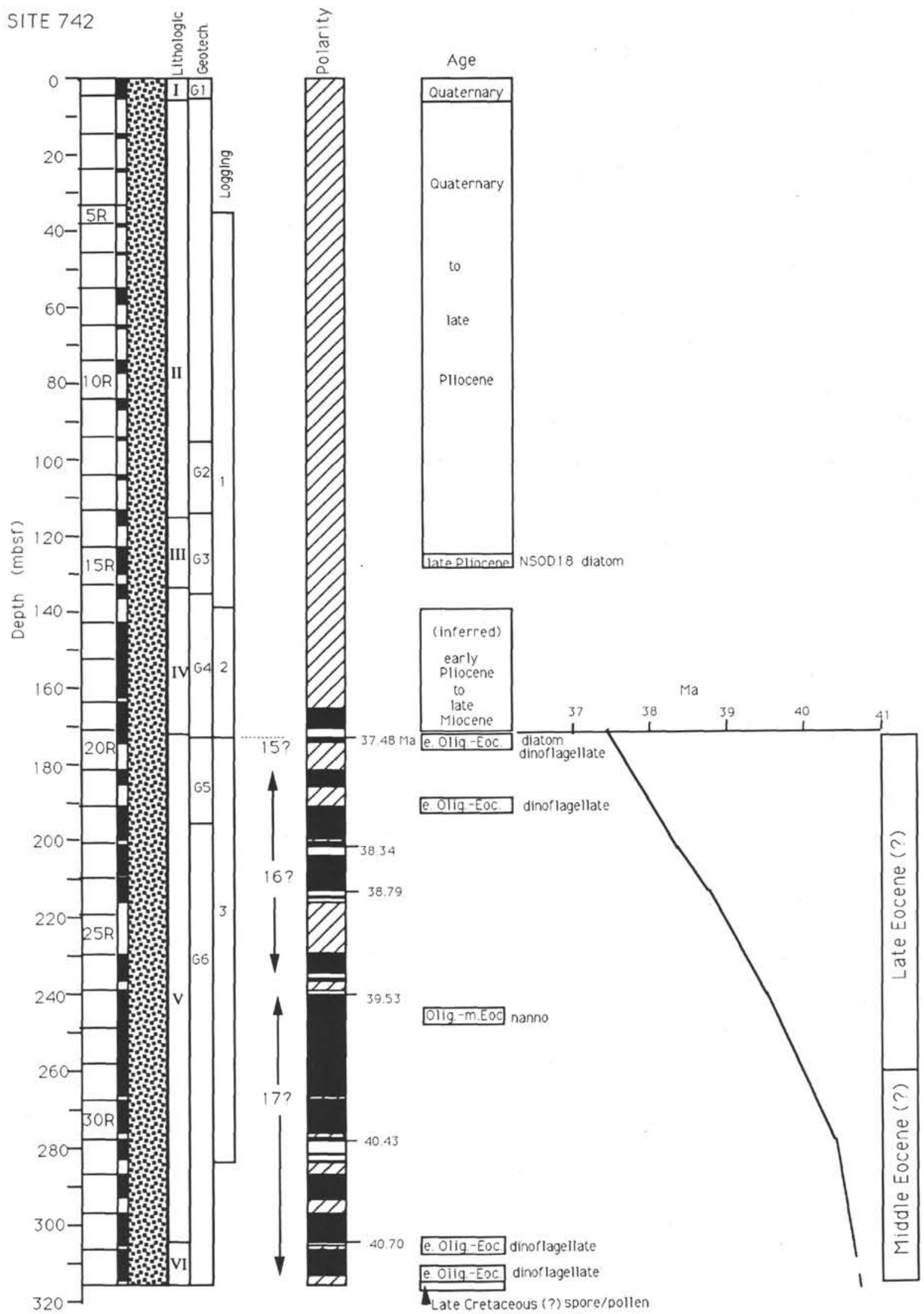

Figure 22. Biostratigraphy and magnetostratigraphy of Site 742 showing lithologic, geotechnical, and logging units of Barron, Larsen, et al. (1989). A speculative age vs. depth plot for the lower part of the section is included on the lower right. 
volume), so it should be Eocene or earliest Oligocene in age. Comparison with the geomagnetic time scale for the middle Eocene to earliest Oligocene interval (Fig. 2B) reveals only one interval, Chrons 15 to 18 , which is characterized by mostly normal polarity with numerous short reversals. A comparison of the downcore polarity $\log$ with the sequence from Subchron $\mathrm{C} 15 \mathrm{~N}-2$ to Subchron $\mathrm{C} 17 \mathrm{~N}-3(37.46-40.8 \mathrm{Ma})$ is made in Figure 22 , which shows relatively uniform post-compaction sedimentation rates of about $35 \mathrm{~m} / \mathrm{m}$.y., quite comparable with the sedimentation rates obtained for proximal glaciomarine sediments from the paleomagnetically dated middle part of the sequence cored in the CIROS-1 drill hole (Harwood et al., 1989).

\section{Site 743}

Site 743 on the upper continental slope was drilled in order to study the Quaternary glacial history of Prydz Bay and to study the types of sediments and sedimentary processes on a slope seaward of a shelf dominated by glacial sediments. Recovery was poor in the 98.1-m-thick section cored at Site 743 and consisted of mostly of diamictons along with silty clay and moderately-well sorted gravels and sand (Barron, Larsen, et al., 1989). The biostratigraphy of Hole $743 \mathrm{~A}$ is extremely poor. The presence of the planktonic foraminifer Neogloboquadrina pachyderma in Cores 119-743A-2H, 119-743A-4H, and 119-743A-5H suggests a late Miocene to Quaternary age, whereas the observation of the diatom Nitzschia kerguelensis in samples from Core $119-743 \mathrm{~A}-4 \mathrm{H}$ further restricts the age of that core to the late Pliocene to Quaternary. Presumably, the entire sequence cored in Hole $743 \mathrm{~A}$ is Quaternary in age, based on the high sedimentation rates expected on the upper slope (Barron, Larsen, et al., 1989; Cooper et al., this volume).

\section{SUMMARY}

The 22 holes drilled at 11 sites during ODP Leg 119 constitute a latitudinal transect from $49.40^{\circ} \mathrm{S}$ to $68.76^{\circ} \mathrm{S}$ in the southern Indian Ocean including both the Kerguelen Plateau (Sites 736-738, 744-746) and the continental shelf and slope of east Antarctica in Prydz Bay (Sites 739-743). Excellent magnetostratigraphic and biostratigraphic control are present for the past 10 m.y. at deep-water Sites 745 and 746 and for the past 39 m.y. at Site 744 on the southern Kerguelen Plateau. Site 738 on the southern Kerguelen Plateau contains a nearly complete Turonian to lower most Oligocene section that contains a continuous sequence across the Cretaceous/Tertiary boundary (see Thierstein et al., this volume); however, magnetostratigraphy is limited to the moderately well-recovered Upper Cretaceous and lowermost Paleocene. Northern Kerguelen Sites 736 and 737 form a composite middle Eocene to Quaternary section located near the present-day Antarctic Polar Front.

Diatoms and radiolarians offer the best biostratigraphic control for the Neogene, whereas calcareous nannofossils and planktonic foraminifers are most useful in the Upper Cretaceous and Paleogene. Leg 119 studies have allowed refinement of the magnetobiochronologic framework for the Cenozoic of the Southern Ocean.

The biochronology of the nonmarine and glaciomarine sediments recovered from Prydz Bay is limited. Outer continental shelf Site 739 contains the best sequence of diatoms and calcareous nannofossils, with early Oligocene, late Miocene, early Pliocene, and late Pliocene to Quaternary assemblages identified. The glacial sediments of Site 742 are poorly fossiliferous, but sporadic control from diatoms, calcareous nannofossils, and dinoflagellates taken with magnetostratigraphy indicate that the section cored at Site 742 ranges as old as latest middle Eocene and late Eocene. Lower Cretaceous nonmarine sediments were recovered from inner Prydz Bay Site 741, but sediments from the innermost Site 740 failed to yield microfossils.

\section{ACKNOWLEDGMENTS}

We acknowledge Elisabeth Fourtanier for help with compiling the biostratigraphic and magnetostratigraphic data on tables and drafting of figures. We are also grateful to Ellen Thomas and Rainer Gersonde for sending copies of the Leg 113 biostratigraphic syntheses. This manuscript benefitted from the reviews of Katharina Perch-Nielsen-von Salis, Peter Webb, Ellen Thomas, and Richard Z. Poore.

\section{REFERENCES}

Abelmann, A., 1990. Oligocene to middle Miocene radiolarian stratigraphy of southern high latitudes from Leg 113, Sites 689 and 690, Maud Rise. In Barker, P. F., Kennett, J. P., et al., Proc. ODP, Sci. Results, 113: College Station, TX (Ocean Drilling Program), 675708

Aubry, M.-P., Berggren, W. A., Kent, D. V., Flynn, J. J., Klitgord, K. D., Obradovich, J. D., and Prothero, D. R., 1988. Paleogene geochronology: an integrated approach. Paleoceanography, 3:707742.

Barker, P. F., and Burrell, J., 1982. The influence upon Southern Ocean circulation, sedimentation, and climate of the opening of the Drake Passage. In Craddock, C. (Ed.), Antarctic Geoscience: Madison (Univ, of Wisconsin), 377-385.

Barron, J. A., 1985. Late Eocene to Holocene diatom biostratigraphy of the equatorial Pacific Ocean, Deep Sea Drilling Project Leg 85. In Mayer, L. A., Theyer, F., et al., Init. Repts. DSDP, 85: Washington (U.S. Government Printing Office), 413-456.

in press. Neogene diatom datum levels in the equatorial and North Pacific. In Saito, T., and Ishizaki, K. (Eds.), The Centenary of Japanese Micropaleontology: Tokyo (Univ. Tokyo Press).

Barron, J., Larsen, B., et al., 1989. Proc. ODP, Init. Repts., 119: College Station, TX (Ocean Drilling Program).

Berggren, W. A., Kent, D. V., and Flynn, J. J., 1985. Jurassic to Paleogene: Part 2. Paleogene geochronology and chronostratigraphy. In Snelling, N. J. (Ed.), The Chronology of the Geological Record. Geol. Soc. London Mem., 10:141-195.

Berggren, W. A., Kent, D. V., Flynn, J. J., and Van Couvering, J. A., 1985. Cenozoic geochronology. Geol. Soc. Am. Bull., 96:14071418.

Berggren, W. A., Kent, D. V., and Van Couvering, J. A., 1985. The Neogene: Part 2. Neogene geochronology and chronostratigraphy. In Snelling, N. J. (Ed.), The Chronology of the Geological Record. Geol. Soc. London Mem., 10:211-260.

Berggren, W. A., and Miller, K. G., 1988. Paleogene tropical planktonic foraminiferal biostratigraphy and magnetobiochronology. Micropaleontology, 34:362-380.

Blow, W. H., 1979. The Cainozoic Foraminifera (Vols. 1-3): Leiden (E. J. Brill).

Caron, M., 1985. Cretaceous planktonic foraminifera. In Bolli, H. M., Saunders, J. B., and Perch-Nielsen, K. (Eds.), Plankton Stratigraphy: Cambridge (Cambridge Univ. Press), 17-86.

Caulet, J.-P., 1985. Radiolarians from the southwest Pacific. In Kennett, J. P., von der Borch, C. C., et al., Init. Repts. DSDP, 90: Washington (U.S. Govt. Printing Office), 835-861.

1986. A refined radiolarian biostratigraphy for the Pleistocene of the temperate Indian Ocean. Mar. Micropaleontol., 11:217229.

Chen, P. H., 1975. Antarctic radiolaria. In Hayes, D. E., Frakes, L. A., et al., Init. Repts. DSDP, 28: Washington (U.S. Govt. Printing Office), 407-474.

Ciesielski, P. F., 1983. The Neogene and Quaternary diatom biostratigraphy of subantarctic sediments, Deep Sea Drilling Project Leg 71. In Ludwig, W. J., Krasheninnikov, V. A., et al., Init. Repts. DSDP, 71 (Pt. 2): Washington (U.S. Govt. Printing Office), 635-666.

Ciesielski, P. F., Kristoffersen, Y., et al., 1988. Proc. ODP, Init. Repts., 114: College Station, TX (Ocean Drilling Program).

DePaolo, D. J., 1986. Detailed record of the Neogene Sr isotopic evolution of seawater from DSDP Site 590B. Geology, 14:103-106.

Fröhlich, F., and Wicquart, E., 1989. Upper Cretaceous and Paleogene sediments from the northern Kerguelen Plateau. Geo-Mar. Lett., 9: 127-133.

Gersonde, R., Abelmann, A., Burckle, L. H., Hamilton, N., Lazarus, D., McCartney, K., O'Brien, P., Speiß, V., and Wise, S. W., Jr., 
1990. Biostratigraphic synthesis of Neogene siliceous microfossils from the Antarctic Ocean, ODP Leg 113 (Weddell Sea). In Barker, P. F., Kennett, J. P., et al., Proc. ODP, Sci. Results, 113: College Station, TX (Ocean Drilling Program), 915-936.

Gersonde, R., and Burckle, L. H., 1990. Neogene diatom biostratigraphy of ODP Leg 113, Weddell Sea (Antarctic Ocean). In Barker, P. F., Kennett, J. P., et al., Proc. ODP, Sci. Results, 113: College Station, TX (Ocean Drilling Program), 761-789.

Gordon, A. L., 1971. Oceanography of Antarctic waters. In Reid, J. L. (Ed.), Antarctic Oceanology I. Am. Geophys. Union, Antarct. Res. Ser., 15:169-203.

Harwood, D. M., 1989. Siliceous microfossils. In Barrett, P. J. (Ed.), Antarctic Cenozoic History from the CIROS-1 Drillhole, McMurdo Sound. D.S.I.R. Bulletin, 245:67-97.

Harwood, D. M., Barrett, P. J., Edwards, A. R., Rieck, H. J., and Webb, P.-N., 1989. Biostratigraphy and chronology. In Barrett, P. J. (Ed.), Antarctic Cenozoic History from the CIROS-1 Drillhole, McMurdo Sound. D.S.I.R. Bulletin, 245:231-239.

Hess, J., Stott, L. D., Bender, M. L., Kennett, J. P., and Schilling, J.-G., 1990. The Oligocene marine microfossil record: age assessments using strontium isotopes. Paleoceanography, 4:655-679.

Huber, B. T., 1990. Maestrichtian planktonic foraminifer biostratigraphy of the Maud Rise (Weddell Sea, Antaretica): ODP Leg 113 Holes 689B and 690C. In Barker, P. F., Kennett, J. P., et al., Proc. ODP, Sci. Results, 113: College Station, TX (Ocean Drilling Program), 489-513

Keller, G., and Barron, J. A., 1987. Paleodepth distribution of Neogene deep-sea hiatuses. Paleoceanography, 2:697-713.

Keller, G., Herbert, T., Dorsey, R., D'Hondt, S., Johnsson, M., and Chi, W. R., 1987. Global distribution of late Paleogene hiatuses. Geology, 15:199-203.

Lazarus, D., 1990. Middle Miocene to Recent radiolarians from the Weddell Sea, Antarctica, ODP Leg 113. In Barker, P. F., Kennett, J. P., et al., Proc. ODP, Sci. Results, 113: College Station, TX (Ocean Drilling Program), 709-727

in press. Antarctic Neogene radiolarians from the Kerguelen Plateau, ODP Legs 119 and 120. In Schlich, R., Wise, S. W., Jr., et al., Proc. ODP, Sci. Results, 120: College Station, TX (Ocean Drilling Program).

Mankinen, E. A., and Cox, A., 1988. Paleomagnetic investigation of some volcanic rocks from the McMurdo volcanic province, Antarctica. J. Geophys. Res., 93:11599-11612.

McCollum, D. W., 1975. Diatom stratigraphy of the southern ocean. In Hayes, D. E., Frakes, L. A., et al., Init. Repts., DSDP, 28: Washington (U.S. Govt. Printing Office), 515-571.

Miller, K. G., Feigenson, M. D., Kent, D. V., and Olsson, R. K., 1988. Upper Eocene to Oligocene isotope $\left({ }^{87} \mathrm{Sr} /{ }^{86} \mathrm{Sr}, \delta^{18} \mathrm{O}, \delta^{13} \mathrm{C}\right)$ standard section, Deep Sea Drilling Project Site 522. Paleoceanography, 3: 223-233.

Monechi, S., Bleil, U., and Backman, J., 1985. Magnetobiochronology of Late Cretaceous-Paleogene and late Cenozoic pelagic sedimentary sequences from the northwest Pacific, Deep Sea Drilling Project, Leg 86, Site 577. In Heath, G. R., Burckle, L. H., et al., Init. Repts. DSDP, 86: Washington (U.S. Govt. Printing Office), 787-798.
Monechi, S., and Thierstein, H. R., 1985. Late Cretaceous-Eocene nannofossil and magnetostratigraphic correlations near Gubbio, Italy. Mar. Micropaleontol., 9:419-440.

Okada, H., and Bukry, D., 1980. Supplementary modification and introduction of code numbers to the low-latitude coccolith biostratigraphic zonation (Bukry, 1973; 1975). Mar. Micropaleontol., 5:321325.

Roth, P. H., 1978. Cretaceous nannoplankton biostratigraphy and oceanography of the northwest Atlantic Ocean. In Benson, W. E., Sheridan, R. E., et al., Init. Repts., DSDP, 44: Washington (U.S. Govt. Printing Office), 731-761.

Sanfilippo, A., and Riedel, W. R., 1985. Cretaceous radiolaria. In Bolli, H. M., Saunders, J. B., and Perch-Nielsen, K. (Eds.), Plankton Stratigraphy: Cambridge (Cambridge Univ. Press), 631-712.

Shackleton, N. J., Moore, T. C., Jr., Rabinowitz, P. D., Boersma, A., Borella, P. E., Chave, A. D., Duee, G., Futterer, D., Jiang, M.-J., Kleinert, K., Lever, A., Manivit, H., O'Connell, S., and Richardson, S. H., 1984. Accumulation rates in Leg 74 sediments. In Moore, T. C., Jr., Rabinowitz, P. D., et al., Init. Repts, DSDP, 74: Washington (U.S. Govt. Printing Office), 621-637.

Stott, L. D., and Kennett, J. P., 1990. Antarctic Paleogene planktonic foraminifer biostratigraphy: ODP Sites 689 and 690. In Barker, P. F., Kennett, J. P., et al., Proc. ODP, Sci. Results, 113: College Station, TX (Ocean Drilling Program), 549-569.

Tauxe, L., Tucker, P., Petersen, N. P., and LaBrecque, J. L., 1984. Magnetostratigraphy of Leg 73 sediments. In Hsü, K. J., LaBrecque, J. L., et al., Init. Repts. DSDP, 73: Washington (U.S. Govt. Printing Office), 609-621.

Thomas, E., Barrera, E., Hamilton, N., Huber, B. T., Kennett, J. P., O'Connell, S., Pospichal, J. J., Speiß, V., Stott, L. D., Wei, W., and Wise, S. W., Jr., 1990. Upper Cretaceous-Paleogene stratigraphy of Sites 689 and 690, Maud Rise (Antarctica). In Barker, P. F., Kennett, J. P., et al., Proc. ODP, Sci. Results, 113: College Station, TX (Ocean Drilling Program), 901-914.

Weaver, F. M., 1983. Cenozoic radiolarians from the southwest Atlantic, Falkland Plateau region, Deep Sea Drilling Project Leg 71. In Ludwig, W. J., Krasheninnikov, V. A., et al., Init. Repts, DSDP, 71, (Pt. 2): Washington (U.S. Govt. Printing Office), 667-686.

Weaver, F. M., and Gombos, A. M., 1981. Southern high-latitude diatom biostratigraphy. In Warme, T. E., Douglas, R. G., and Winterer, E. L. (Eds.), The Deep Sea Drilling Project: A Decade of Progress: Spec. Publ. Soc. Econ. Paleontol. Mineral., 32:445-470.

Wei, W., and Wise, S. W., Jr., 1989. Paleogene calcareous nannofossil magnetobiochronology: results from South Atlantic DSDP Site 516. Mar. Micropaleontol.,14:119-152.

1990. Middle Eocene to Pleistocene calcareous nannofossils recovered by Ocean Drilling Program Leg 113 in the Weddell Sea. In Barker, P. F., Kennett, J. P., et al., Proc. ODP, Sci. Results, 113: College Station, TX (Ocean Drilling Program), 639-666.

Date of initial receipt: 5 March 1990

Date of acceptance: 18 June 1990

Ms 119B-188 